

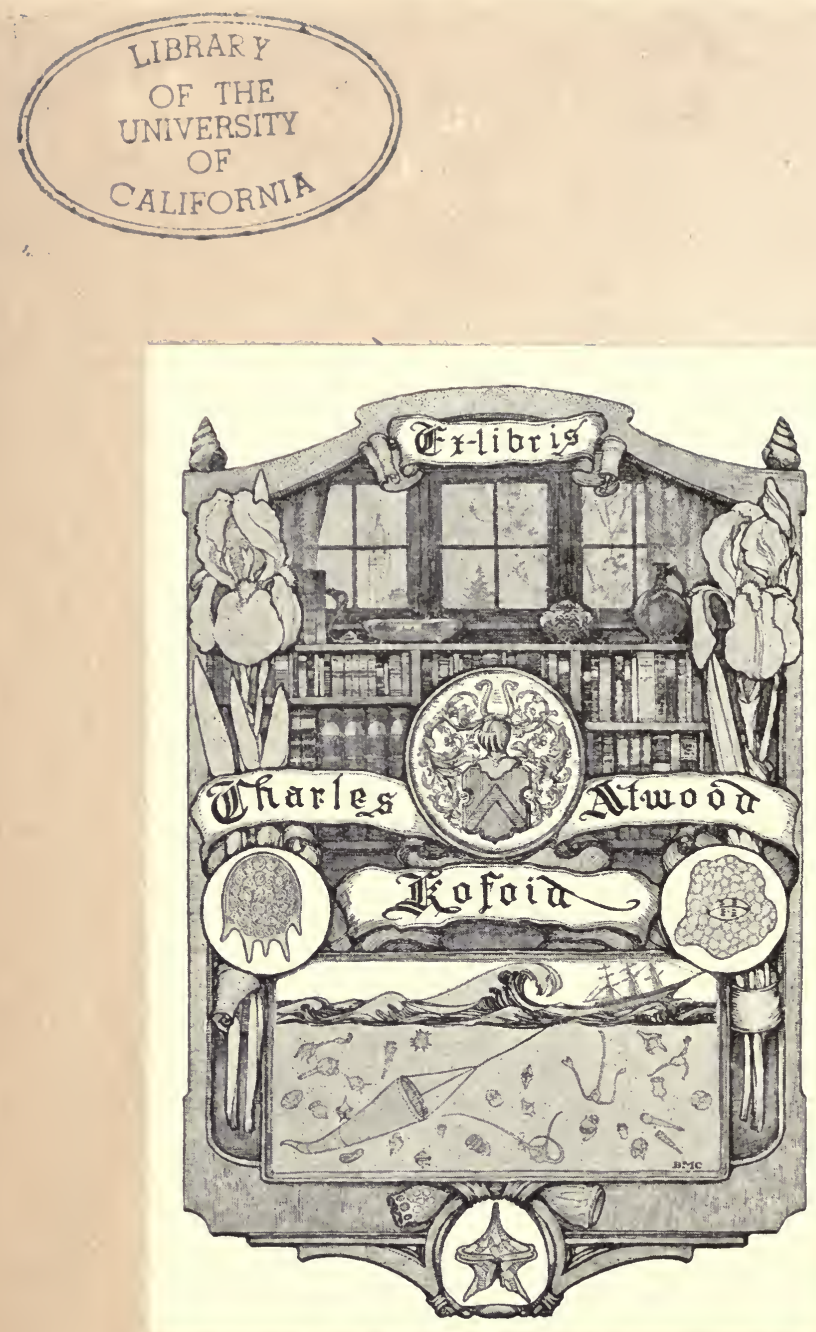






\section{Breeding and Developing The Trotter}








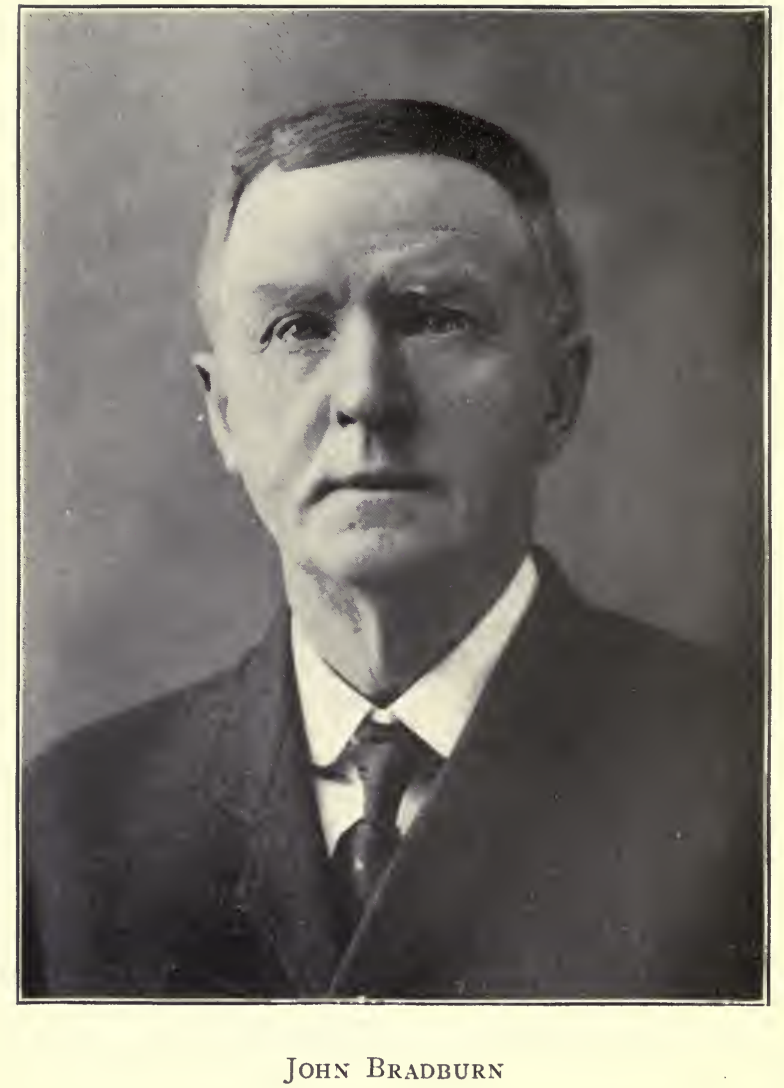




\title{
Breeding and
}

\section{Developing}

\section{The Trotter}

\section{By JOHN BRADBURN}

For Twenty-five Years Superintendent of Village Farm East Aurora, New York

\section{ILLUSTRATED}

\author{
Edited by Arthur C. Thomas \\ ASSOCIATE EDITOR \\ American Horse Breeder
}

American Horse Breeder Publishing Company Boston, Massachusetts 
Copyright, I 906

By Ambrican Horse Breeder

Publishing Company

PRESS OF

MURRAY AND EMERY COMPANY' BOSTON, MASS. 


\section{PREFACE}

Breeders of trotting stock have for a long time felt the need of a reliable work on the proper selection of mares for brood purposes, giving in detail the care and treatment that they should receive in order to put them in the best possible condition to impart vigor to their offspring and also transmit to their foals their own superior qualities in the highest possible degree. They have wanted a work which will also give minute instructions in regard to the feed, exercise and care of stallions at all seasons of the year, particularly just before and during the service season, and in addition to the above, will tell how to care for the foal and its dam from the time the youngster is conceived until he or she is in fit condition to place in the hands of an expert trainer to be conditioned for the rich futurities.

Every one interested in breeding trotting stock, and especially all those just entering upon the business, will admit that such a work, coming from a man who has had years of successful experience in the business and knows every detail of it thoroughly, must be of inestimable value.

Very few men are qualified to furnish the matter for such a work. We have never yet seen a book of that kind, and do not know that one has yet been published that has come from 


\section{PREFACE}

a man who has been instrumental in breeding extreme speed of the 2.ro and world's recordbreaking sort.

Judging by the successful experience in caring for the sires and dams of 2.10 performers, also in the care and management of the 2.ro performers themselves during the early period of their existence, there is no man living who is so competent to furnish the materials of a work of this kind as Mr. John Bradburn, who was the superintendent of the noted Village Farm establishment from a period long before a 2.15 performer was ever bred there until the dispersal sale of the Village Farm stock.

At the earnest and persistent solicitation of many of his intimate friends, and also of many practical breeders who were not personally acquainted with him, but who knew him through the reputation that he had made as the successful manager of the renowned Village Farm establishment, Mr. Bradburn was finally persuaded to put on paper for the benefit of trotting-horse breeders the knowledge that he has gained in the breeding and care of choice race-winning trotting stock during those many years of experience.

The information contained within these covers will be of great service to all who are breeding and raising or have the care and management of trotting stock or light-harness horses of any kind. It will be worth many times its cost to every one who owns a good brood-mare or stallion, because it is a book of valuable facts. 


\section{PREFACE}

It may also be read with interest and profit by the proprietors and managers of the most extensive breeding establishments, men who have had years of experience in the business, as well as by those who breed and raise but one or two foals a year. To those who are about to establish farms devoted to the breeding of trotters, or are just starting in the business on a limited scale, it will prove of immense value.

\section{THE PUBLISHERS.}

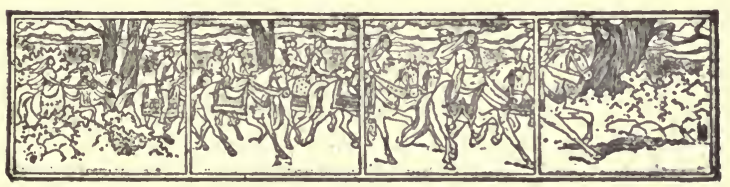





\section{CONTENTS}

Pages

Chapter One. Personal ........... I-20

"Who Is He?"

My First Horse

My First Brood-Mare

Jane Brown

Pelham Tartar Jr.

My First Stallion

A Mare that Hambletonian did not Cover

First Day on a Race-Track

Three-Card Monte

A Full-Fledged Farmer

A Hotel Keeper and Public Trainer

A Liveryman

My First Race

Roading It

Ice Racing

On to Buffalo

"Derricked"

Back to Buffalo

Superintendent at Village Farm

A Betting System

Village Farm Graduates

Ideal Stock Farm

Chapter Two. The Village Farm Theory of Breeding .......... 2I -48

"World's Greatest Trotting Nursery"

Mr. Hamlin's First Mare

Hamlin Patchen

Mr. Hamlin's First Team

Golddust

Woful

Mermaid and Dictator Maid

Weeding Out

Nettie Murphy

Minnequa Maid

Purchasing a Premier

More Purchases

Estabella 


\section{CONTENTS}

Almont Jr.

Mambrino King

"The Handsomest Horse in the World"

Chimes

Golden Gateway

Rex Americus

Athanio

Direct $\mathrm{Hal}$

The First Catalogue

"Mr. Hamlin's Theory of Breeding "

The Brood-Mare's Importance

Beauty and Speed

Developed Sires

A Challenge

Selecting Brood-Mares

A Prediction

"The Passing of Village Farm"

Chapter Three. Founding a Stock Farm

Location

Soil

Water

Size of Farm

Acres of Land per Head

The Track

Rules for Laying Out Track

The Cinder Track

Paddocks

Fencing

Stables

Main Barn

Water in Paddock

Brood-Mare Shed

The Farm Superintendent

Chapter Four. The Stallion.........

Purchasing a Premier

Over-Developed Sires

Concrete Examples

Almont Jr.

Almonarch

Natural Speed

Blood Lines

The Stallion's Sire 


\section{CONTENTS}

The Stallion's Dam

Pages

The Stallion's Individuality

My Ideal Stallion

Trotter vs. Pacer

Shall the Stallion be Raced?

The Stud Season

Care of Stallion

Feeding

Covering the Mare

The Breeding Pen

Trial Sheet and Stud Book

Chapter Five. The Brood-Mare ....... 83-100

Best Way to Purchase Mares

The Ideal Brood-Mare

Pedigree

Care

Preparing for the Foal

Care of Mare and Colt After Foaling

Breeding the Mare

Care of Mare and Colt in the Pasture

Weaning the Colt

Mare on Winter Diet

Age at which to Breed

Developed Mares

Inbreeding

Selecting a Mate

First Impressions

Importance of Natural Speed

Chapter Six. The Weanling and Yearling $\ldots \ldots \ldots \ldots \ldots \ldots \ldots$ IOI-IO8

Halter-Breaking

Breaking to Bit

Beside a Lead Pony

Ground-Breaking

Hooking to Cart

Shoeing

Developing Muscles and Speed

"Dr. Green"
A Futurity Candidate
Feeding
The Yearling 


\section{CONTENTS}

Chapter Seven. The Two-Year-Old and

Older ................ IO9-I I4

Winter Work

Spring Work

Summer Work

Turning Over to a Trainer

Use of Bandages and $\mathrm{W}$ ashes

Packing of Feet

Aged Horses

Chapter Eight. Preparing for the Sales and the Show Rings.......... II 5-I I8

Avoid Over-Production

The Best Age at which to Sell

Preparing for Sales

Culls

Show Horses

Preparing for Shows

Incidentals

Chapter Nine. Management of a Stock

Farm ................ II I9-I 29

Business Principles

The Superintendent

The Trainer

Grooms

Sources of Revenue

Advertising and Catalogues

Breeding Records

Causes of Failures

Sources of Waste

Chapter Ten. Care of the Feet and Teeth ............. I30-I34

Care of Feet

Young Colts

Corns

The Perfect Hoof

Ring-Bone

After the Races

Thrush

Care of the Teeth 


\section{CONTENTS}

Chapter Eleven. Some Ailments and

Disorders.............. I 35 -I 43

Treatment of Barren Mares

Sweat Box

Treatment for Pneumonia

Distemper

When Stallions are Dull

Masturbation

Navel Trouble

Diarrhea.

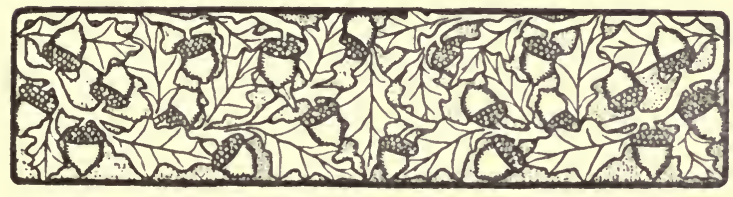





\section{ILLUSTRATIONS}

John Bradburn . . . . Frontispiece The Abbot (2.03 1/4) . . . opposite page II Nettie King (2.201/2) . . . opposite page 27 Prince Ideal . . . . . opposite page 43 Main Barn at Ideal Stock Farm opposite page 75 



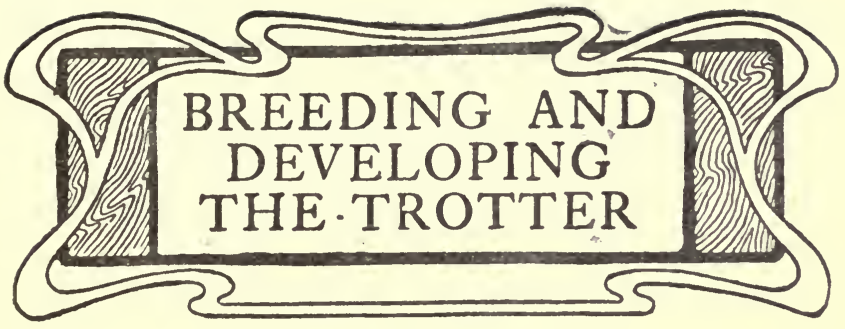

\section{Chapter One}

\section{PERSONAL}

"Who Is He?" - My First Horse. - My First BroodMare. - Jane Brown. - Pelham Tartar Jr. - My First Stallion. - A Mare that Hambletonian did not Cover. - First Day on a Race Track. - Three Card Monte. - A Full Fledged Farmer. - A Hotel Keeper and Public Trainer. A Liveryman.-My First Race. - Roading It. - Ice Racing.On to Buffalo. - "Derricked." - Back to Buffalo. - Superintendent at Village Farm. - A Betting System. - Village Farm Graduates. - Ideal Stock Farm.

\section{"WHO IS HE ?"}

COME of my readers will ask the questions, $\infty$ "Who is this man Bradburn? What experience has he had? Does he know what he is talking about?"

These questions are pertinent. It is not enough for me to say that I have had experience, covering the points on which I give advice,-I must explain just what that experience was and how it was obtained. Here goes for some of the dark secrets of my past. 
I was born in St. Catherines, Ontario, Canada, in I842. My father died when I was six years old and, as it was necessary for me to do something to support myself, I went on the farm of George Oile, and he, after a fashion, adopted me. I was then about nine years old. Mr. Oile's farm was six miles from St. Catherines and twelve miles from Niagara Falls.

\section{MY FIRST HORSE.}

I was about thirteen years when I came into possession of my first horse, a gray colt, which Mr. Oile gave me. It did not have a pedigree, in fact, not much attention was paid to pedigrees in those days. The colt was what would now be called a nice general-purpose horse. Like all boys in similar positions I thought the colt was the greatest one in the world. I broke him and drove him till he was four years old and sold him for one hundred and fifty dollars, which was then a lot of money for a colt, especially to a boy.

I was now seventeen years old and about this time I commenced working Mr. Oile's farm on shares. I gave considerable attention to the breeding of thoroughbred short-horn cattle and long-wooled Leicester sheep and this knowledge was afterwards of great service to me in the mating of trotters.

As I have mentioned, little attention was then paid to the pedigrees of trotters, but, as I liked horses, I kept posted on such matters and before long became quite celebrated, locally, as a sup- 


\section{BREEDING THE TROTTER}

posed pedigree expert. Wilkes' Spirit of the Times was the great trotting authority in the old days and all bets went by Wilkes, were he right or wrong. In time I came to be known as "Walking Wilkes," just as some men are now called "a walking encyclopædia."

\section{MY FIRST BROOD-MARE.}

The one hundred and fifty dollars obtained by the sale of my colt went to start a bank account to which I added "chicken money" from time to time. Before very long I saw a gray mare I liked and I bought her for one hundred and twenty-five dollars. She was said to be by Grey Messenger, he reputed to be a grandson of Sherman Morgan. The Messenger horse is known in the Year Book as Hoagland's Grey Messenger I55. He had a record of 2.43 and afterwards went to New Jersey.

My mare was carrying a foal by Grantham Chief 685 I, a son of Royal George 9. She dropped a gray filly which developed into a very handsome mare, but as a three-year-old she jumped into a hay rack. I was a pretty sick chap when I went into her stall and found pieces of wood sticking into her side. Of course she had to be killed.

JANE BROWN.

After the mare produced the Grantham Chief foal I bred her to Prince of Wales, a son of Royal George, owned by Alvah Ditrich of St. Catherines. I paid ffteen dollars service fee and the 


\section{BREEDING THE TROTTER}

country people called me crazy. Farm mares were usually sent to five-dollar stallions. I always liked to breed to the best stallion I could afford. There was considerable rivalry between Prince of Wales and Grantham Chief, which resulted in several match races, but the former was considered the best in the country. My mare foaled a black filly by Prince of Wales. She is known in the books as Jane Brown. As a threeyear-old I sold her to James Haney of St. Johns, Ontario, for three hundred and fifty dollars. I had trained her to step around a 3.Io clip. The second or third time Haney took her to a track she trotted a mile in three minutes. Haney sold her to William H. Saunders, one of the famous old-time horsemen, and father of George Saunders, a well-known driver of to-day. Saunders trained Jane Brown some, but she went wrong and he bred her to George Wilkes (2.22). The produce was Young Wilkes $(2.281 / 4)$, the sire of thirty-two in 2.30 .

\section{PELHAM TARTAR JR.}

After foaling Jane Brown I bred my mare to Pelham Tartar, a seal-brown stallion, by Toronto Chief, owned by James Cairns and John Fralick, livery stable keepers of St. Catherines. Pelham Tartar's service fee was twenty dollars and when I paid that the neighbors gave up all hopes for my sanity. My good opinion of the horse was verified when Chandler $\mathrm{J}$. Wells bought him for five thousand dollars. His purchase was the sen- 


\section{BREEDING THE TROTTER}

sation of that part of the country. My mare foaled a gray colt, which I called Pelham Tartar Jr. I trained him on "the straight road" which ran past the farm and as a three-year-old showed him at the fairs at Pelham and Grantham, in the classes for style and speed, best three-year-olds to harness. I won both. After this I matched him against a three-year-old owned by Elias Paterson and Thomas Calbert for one hundred dollars, so you see my sporting blood cropped out young. The match was trotted over the St. Catherines track, best three in five, pay or play. As my opponents were all older men I secured "Pete" Curran, a famous local driver, to drive my colt. Later, when I took to the sulky myself, I often drove races for him. Pelham Tartar Jr. won the match in three straight heats, best time 3.03 . After the race I sold my colt to James Haney, who had purchased Jane Brown, for fifteen hundred dollars, and, of course, I thought I had more money than any young man in the world.

\section{MY FIRST STALLION.}

After my mare had produced Pelham Tartar Jr. I bred her to Tom Kimball, a chestnut stallion, the sire of Lady Hill (2.35), and got a dark irongray colt, which I called Tom Kimball Jr. I afterwards purchased his sire for four hundred dollars and made two seasons with him in Pelham township. Tom Kimball Jr. made a nice colt. I did not have time to train him, and as no other trainer would do I gelded him as a four-year-old 


\section{BREEDING THE TROTTER}

and sold him to John Scott of Galt, Ontario, for four hundred dollars.

The next season or two my mare missed but afterwards produced a gray filly and a gray colt by Tom Kimball. The latter I sold, for a road horse, to William Hamlin.

A MARE THAT HAMBLETONIAN DID NOT COVER.

To show that I always believed in breeding mares to the best stallion I could afford I might mention that after selling Pelham Tartar Jr. for fifteen hundred dollars, at which time I had about twenty-two hundred dollars in the bank, I decided to breed my mare to Rysdyk's Hambletonian, standing at five hundred dollars. I found that the freight and keep of mare would cost an additional one hundred and fifty dollars. This was a lot of money for a youngster to put into a foal, but Hambletonian at that time was on top, and I wanted some of his blood. No sooner had I made known my intention of breeding my mare to Rysdyk's Hambletonian than George Oile and the neighbors raised a terrible howl, pronouncing me " horse foolish," and some of them went so far as to call me insane,-a monomaniac would be the term nowadays. Public sentiment was so strong against me that I did not send the mare. I consider this one of the mistakes of my life.

\section{FIRST DAY ON A RACE TRACK.}

One of the memorable events of my youth was my first day on a race track, which was also the 


\section{BREEDING THE TROTTER}

first time I ever saw a horse trot faster than 2.30 . It was the day Flora Temple trotted a match against Ike Cook over the St. Catherines track. By referring to Chester I find the date to be November 5, I859,-I was then seventeen years old. If I remember rightly I should have been in school that day. It was a glad day for me, but a sad one for Joshua Birch, a friend of mine. He had come to town with a load of wheat for his father, had sold the wheat, and was on the point of starting for home when I saw him. He naturally asked me where I was going.

"I'm going to see the great trotter, Flora Temple," I said. "Come along."

" Can't do it," he said. "I've got to get home."

" Come along," I insisted. " I'll pay your way and pay to have your horses put up."

\section{THREE CARD MONTE.}

I had a few dollars in my pocket and felt rich. With a little persuasion, Joshua was induced to accompany me. After eating dinner we went out to the race track. A few hundred feet from the gate was a ring of people. We went up and found a three card monte game in operation. It was the first one we had ever seen. Joshua kept his eyes on the card several minutes and then turned to me.

"I'm going to bet him I can spot the card," he whispered.

"Better not," I replied. "I've read about such tricks. They're crooked. Those fellows wouldn't do it for the fun of the thing, you know." 


\section{BREEDING THE TROTTER}

I could not restrain him. He pulled out the money he had received for his father's wheat and before he stopped he had lost ten dollars, and feit pretty sore.

Before reaching the entrance to the race track we sighted another game. Here Joshua decided to try to get even but lost twenty dollars more. He was a pretty sick chap now, and almost on the verge of tears.

We walked about the grounds a while. After taking in the sights I suggested to Joshua that we walk to the stables to see them hitching Flora Temple. He said he did not care to, but told me to go on and promised to meet me later.

It was some time before I had seen enough of Flora Temple, and when I returned to meet Joshua I found him very much "down in the mouth." He had tackled the card game once more and had lost all his father's wheat money, about sixty-five dollars in all. He wanted me to go home with him, but my fun was just commencing, so I stayed. His afternoon's pleasure was spoiled and he left. His father was not hard on him, knowing that the experience had taught Joshua a lesson that can be taken to heart by all young men. Flora Temple beat Ike Cook in $2.35,2.29,2.27$.

\section{A FULL-FLEDGED FARMER.}

As stated before, it was about this time I took Mr. Oile's farm to work on shares. He gave me a third of all stock and crops and the keep of my 


\section{BREEDING THE TROTTER}

mare and her produce. I did pretty well on the farm and dabbled with horses once in a while. One deal in particular I recall. I bought a green colt by Prince of Wales, a dark bay, with strip in face, for sixty dollars. His dam was by a runner called Grantham. I trained the colt on the straight road and sold him after three months to John Fralick for four hundred and fifty dollars. This established for me a local reputation as a great colt trainer and one of those "hurrah boys."

\section{A HOTEL KEEPER AND PUBLIC TRAINER.}

In 1870 I tired of farming and, as I had eight thousand dollars in the bank, I purchased a hotel in Welland, Ontario. Shortly afterwards I entered the state of matrimony and married Miss Sarah Davis.

In addition to running the hotel I trained a public stable of horses.

Pelham Tartar Jr. had not been going well for James Haney and, as I thought I could get him straightened out, I bought him back for six hundred dollars. The horse had been overtrained and was low in flesh. I built him up within six or eight weeks and started training him over. In a workout shortly afterwards Pelham Tartar Jr. trotted a mile for me in 2.40 and I sold him once more to Mr. Haney for twelve hundred dollars. He did not improve as he should and as he was a goodsized horse and well liked locally Mr. Haney placed him in the stud. 


\section{BREEDING THE TROTTER}

\section{A LIVERYMAN.}

In 1872 I sold out my hotel and purchased a brick block in which were a store, billiard room and livery stable. This business kept me busy for the next three years when I sold out and moved to St. Catherines. In the spring of 1875 I ran a billiard room of eight tables, but I did not like the business. It was too confining.

I might say right here that by this time I had "gone broke." When the Canadian Southern Railroad came through and spoiled my livery trade I foolishly hung on till I had sunk a great deal of money in the business. Four horses were doing my work while formerly I needed twenty. To cap it all I went on a bond for several thousand dollars and had to make good.

\section{MY FIRST RACE.}

I might previously have described the first race in which $I$ ever drove. This was a match race between a three-year-old by Grantham Chief, which I had purchased for one hundred dollars, and another local horse of the same age. The match was for seventy-five dollars a side. I won in one-two-three order, time about 3.I 5, 3.20, 3.25. The same party asked for a return match in two weeks, for fifty dollars a side, and this I also won in three straight heats.

$$
\text { ROADING IT. }
$$

One of my first campaigns was with Pelham Tartar Jr. and a little running horse called Charles 


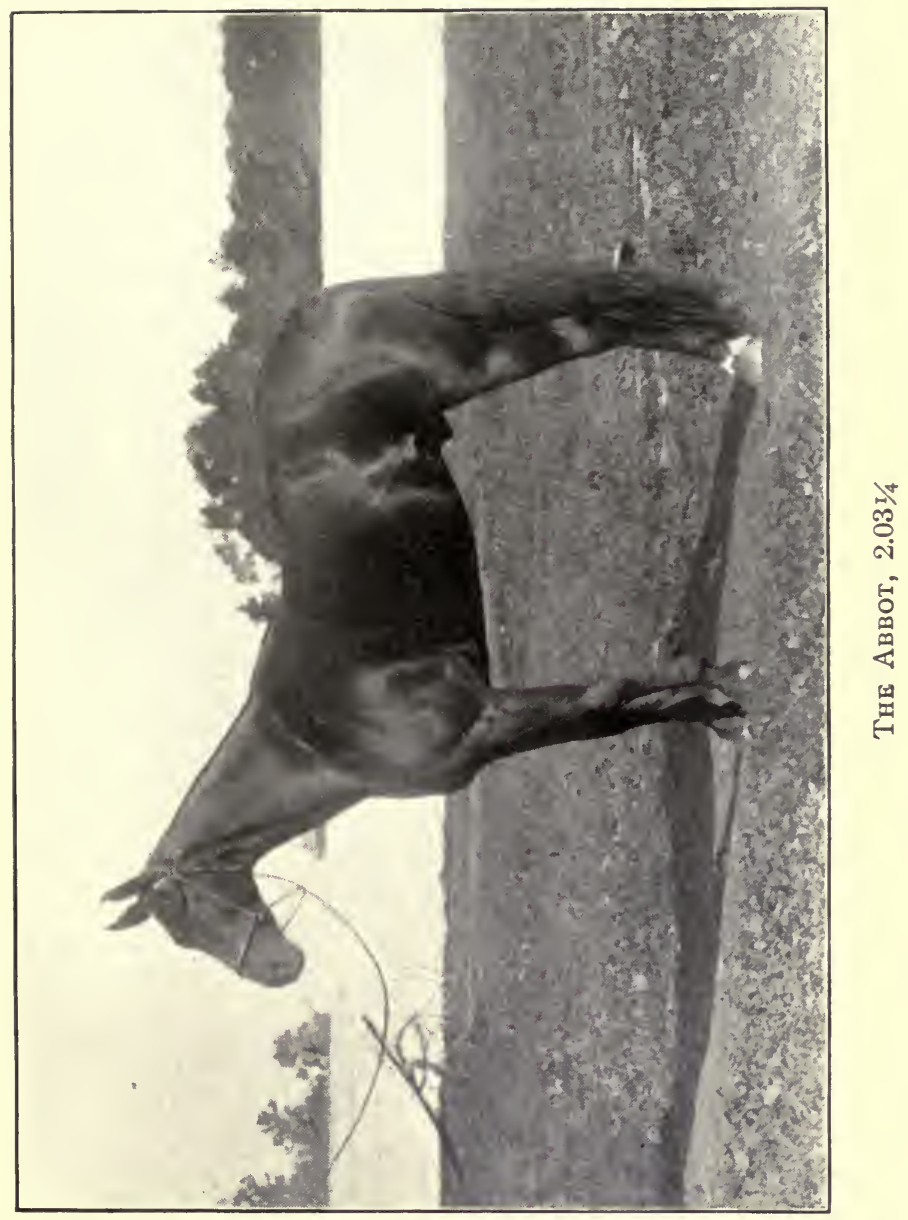





\section{BREEDING THE TROTTER}

Stewart. I traveled over the road from town to town, as we all did in those days, racing at Hamilton, Galt, Mitchell and Toronto. I had no success : the horses took sick, the weather was hot, and the runner lost his speed, so we came home, making a very sorry-looking spectacle.

In 1876 I had fair success with my public stable. In my string were Lady Hill, Dominion Boy, Brown Dick, Douglas, Quaker Boy and Lady $\mathrm{H}$.

One of the noted races of those days in which I drove was trotted on September I5, I876, at Woodbine Track, Toronto, Ontario. It was one of the greatest betting races ever seen on any race track in Ontario, before or since. There was in the neighborhood of forty or fifty thousand dollars in the box. St. Patrick and Lady Hill were about equally well liked, the selling on them switching from one hundred-eighty to ninetyone hundred. The field-Gray Eddy, William W. and Stayer-brought little. I won the first heat with Lady Hill, the time hung out being 2.35. In reality it was $2.291 / 2$. St. Patrick won the next heat in $2.35 \frac{1}{4}$, really $2.291 / 4$, and the third heat in 2.35 , really 2.30 . After this he tired and I won the fourth heat in 2.40 (2.3I). On account of darkness the race was postponed. It commenced raining that night and rained all the next day. The following day was Sunday. On Monday we trotted the race off. St. Patrick won in the announced time of 2.35 , which was $2.29 \frac{1}{2}$ to the best of my recollection. 


\section{BREEDING THE TROTTER}

After this race I roaded my horses to Oshawa, Ontario, twenty-three or twenty-four miles north of Toronto. It was the first meeting over a new track. I won the 3.00 and 2.50 trots with Douglas, and the 2.34 and free-for-all trots with Lady Hill, which cleaned up the card with the exception of the county race.

\section{ICE RACING.}

In the winter of $1876, \mathrm{Mr}$. Eli Gregory gave me the bay gelding Alexander, by Bett's St. Lawrence, dam by Pelham Tartar, to get ready for the ice races. I also had the gray gelding Monk Boy. My first start on the ice was at Dunville, Ontario, the last week in December. I also raced at Brantford, St. Catherines, Toronto, Ottawa, and Montreal, shipping home about April I5. Monk Boy won every race in which he started; Alexander, every race but one, winning fourteen out of fifteen starts. He started twice at Dunville, Brantford and St. Catherines and three times at Toronto, Ottawa and Montreal. He won two heats and second money in his losing race. It was a very successful season. Alexander was afterwards sold to John Reardon of St. Catherines for one thousand nine hundred and seventy-five dollars. $\mathrm{He}$ was a very peculiar horse, in that he would always take the colic if fed a bran mash.

ON TO BUFFALO.

In the spring of 1877 I moved to the Buffalo (N. Y.) Driving Park and opened a public train- 
ing stable. It was in this year I first met Mr. C. J. Hamlin, in whose employ I was afterwards destined to be for some twenty-five years. He was a regular visitor to the track. During 1877 I campaigned Monk Boy, Jim Ash, Black Bear, Gray Salem, etc.

In 1878 I campaigned Alexander and two others through Canada, Michigan and Northern New York.

\section{"DERRICKED."}

In 1878 occurred the first and only time I was taken out of the sulky. On September I 2, I was racing Jim White (2.3I) at Elmira, N. Y. In the same race were Nell Parks, Monk Boy, Helen R., Lady Wonder and Elliot. Elliot won the first heat. Lady Wonder won the next heat and distanced Elliot. I had given the owner of Jim White some of my money to play on the horse, so after the second heat I went to him and said : "I think we stand a chance to win." " All right," he replied, "your money is down." The next heat I won and Lady Wonder was distanced. I won the fourth heat also. Then the owner came to me and told me not to win another heat till instructed. I was between the devil and deep sea. My financial condition was such that I could not afford to antagonize the owner. I had no religious compunction against dropping a heat now and then, if it would help my horse to win, but in this instance the field had narrowed down. My horse outclassed everything, and could win 


\section{BREEDING THE TROTTER}

easily. I asked the owner why it was necessary to drop the heat. He then confessed that he had played against his gelding all the time and had played my money also. I informed him that it was a nice time to tell me about it and advised him to play off as much of our money as he could and let me win. He would not consent to this so I dropped the next heat. It was won by Nelly Parks. The race was then postponed and only two of us were left to finish. That evening I was called to the telephone. It was about the first time I had used one. A friend down town informed me that it was reported I would be taken out of the sulky the next day. It did not surprise me any,-in fact was just what I expected. I now figured out that if I wished to protect myself and not stand liable to expulsion I would have to see to it that the gelding lost. I sat up almost all night whittling a pair of wooden toe-weights, which I colored to resemble the metal ones. These weighed one and one half ounces, whereas the horse had been using six-ounce weights. Sure enough the next day, when Jim White and Nelly Parks came out to trot off the race, the judges took me down and put up Jimmy Goldsmith. Jim White was, of course, unsteady and they scored seventeen times. I was called to the stand. The judges told me to stay near and added that if the horses did not get the word on the next score I would be put back, as they thought I might make a better showing. I had previously promised to try to win if they would 


\section{BREEDING THE TROTTER}

let me drive. In the next score Goldsmith took the gelding way back. Jim White stayed on his feet but was far in the rear. Goldsmith nodded for the word and it was given. The horse made a double break on the first turn and I gave a sigh of relief. When he got settled at the quarter pole, Nelly Parks was entering the head of the stretch the first time round. Jim White set sail and trotted so much faster than she that he easily won in $2.371 / 2$, which was five seconds faster than any heat in the race. He trotted the last half in I.101/2. The judges awarded Goldsmith fifty dollars of the winnings for driving and mercifully let me off with a lecture. No judge ever had occasion thereafter to take me out of the sulky. I had had enough of that sort of business.

This is one instance which upholds a theory of mine that more drivers are made to do crooked things by their employers than do so on their own account. And just here, one word of advice to all young trainers: Win by all means if you can.

\section{BACK TO BUFFALO.}

In 1879 I returned to Buffalo and opened a public stable. I had sixteen horses, including Monk Boy, Gray Salem and Lady Upton. That fall Mr. C. J. Hamlin placed in my stable Rockey, Almont Jr. and Knox. In February, I880, I engaged to go to East Aurora, N. Y., to take charge of Mr. Hamlin's horses.

At this point mention might be made of a race which did more to bring me close to Mr. Hamlin 


\section{BREEDING THE TROTTER}

than any one thing. This was the race of August 7, 1879, in which were entered Kate Hall, Daciana Gloster, Lady Upton, Argonaut, Nigger Baby and Lady B. I was second the first and second heats with Lady Upton and thought I stood a chance to win, but the owner did not want me to so I asked him to drive. After the fifth heat my mare was ruled out and the race postponed on account of darkness. The judges had not been satisfied with the way McLaughlin had driven Kate Hall, which had two heats to her credit. They took the mare away from him and placed her in charge of the police, and brought her to my stable where she remained under police protection all night. The judges asked me to drive her the next day. After I had jogged Kate Hall in the morning the judges, C. J. Hamlin, Chandler J. Wells and Myron P. Bush, visited me and looked over the mare. They asked about her condition and I told them the mare seemed to be all right and had taken her jog work nicely. They cautioned me against having any of her harness changed and told me to be sure to drive to win, adding that if I did not the heat would be called no heat and another driver put up. I told them I would drive according to instructions. I remember Mr. Hamlin's remark: "Bradburn will win if he can; I know he will." After it became noised about that I would drive Kate Hall I was offered fifteen hundred dollars to pull the mare and lose the race. Of course I refused, although I needed the money. Another party offered me 


\section{BREEDING THE TROTTER}

two thousand dollars to turn the same trick. I had no difficulty in winning, much to the satisfaction of Mr. Hamlin and the other judges and the owner, Mr. Hamilton. I was awarded one hundred dollars for driving.

\section{SUPERINTENDENT AT VILLAGE FARM.}

Village Farm, as Mr. Hamlin named his farm, because it was located within the village limits, grew rapidly and in $1880 \mathrm{Mr}$. Hamlin decided he needed a superintendent. He selected me.

From that time my duties were to manage the Village Farm in all its departments, and to be able each fall to turn a stable of prospects over to the Village Farm trainers.

\section{A BETting System.}

I might mention here an incident which occurred in I88I while I was racing Rockey for Mr. Hamlin, at which time Mr. Hamlin gave me some advice which I took to heart and profited by, as many others might well do.

Rockey looked very good for a certain race and I played almost all my money on him and lost. Mr. Hamlin heard of it. "Bradburn," he said, "make it a rule never to bet more than ten per cent of your money on a horse race. Then if you lose you have ninety per cent to commence on the next morning. They can't break you that way whether you are worth a hundred or a hundred thousand."

Billy Sargent had heard of my tough luck and felt sorry, so he told me he thought he had an 


\section{BREEDING THE TROTTER}

excellent chance to win with Josephus. I borrowed twenty dollars and bought two ten-dollar tickets which called for one hundred and ninety dollars and one hundred and seventy dollars respectively. Josephus won the first two heats, then Fanny Witherspoon the third and fourth. The race was postponed. I was not so confident as I might have been. My confidence was shaken when Crit Davis came to Mr. Hamlin and sold him Betty Mac, a half sister of Fanny Witherspoon and then in Kentucky, for five hundred dollars, so as to have more money to place on the Witherspoon mare. Betty Mac is the dam of $\mathrm{E} . \mathrm{S}$. E. (2.I 1/4) and Red Regent (2.I83/4), and the grandam of Ed. Easton (4) (2.093/4) and third dam of American Belle (3) (2.I 2 1/4). I went back to Josephus' stall and helped work on him that night. No horse received better attention. It was a matter of life and death with me. Josephus won the deciding heat. This put me on my feet and by the end of the meeting I had eight hundred dollars. After that I tried to follow Mr. Hamlin's advice about betting only ten per cent of one's money on a race, and never since then has John Bradburn been broke, although at times perhaps he has been "bent."

\section{VILLAGE FARM GRADUATES.}

After I became superintendent, the first trainer at Village Farm was Frank Baldwin, who was employed in 1882 and 1883 . Horace Brown was the next trainer, and his connection lasted from 


\section{BREEDING THE TROTTER}

I884 to I888, with W. J. Andrews, Malem Brown and Arthur Brown as assistants. Andrews was head trainer during $\mathrm{I} 889$ and $\mathrm{I} 890$, with great success. James Brigham was his assistant. In I89 I there was no regular trainer. The horses were prepared by George Moore and Billy Powell and turned over to Ed. Geers to be driven in races. In $1892 \mathrm{Mr}$. Geers was engaged as a regular trainer, and filled the position until I904, after which time Ben. F. White, Mr. Geers' assistant, took charge and was head trainer until the Village Farm was dispersed at the Fasig-Tipton Company's midwinter sale of February, I905.

While Mr. Geers was head trainer the following were engaged as his assistants at various times: Charlie Lyons, Charlie Niles, Harry Benedict and Ben. F. White.

The following have also trained at Village Farm : Alonzo McDonald, L. A. Dovel, Theodore Allen, Dave Clippenger, Lafe Schaeffer, John Graham, J. Scott Croy, W. L. Rhodes, George Bodimer, John Alward, Patsy Ready, Frank Vorhees, George Foster and James Humes.

Many of the prominent drivers of to-day, because of their former connection with the Village Farm, are known as "Village Farm Graduates."

A graduate of the Village Farm office force, well known to all horsemen, is E. J. Tranter, for many years cashier at Village Farm, afterwards senior partner of Tranter-Kenney Company, and now manager of the trotting department of FasigTipton Company. 


\section{BREEDING THE TROTTER}

IDEAL STOCK FARM.

Just previous to the Village Farm dispersal sale, Messrs. S. H. Knox and Daniel Good of Buffalo, N. Y., visited Village Farm and informed me that they had decided to embark in the breeding business, starting where Mr. Hamlin left off. They marked several horses which they liked, secured them at the sale and founded the Ideal Stock Farm, East Aurora, N. Y. They employed Ben. F. White as trainer and afterwards engaged me as superintendent. My candid opinion is, considering the quality of their horses, that they have started nearer right than any others who, to my knowledge, have ever entered the business. 


\section{Chapter Two}

\section{THE VILLAGE FARM THEORY OF BREEDING}

"World's Greatest Trotting Nursery."-Mr. Hamlin's First Mare.- Hamlin Patchen.-Mr. Hamlin's First Team. - Golddust.-Woful.- Mermaid and Dictator Maid.Weeding Out.- Nettie Murphy.-Minnequa Maid.- Purchasing a Premier. - More Purchases. - Estabella. - Almont Jr.- Mambrino King.- "The Handsomest Horse in the World." - Chimes.- Golden Gateway. - Rex Americus.Athanio.-Direct Hal. - The First Catalogue.-Mr. Hamlin's "Theory of Breeding." - The Brood-mare's Importance.Beauty and Speed.- Developed Sires. - A Challenge.- Selecting Brood-mares.- A Prediction.- "The Passing of Village Farm."

MHIS chapter will not be statistical nor entirely historical. I will attempt to show how certain things were accomplished at Village Farm so that the successful results may serve as an example to the younger generation of breeders.

WORLD'S GREATEST TROTTING NURSERY.

It must be remembered that Village Farm earned its sobriquet of "World's Greatest Trotting Nursery" by breeding more 2.I0 performers, among them many world's champions, than any other breeding establishment, and winning more money on the Grand Circuit than any other farm. Therefore, any breeder that "follows its lead" 


\section{BREEDING THE TROTTER}

and begins where it left off will not be left behind. Messrs. Knox and Good, in my opinion, have realized this better than any others, as will be seen by reading a portion of the announcement of their first catalogue, that of 1905 :

"In establishing Ideal Stock Farm it has been our aim to use, for foundation material, stallions and brood-mares bred on the most advanced lines and representing the results of the life work of the man who accomplished more in the way of breeding race-horses of extreme speed than any one breeder. When the Village Farm was dispersed, it was there we looked to secure the foundation for the Ideal Stock Farm, for the reason that Village Farm stood far in advance of all others in the production of horses possessing, in combination with speed, the beauty of conformation which enables them to win the highest honors in the show ring where beauty and good individuality are the qualities demanded."

Mr. Hamlin's desire to combine beauty and speed was born of an admiration, in the early days, of such stallions as Ethan Allen and George M. Patchen.

Mr. Hamlin used to say: "When you go into a ball-room you would much rather choose as a partner a beautiful woman that can dance well than a homely one that can dance equally well." He held similar views concerning beautiful horses with speed and horses with speed but which did not come up to his standard of beauty, 


\section{BREEDING THE TROTTER}

MR. HAMLIN'S FIRST MARE.

The first mare Mr. Hamlin ever owned was Little Belle, by Sherman Black Hawk, from the famous old-time race mare Belle of Saratoga (2.29), by Vermont Black Hawk. Little Belle was used as a road mare by her owner, then a country store-keeper in East Aurora, N. Y. Mr. Hamlin bred her to Addison, a son of Vermont Black Hawk, standing at Corning, N. Y., and the produce was Mag Addison. The latter was also used as a road mare and in I 862 was bred to George M. Patchen, then the champion trotting stallion and standing at one hundred dollars. The produce was Hamlin Patchen.

It was previous to breeding Hamlin Patchen, r857, to be exact, that Mr. Hamlin purchased the original sixty-six acres of Village Farm proper. This he added to from time to time.

Mr. Hamlin thought a great deal of Hamlin Patchen, his first stock horse, as will be seen from a portion of the announcement in the 1884 Village Farm catalogue.

\section{HAMLIN PATCHEN.}

"As I have so many of the descendants of Hamlin Patchen at Village Farm a few words about him may prove of interest to those who turn the pages of this catalogue. He was foaled in I862, and was sired by George M. Patchen, one of the finest-looking horses that ever struck the turf, and one of the fastest of his day. He made a record of $2.23 \frac{1}{2}$, and 2.30 performers came from 


\section{BREEDING THE TROTTER}

his loins. Hamlin Patchen is a strong, blockybuilt black, standing nearly $\mathrm{I} 5.3$ hands, and when three years old I had hopes that he would show the speed of his distinguished sire, but he was frightened by a dog, ran away to wagon and injured himself. Thus he was compelled to enter the stud without obtaining a turf record. His sons and daughters are hardy and pleasant drivers."

Hamlin Patchen's injury was a peculiar one. He was standing hitched on a barn floor when a dog ran through the stable. The horse reared and fell backwards, injuring his spine. On getting up he bolted out the door and while running away further injured himself.

\section{MR. HAMLIN'S FIRST TEAM.}

After securing Little Belle, one of Mr. Hamlin's next purchases was the team Tidy and LaBlonde, full sisters by Ethan Allen. They cost about six hundred dollars. Mr. Hamlin could drive them double close to 2.30. He could drive a double team better than any man I ever saw. These mares were sold to H. N. Smith, of the Fashion Stud Farm, Trenton, N. J., for four thousand dollars. Tidy was bred to Jay Gould and produced the dam of Boodle (2.12 1/2).

\section{GOLDDUST.}

One of Mr. Hamlin's next purchases was Golddust, by Dorsey's Golddust, dam by imported Glencoe. L. L. Dorsey had sent what he con- 


\section{BREEDING THE TROTTER}

sidered the best daughter of Golddust to Rysdyk's Hambletonian, hoping to get a stallion colt. The produce was the mare Bay Hambletonian. He bred the Golddust mare back and that fall shipped the mare and filly at side to Kentucky, via Buffalo. He unloaded at East Buffalo in order to give the mare and colt a rest, and invited his friend, Mr. Hamlin, to see them. Mr. Hamlin liked both so well he bought them for twelve hundred dollars, as I remember it. Unfortunately, the mare proved not with foal and was barren for several seasons. Finally, to the service of Hamlin Patchen, Golddust produced Black Golddust, dam of Justina (2.I3 to pole, 2.20 to harness) and Glendennis (2.171/4), and grandam of The Monk $\left(2.05 \frac{3}{4}\right)$, etc.

WOFUL.

In I873 Mr. Hamlin bought Woful by Minchen's Woful, from a Mr. Minchen of Orange County, N. Y. She is the third dam of Passing Belle $(2.081 / 4)$ and the fourth dam of Lord Derby $(2.05 \%$ ) (winner of seventy-four thousand eight hundred and twenty-five dollars on the Grand Circuit), Fantasy (2.06) and Shadow Chimes (2.05).

MERMAID AND DICTATOR MAID.

In I875 Mr. Hamlin purchased Mermaid and Dictator Maid, both by Dictator, paying for the former twenty-five hundred dollars and the latter fifteen hundred dollars. He liked the Dictator 


\section{BREEDING THE TROTTER}

strain and once offered twenty-one thousand dollars for Dictator when he was twenty-one years old. Mermaid founded a family and is the fourth dam of Dare Devil (2.09). Dictator Maid is the grandam of Globe (2.14 $\left.\frac{3}{4}\right)$.

\section{WEEDING OUT.}

On a rainy day in July, I88o, Mr. Hamlin visited the farm, and, calling me into the office, said :

"Bradburn, what do you think of my horses? I want your candid opinion. A horse is a horse, and a man is a man, be he good man or bad man."

My reply was, "Mr. Hamlin, what I would say to you about your horses would make you angry."

He said, "No, it will not. Spit it out."

Then I told him that were I a wealthy man breeding trotters, with the exception of four or five mares and Almont Jr., I wouldn't take his horses as a gift.

He studied over this awhile and then he asked me which ones I would take.

I replied that I liked Almont Jr. very much, on account of his style, finish and his having a great deal of natural speed for those days. My choice of the brood-mares was Bay Hambletonian, Miranda, Toy and Black Golddust. Among the fillies I liked Belle Hamlin, her sister, Belle Sloan, and Justina.

Naturally my selections out of fifty head were a matter of argument. Many of those I rejected were by Hamlin Patchen and Royal George. 


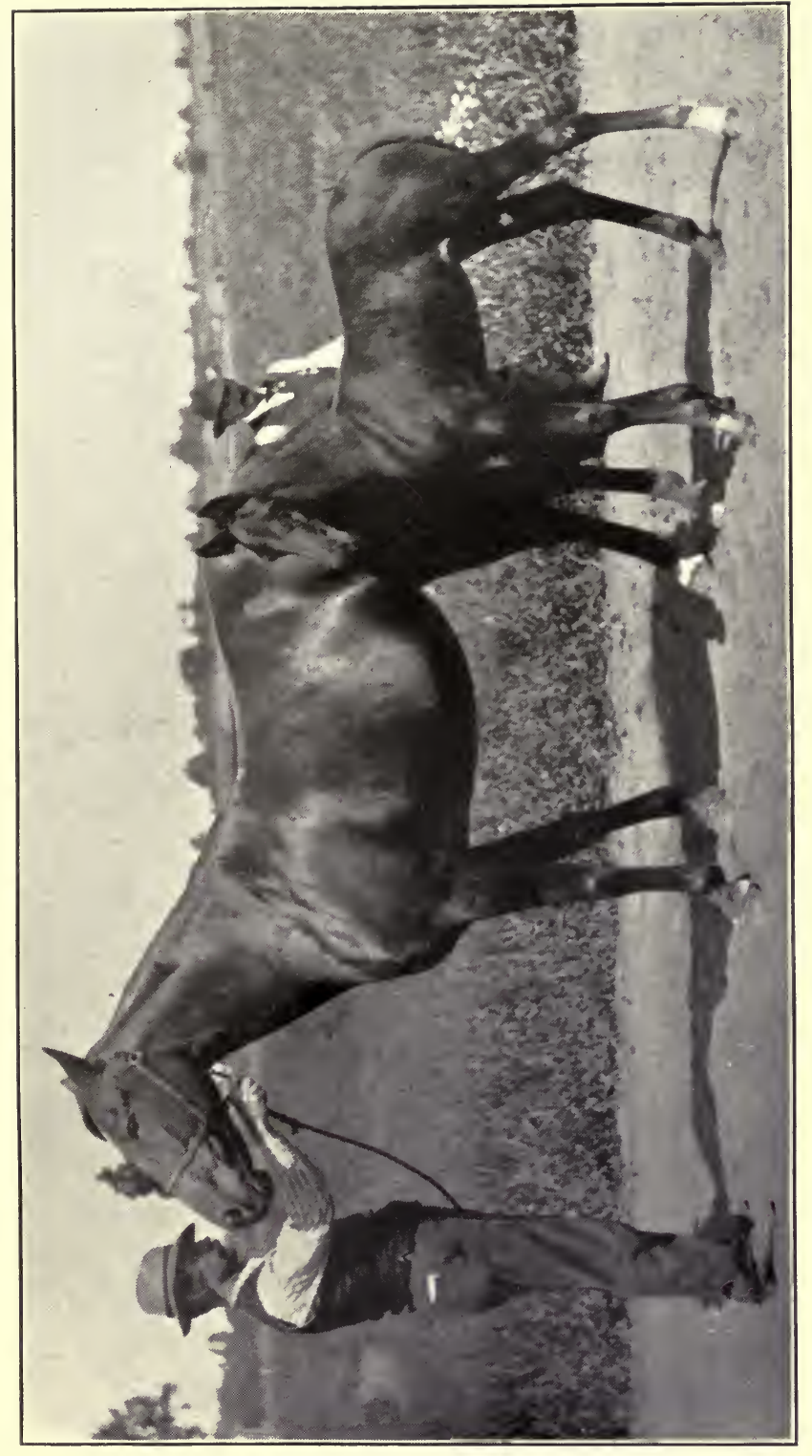

คิ

 

They were not good individuals. I told Mr. Hamlin that from what knowledge I had gained in breeding horses, cattle, sheep, pigs, chickens (especially game chickens), dogs, cats, etc., I was certain the families would not do.

It was now nearly train time so Mr. Hamlin asked me to prepare a list of the horses which I considered undesirable and have it ready for him the next time he visited the farm.

One of the first questions he asked on this next visit was, "Have you that list ready?"

"Yes, sir," I replied.

He looked it over and ordered me to sell all horses listed as soon as possible.

I suggested that he place a value on them.

" Ask a good, fair price," were his instructions, "but accept any offer you may get."

And thus the least desirable animals were weeded out.

NETTIE MURPHY.

In I88 I Mr. Hamlin purchased Nettie Murphy, for two hundred and fifty dollars, from Thomas J. Murphy of Buffalo. Bred to Mambrino King she produced Nettie King (2.201/4), dam of The Abbot (2.031/4), and The Beau Ideal (2.151/2).

MINNEQUA MAID.

The same year (I88I) Mr. Hamlin and myself went to look at Woods' Hambletonian, owned by Joseph Woods \& Bros., of Knoxville, Penn. This stallion was then coming before the public as a 


\section{BREEDING THE TROTTER}

sire, despite his limited opportunities because of his standing at an out-of-the-way place. Woods' Hambletonian was a roan horse and then twentythree years old. Mr. Hamlin offered six thousand dollars for him, but this was refused and seven thousand five hundred asked. While on this farm Mr. Hamlin paid two hundred and fifty dollars for Minnequa Maid, by Woods' Hambletonian, from a running-bred mare. Minnequa Maid, bred to Mambrino King, produced Nightingale (2.08), and bred to Chimes produced Milan Chimes (2.13 $3 / 4)$, whose racing career was ended by his untimely death, and Chimes Girl (2) (2.26). Bred to Heir-at-Law she produced Scape Goat (2.II $1 / 4)$.

PURCHASING A PREMIER.

After cleaning up the odds and ends, although Mr. Hamlin was a very busy man, it required very little argument to convince him that he must have some more good mares and another stallion, for at this time he had several Almont Jr. mares approaching breeding age.

In the spring of I882 $\mathrm{Mr}$. Hamlin sent me to Kentucky to look at stallions and brood-mares. I was seeking a son of George Wilkes, for I thought we needed some of the blood, although Mr. Hamlin did not like the Wilkes family. His objections to the Wilkeses were that they bred unevenly, toed out and were low headed. I looked at Alcantara, then a six-year-old; Alcyone, then a five-year-old, for which Mr. Hamlin afterwards 


\section{BREEDING THE TROTTER}

offered twenty thousand dollars; Onward, then a seven-year-old; and Red Wilkes, then an eightyear-old. I next visited Dr. Herr's farm and, for the first time, saw Mambrino Patchen and his ten-year-old son, Mambrino King, which horse had been playing second fiddle to his sire. I reported to Mr. Hamlin that I had never seen a horse till I saw Mambrino King. I came back home with a list of stallions and mares that could be purchased.

In the course of a month Mr. Hamlin went to Kentucky and purchased Mambrino King for seventeen thousand dollars; Gertie Smith, by Mambrino Patchen, for one thousand dollars; Play Girl, by Mambrino Patchen, for eight hundred dollars; Gerster, by Hero of Thorndale, for four hundred and fifty dollars, at auction. Mr. Hamlin's son, Mr. William Hamlin, purchased Goldfringe, by Mambrino King, for one thousand dollars. By this time Mr. Hamlin concluded ho had invested enough money in trotters so he tel. egraphed me to come to Lexington and attend to shipping his purchases home.

Soon after the purchase of Mambrino King, Mr. Hamlin's sons began to take a great deal of business off their father's shoulders and from that time on Mr. Hamlin made regular visits to the farm, when in Buffalo, on Wednesdays and Saturdays.

\section{MORE PURCHASES.}

In the spring of $188_{3} \mathrm{Mr}$. Hamlin again sent me to Kentucky to look for a young Wilkes stal- 


\section{BREEDING THE TROTTER}

lion to cross on the Mambrino King fillies when they came on.

Many of the "knockers" had called Mambrino King a "dude stallion" with nothing in the 2.30 list. As a matter of fact, on account of standing on the same farm with his sire, he had never had a good opportunity. I was instructed while on my Kentucky trip to look out also for some Mambrino King colts, which we could develop for the benefit of their sire.

After looking around Lexington I went to the farm of W. H. Wilson, Cynthiana, Ky., where I found Simmons, then four years old. I telegraphed Mr. Hamlin that I had found a stallion I believed would suit him and that I was on the track of some Mambrino King colts and fillies. We met at Lexington. Mr. Hamlin's first purchase was Queenie King, by Mambrino King, which he purchased of Mike Bowerman for seven hundred dollars. This was one of Bowerman's first highpriced sales. Queenie King afterwards produced The Queen (2.101/4) and King Chimes (2.103/4). The next horse bought was King Philip (2.26), by Mambrino King, which Mr. Hamlin and I purchased in partnership from Major P. P. Johnston, for twenty-five hundred dollars. At Dr. Herr's we had the choice of Silver King (2.261/2), aged two years, and Elyria, a yearling, for twentyfive hundred dollars. We chose the former because Elyria was smaller and a little double-gaited. We then went to Cynthiana and offered seventyfive hundred for Simmons, but as Mr. Wilson 


\section{BREEDING THE TROTTER}

would not sell for less than ten thousand dollars we returned without the horse.

ESTABELLA.

In the fall of I884 Mr. Hamlin went to Stony Ford Farm, Charles Backman, proprietor, and purchased Feroline, by Kentucky Prince, for five thousand dollars; Barbara, by Kentucky Prince, for two thousand dollars; and Marjorie, by Kentucky Prince, for twenty-five hundred dollars. Estabella, by Alcantara, owned by David Bonner, was on the same farm. She was then a little, low-down, squatty three-year-old filly, but we purchased her for one thousand dollars. Feroline produced the dam of Lord March (2.II 1/2). Estabella produced Heir-at-Law (2.053/4); Prince Regent (2.I61/2), for whom Charles Marvin once offered fifty thousand dollars; Princess Royal (2) (2.20), dam of The Earl (3) (2.I7), and Princess Chimes, the dam of Lady of the Manor (2.041/4), etc. A prominent breeder once offered twentyfive thousand dollars for either of two fillies by Chimes, from Estabella. Barbara produced Emily. (2.II).

Mr. Hamlin was a good judge of a horse and an excellent buyer. On the other hand he was a poor seller. Often after he had refused a good offer for a colt I have induced the would-be purchaser to return to the farm in Mr. Hamlin's absence and would effect a sale. I remember one occasion in particular when he refused an offer of twenty-five thousand dollars for four fillies and a 


\section{BREEDING THE TROTTER}

stud colt. He hated to sell his best, in fact, advised strongly against it.

Mr. Hamlin's first stallion was Hamlin Patchen, which he bred, as previously mentioned.

\section{ALMONT JR.}

He bought Almont Jr. (2.26) as a four-year-old in 1876 , paying Mr. William Payne of Scott County, Ky., twenty-five hundred dollars for him. He kept Almont Jr. until I89I, when he was leased two seasons to Mr. William C. Dickinson of the Connecticut River Stock Farm, Hatfield, Mass. Mr. Dickinson had bred a number of mares at Village Farm, and purchased Electmont, that has since sired Lady Sealskin (2.061/2) and others, for twenty-five hundred dollars.

In 1893 Almont Jr. was back at Village Farm. In 1900 he was leased to Stillman M. Thomas of Franklinville, N. Y., for four seasons. In I904 he was returned to Village Farm. He was then thirty-two years old but vigorous and was allowed to cover a coach mare, which he got with foal. As his teeth were decaying rapidly the horse was chloroformed.

\section{MAMBRINO KING.}

The purchase of Mambrino King was spoken of in connection with the brood-mare purchases.

Mr. Hamlin thought so much of Mambrino King that he always "spread" on him in his catalogues. The following is what he said of the horse in his first catalogue, that of 1884 : 


\section{BREEDING THE TROTTER}

" THE HANDSOMEST HORSE IN THE WORLD."

"Mambrino King stands I 5.3 hands, and he is universally conceded to be what the French Commissioners pronounced him, "The handsomest horse in the world.' He combines strength, intelligence, courage, faultless action and good breeding with symmetry and style. His second dam was the dam of Fisk's Mambrino Chief, a horse that sold for twelve thousand dollars. His legs are stoutly corded and free from blemish, and his feet are entirely sound. He has no imperfections to transmit and, judging him by his stud fruits, he has the power to stamp out defects in the dam.

" $\mathrm{He}$ has never been put in trotting condition, but has often been driven by Dr. Herr and his colored groom quarters in thirty-four and thirtyfive seconds and thirty-five and a fraction, in the presence of David Bonner and hundreds of others. In the fall of I88 I he showed in an exhibition trot at the Lexington Fair, when he was speeded, a half-mile in I.I 4 ; jogged to the half-mile pole and repeated in just exactly the same time, without making a break or the least urging, and this after the regular season in the stud. He wears light shoes and no toe-weights. Dr. Herr writes me that the colts left in Kentucky by him are coming to the front as trotters, and he predicts that in three years from now Mambrino King will stand at the head of all trotting stallions. He has a rich speed inheritance, and this he can hardly fail to perpetuate. I paid a large price for him, and during the short period he has been located at 


\section{BREEDING THE TROTTER}

Village Farm not less than sixteen thousand people have called to see and admire him.* I believe in breeding a class of horses which possess beauty and style as well as speed, and am satisfied that I will accomplish my purpose by using Mambrino King in the stud. I reproduce in this connection a description of the horse, written by the well-known S. T. H., of Cincinnati :

" "His rich, satin-like coat glistening in the sunlight, more handsome in his exquisite proportions and lofty in his splendid carriage than the proudest Nedjed Arabian of the desert. Indeed, as he stood before us, his eyes flashing and his gazelle ears pointing forward, and his arching neck revealing the delicate network of swelling veins, and his symmetrical barrel revealing every contour of equine beauty, and his full, flowing tail, gracefully floating like a gossamer banner, we thought that if he could be instantly transformed into marble he would remain forever the sculptor's model of an ideal horse.'

"I also call attention to the following extract from the official report of Baron Favorot de Kerbeck, French Colonel of Dragoons, who was deputed by his government to make an extensive tour of inspection of the horses of America:

" Mambrino King is the most splendid specimen we have had an opportunity of admiring. Imagine an Alfred de Dreux, a burnt chestnut, whole colored, standing 15.3 hands, with an ex-

\footnotetext{
*I recall one day when Mambrino King was taken out of his stall to be shown to visiturs one hundred and seventy times. John Bradburn.
} 


\section{BREEDING THE TROTTER}

pressive head; large, intelligent and spirited eyes; well-opened lower jaws, well-set ears; the neck and shoulders splendidly shaped, long and gracefully rounded off; the shoulders strong and thrown back well; the withers well in place and top muscular, the ribs round and loin superb, the crupper long and broad; limbs exceedingly fine, the joints powerful; the tail carried majestically and all the movements high and spirited-imagine all this and you have an idea of this stallion. $\mathrm{He}$ is as open, if we look at him in front, as he is in his hind quarters - the whole animal being an embodiment of purity of lines, elegance and elasticity. He is, in fact, perfection.'

Later, Mr. Hamlin added this paragraph to his description of the horse :

"It should be borne in mind that until he was ten years of age Mambrino King was owned by Dr. Herr, and being so overshadowed in reputation as a stock horse by his famous sire, Mambrino Patchen, he had few or no opportunities of serving mares of the best breeding. The natural speed and great beauty of the fillies which I have seen that were sired by him when he was in Kentucky, and the same qualities in those which he has sired since he came to Village Farm, together with the fact that Mambrino King is far more beautiful and more richly bred than Mambrino Patchen, warrant me in making the prediction that his daughters will be superior as brood-mares to those of his sire, which have proven themselves the most valuable of any in the country. 


\section{BREEDING THE TROTTER}

In this opinion I am fully sustained by the judgment of Dr. Herr."

Without special preparation Horace Brown once drove Mambrino King a public exhibition half-mile, at Buffalo, in I.I2, with the horse in stud condition.

Mambrino King was still vigorous at twentyseven years but his teeth were decaying and he had a painful injury on the knee, due to the kick of a mare, and he was chloroformed.

\section{CHIMES.}

When the Mambrino King fillies came on it was necessary to select a stallion to cross on them. Usually Mr. Hamlin would buy for Village Farm anything I advised. Effecting the purchase of Chimes was the hardest proposition I ever ran up against. I had first seen Chimes at Rochester, N. Y., as a yearling in the fall of 1885 . I was working out a mare that could step around 2.32 . Charlie Marvin was out behind Chimes and asked me how fast I was going. I replied, "Around 2.40, with the last half in twelve." "I'11 work with you," he said. Horace Brown was out behind a mare and the three of us worked together, giving the colt the pole. Chimes kept the mares busy to the half, while Marvin was buggy riding. At the head of the stretch the two mares were on their toes, while Marvin commenced moving away. Chimes was soon so far in the lead that I was ashamed to finish the mile and, pulling 


\section{BREEDING THE TROTTER}

my mare up, I turned around and went back to the stable.

I talked Chimes all winter. $\mathrm{He}$ was a rapidgoing colt and would, I thought, mate well with the Mambrino Kings, which did not have enough knee action and were long striders. Mr. Hamlin saw Chimes that fall at the St. Louis Fair but was not greatly impressed, because the colt went low headed and did not carry his tail as Mr. Hamlin liked to see a horse do. In I886, while at Saginaw, Mich., Mr. Hamlin promised to make an offer for Chimes. He asked Marvin what the colt could be bought for. Marvin replied, " $\mathrm{He}$ is the best colt we ever raised and I do not care to price him. However, I will telegraph any fair offer you may make to Governor Stanford." Stanford was at that time in the Senate at Washington. Mr. Hamlin offered ten thousand dollars for the colt. Marvin said he did not like to telegraph so low an offer. Mr. Hamlin then offered twelve thousand dollars and Marvin telegraphed his employer to that effect. Governor Stanford's answer was that if the colt was going to a good home and the sale was for cash, to sell. That was how Chimes came into the possession of $\mathrm{Mr}$. Hamlin.

We worked Chimes a mile in 2.25 as a two-yearold. In the spring of $\mathrm{I} 887$, as a three-year-old, we bred him to sixteen mares and raced him that summer. He won nine thousand dollars and took a record of $2.303 / 4$, which was no measure of his speed. Marvin, in his book, tells of driving 


\section{BREEDING THE TROTTER}

Chimes a quarter in thirty-five seconds at fifteen months. Chimes was very successful in the stud, financially and otherwise. One year he made twenty-one thousand dollars for Village Farm, covering forty-two outside mares at five hundred dollars.

\section{GOLDEN GATEWAY.}

Golden Gateway, by Guy Wilkes (2.151/4), was purchased at auction in $\mathrm{I} 889$, when he was ten months old, for fifty-one hundred dollars. $\mathrm{He}$ was believed to be the first colt with three producing dams.

\section{REX AMERICUS.}

Rex Americus (2.I I 1/4) was purchased, as a twoyear-old, from J. H. Thayer, for fifteen thousand dollars. He made a season as a three-year-old, producing Battleton (2.093/4) and American Belle (2.1 $\left.2 \frac{1}{4}\right)$ from these services.

\section{ATHANIO.}

In I895 Mr. Hamlin and Mr. Geers purchased Athanio (2) (2.191/2), from George L. Warton, Fresno, Cal., for twelve hundred dollars. After taking a record of 2.I0 he was sold at auction for three thousand seven hundred and fifty dollars and went to Austria.

\section{DIRECT HAL.}

The last stallion Mr. Hamlin purchased, and the only pacing stallion, was Direct Hal, owned 


\section{BREEDING THE TROTTER}

by Mr. Ed. Geers. I saw Direct Hal first as a two-year-old and liked him. At that time we had about gone the limit on the Mambrino KingChimes cross and needed an outcross. As some of our mares produced fast pacers I thought Direct $\mathrm{Hal}$ would make a good cross and advised Mr. Hamlin to breed some mares to him. To this suggestion he replied, "If I want the use of a stallion I can afford to own him. What do you suppose people would say if I bred to an outside stallion? I don't want to dig my own grave. Let some one else do that." It was some time before Mr. Hamlin could induce Mr. Geers to sell, but the horse finally changed hands for ten thousand dollars. At that time his fastest mile had been in 2.17 $1 / 4$ with a half in 1.06 . We bred him as a four-year-old and five-year-old, and in the latter year he worked a mile in 2.061/4. As a sixyear-old he was raced. He was unbeaten down the Grand Circuit and took a record of $2.04 \frac{1}{4}$, winning twenty-six thousand five hundred dollars. At one time Direct $\mathrm{Hal}$ could have been sold for forty thousand dollars.

\section{THE FIRST CATALOGUE.}

The Village Farm catalogues record many of Mr. Hamlin's views on the breeding problem.

The first catalogue of Village Farm was issued in I884. It was my first experience as a catalogue compiler and I never worked so hard on anything in my life. At that time the facilities for compiling catalogues were not what they now are and 


\section{BREEDING THE TROTTER}

the tracing of pedigrees and establishing of dates was a tedious undertaking.

In the announcement of the I884 catalogue Mr. Hamlin briefly outlined his " theory of breeding," as he called it, in these words :

\section{MR. HAMLIN'S THEORY OF BREEDING.}

"My great aim in breeding is to combine speed with size, soundness, style and elegance of form. In the pursuit of this object I have weeded from the list the mares which have not produced foals up to the standard, and the stallions have been selected with the greatest care."

Speaking of weeding out I might mention that a great deal of it was done at Village Farm. If a stallion colt was not up to the standard he was gelded. If a colt came crooked we knew it was the mare's fault. The colt was killed and the mare sold.

Speaking of these brood-mares Mr. Hamlin, in his I884 catalogue, published the following opinion :

THE BROOD-MARE'S IMPORTANCE.

"The brood-mares cover every branch of the explored field. Every line of demonstrated worth has been given a place in the collection. As I wish to stamp out, instead of to perpetuate, infirmities, no mare has been purchased or retained, regardless of fashionable breeding, which has a blemish of a constitutional character. I believe that the brood-mare is an important factor in the 


\section{BREEDING THE TROTTER}

problem of reproduction, and so I have given as much thought to her selection as to that of the stallion.

"I do not see how I can fail, by grafting the best qualities of one family upon the best qualities of another family, to produce a superior breed of horses. I believe in giving to the foal the capacity to trot young, but I am opposed to the abuse of this capacity. I shall not, as a rule, impose a strain upon the colts which the joints and ligaments are in no condition to sustain, therefore few reports of fast trials of yearlings and twoyear-olds will go out from Village Farm. The man who waits upon a colt until it matures will have the satisfaction of owning an animal able to stand the wear and tear of the road and track."

\section{BEAUTY AND SPEED.}

Mr. Hamlin was continually preaching, through his catalogues and the public prints, his doctrine of combining beauty and speed. In his 1885 catalogue he says :

"The get of a very large percentage of the plain trotting stallions now in use in this country have no speed, and, being without beauty or other attractive qualities, can be marketed only for street railroad and other ordinary purposes at prices that do not pay the breeder one-half what it costs to raise them. This is the cause of a great number of breeders becoming disgusted with the business." 


\section{BREEDING THE TROTTER}

In the I89I catalogue he had more to say on the same subject :

"I wish briefly to direct attention to a few points which, in my judgment, are of the greatest moment to the breeding world. The crowning ambition of every breeder is to produce a perfect horse, but it is evident to careful observers that much must be accomplished before the hope is realized. Progress is not dead, but some breeders are more progressive than others. The cardinal points in the make-up of a perfect horse are beauty, size, strength, endurance, intelligence, speed and balance. The absence of any of these points would cause the animal to fall short of the standard of perfection."

\section{DEVELOPED SIRES.}

About this time Mr. Hamlin became convinced that hard-racing campaigns sap the vitality of a stallion and make him undesirable for a stock horse. These views, when they appeared in the Turf, Field and Farm, were widely criticised. He continued the controversy in his I888 catalogue in which he says:

"All breeders are more or less rivals, each being anxious to excel the other. This being the case, I feel privileged to say a few words about the claims put forward by the owners of other stallions, especially those stallions with fast records. I combat the theory that stallions with low records are of the highest value for breeding purposes. I contend that the fastest and gamest performers 


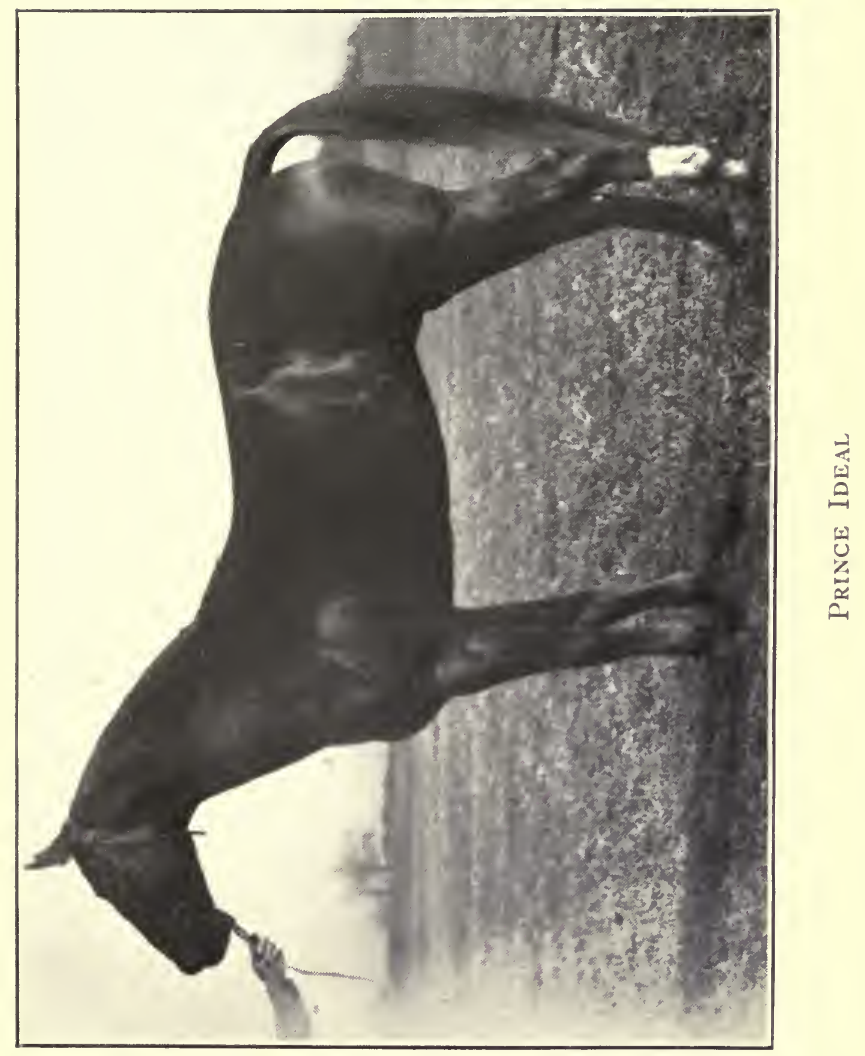





\section{BREEDING THE TROTTER}

are not likely to come from them. It is beyond dispute that a horse which trots race after race passes through a vitality-sapping ordeal. The stallion that is trained, season after season, for the purpose of forcing him down to the lowest record made, goes through a continual strain which necessarily takes from him something of the vigor so important to the highest results in the stud. The hard work of the track causes a waste of the vital force, so much needed in perfect stock-getting. I believe that the stallion which is overworked for the sake of a record has his ability for reproducing speed weakened instead of increased, and to show my sincerity on this point, to prove my faith by my words, I offer the following challenge :

\section{A CHALLENGE.}

"I will trot this coming season heats, best two in three, under the rules of the National Trotting Association, over any good mile track, as convenient to reach by both parties as possible, four of the get of Mambrino King (an undeveloped stallion), foaled in 1885 , bred, raised, developed and owned at Village Farm, against any four of the same age, bred, raised, developed and owned by the owner of any stallion having a record of $\mathbf{2 . 2 2}$ or better, the said four to have been sired after the stallion had obtained his fastest record. I will make each of the four races for from one to one thousand dollars a side, and I would prefer that the challenge be accepted by the owner 
of Phallas (2.I3 $3 \frac{4}{4}$ ), or the owner of Jerome Eddy (2.I61/2). Both of the stallions named are fast, but up to the present time I have been unable to discover that either has sired a trotter. I am willing, however, to go on a voyage of discovery, and my proposition cannot be deemed one-sided, for the reason that both stallions have a large number of colts of the proper age from which their owners, who employ first-class trainers, can make selections. If the theory is sound that a horse which has trotted a wonderfully fast mile should necessarily get very fast stock, the advantage should be with Phallas and Jerome Eddy, because they have the fastest records and have been serving mares for several years past at high prices. For the good of the trotting community, as well as for those breeding with the hope of getting a trotter, I think it time that the bubble, so full of deceptive ideas, should be pricked."

How this challenge was received is best told by Mr. Hamlin himself in his I 889 catalogue :

"This direct and business-like proposition stirred up a series of cyclones throughout the country, and although many counter-propositions were made by the owners of developed stallions, not one of these had the courage to accept my challenge. The four three-year-olds by Mambrino King, upon which I depended, did not disappoint me. Every one showed the ability to trot in from 2.25 to 2.35 . One trotted a trial in 2.26 , and the other two trotted in 2.3 I. Mambrino King is all I have claimed him to be." 


\section{BREEDING THE TROTTER}

SELECTING BROOD-MARES.

Mr. Hamlin was not only a non-believer in tincup records, but did not consider it necessary to race a mare in order to make a successful broodmare. He thought nothing of stopping us working our best fillies and ordering them to be placed in the harem. For that reason most of Village Farm's fastest performers were stallions or geldings.

On many an occasion have the Village Farm trainers been actually sickened when prospective 2. Io trotters were taken from their strings to be placed in the brood-mare ranks.

\section{A PREDICTION.}

Mr. Hamlin took great pleasure in making predictions in his catalogues, almost all of which were fulfilled. The most important one appeared in his catalogue for $\mathrm{r} 89 \mathrm{I}$ :

"While it is dangerous to make predictions, and while I realize that the whole world is in competition, I wish it recorded that there are now on Village Farm a number of youngsters that will score lower marks in contested races than have heretofore been made by any trotter, living or dead.'

Several world's champions afterwards appeared to fulfil this prediction.

" THE PASSING OF VILLAGE FARM."

Before leaving Village Farm to take up the practical side of this book, I wish to call atten- 


\section{BREEDING THE TROTTER}

tion to what I consider the best eulogy written on this famous establishment. It was penned by Rev. Andrew M. Shea, of Ames, Ia., one of our patrons, and was published, I think, in the Spirit of the West, of Des Moines, Ia., but is deserving of a wider circulation. I am sorry there is not space here to print the entire article, excerpts from which follow :

"Life is full of pathos. Change and decay characterize our journey between birth and judgment. In obedience to this principle everything advances, either in an increasing or a decreasing series. The solid granite gradually crumbles into dust; the tall oak of the forest is first a tender shoot, then a green sapling, until, ultimately, it is succeeded by decay. So with the institutions of man-they are first seen in the tenderness of infancy, then in the beauty of youth, then in the strength of maturity, till age steals on apace, impairing their beauty, wasting their freshness and destroying their strength, till, bowing under the weight of infirmities or ceasing to be among men, their day has become night and their mission history. The experiences and enterprises of Leland Stanford, Robert Bonner and J. Malcolm Forbes constitute personal illustrations of this transitory life. And now comes the announcement of the absolute dispersal of Village Farm, and though Mr. Cicero J. Hamlin, its distinguished founder, at least as great, if not indeed the greatest Roman of them all, still lingers this side of the portals of the grave, it is appar- 


\section{BREEDING THE TROTTER}

ent to his friends and to none more so than the great horseman himself that he too must soon join his colleagues in the invisible land, and herein, perhaps, more than anything else, lies the secret of 'The Passing of Village Farm.'*

"And what a farm it has been! What history it has made! How vastly different the records of the turf would read had Village Farm never had an existence! The list of men who have mixed brains with the founding of a stock farm and have carried the enterprise to successful consummation, at least in the degree, as has Mr. Hamlin, is not large. Few men are entitled to start in his class. His judgment in selecting and handling Mambrino King and Chimes has been vindicated by their achievements. . . .

"In the spring of 1903 the writer bade adieu to the dear ones of his Western home, climbed into a box car with our three-year-old filly, whose blood lines read like a poem and whose ancestors have distinguished themselves in the stud and on the track, and sped away to Village Farm. After the varied experiences incident to travel by freight we reached East Aurora, N. Y. We went to the depot 'phone and called up Village Farm, from which came the courteous reply, "We will send for you and your mare immediately.' In due time came a man on horseback for the idol of our heart and the foundation of our dreamsdreams of a colt, a sale at a long price, and a trip to the Holy Land. Just behind him rode another

*Mr. Hamlin died February 20,1905, scarcely three weeks after the Village Farm dispersal sale. 


\section{BREEDING THE TROTTER}

behind an attractive-looking pacer hitched to a top buggy. We were invited to a seat behind the pacer and in response to our inquiry, 'What's this you are driving?' the driver smiled and said, 'You are now riding behind Hal Pointer.' Confess, yes; we can but be true. Our first impulse was to tip our hat and then get out and walk. Shades of the great ones! Had we not read and re-read the Hal Pointer-Direct duels? Had not our heart beat fast as the dailies told of his demonstrating to the world that a horse could pace in less than 2.05? Had we not said, 'I wish I could see him'? And behold, we were actually riding behind him. And notwithstanding Mr. Bradburn's most cordial welcome and the fact that we had had nothing warm to eat for four days, we actually stood on the office porch until the old hero had entered the barn. .. . Like the Queen of Sheba, who had heard the glories of Solomon, we, too, had heard of the greatness of Village Farm, but we confess in the language of the ancient queen, ' The half had not been told.' . . . However, as we are writing about the passing of things, we pause to note that it was here The Abbot struggled to get command of himself and, after succeeding, flew to the top and carried the world's record-a coveted crown-to the camp of his owner. But where is he? Gone! Passed forever! From this spot, a few days ago, we looked away to the hillside where rest the bones of old Hal Pointer. How are the mighty fallen, and now the entire plant is to become a thing of the past." 


\section{Chapter Three}

\section{FOUNDING A STOCK FARM}

Location.-Soil.-Water.-Size of Farm.-Acres of Land per Head. - The Track. - Rules for Laying out Track. - The Cinder Track. - Paddocks. - Fencing. - Stables. Main Barn.- Water in Paddock. - Brood-mare Shed.- The Farm Superintendent.

T this point I will take it for granted that
I have satisfactorily explained to the reader
who I am, have told as much of my history as he will be interested in knowing, have shown how my knowledge of horses was gained, and have described how that experience was applied to the management of Village Farm.

With this in mind, I will presume to write several chapters of advice on the breeding and development of trotters, with advice on the management of stock farms. I propose to begin at the very beginning and will devote this chapter to the founding of a stock farm.

\section{LOCATION.}

We will suppose that the reader contemplates starting in the breeding business and has come to that point where he must decide on the location of his stock farm, be it large or small.

Those who are expecting a long-winded argument on the climatic theory will be disappointed. 


\section{BREEDING THE TROTTER}

In my opinion the main thing to be considered is to locate the farm within easy access of its owner's place of business. If the owner lives in a large city his farm should be at some point not farther away than thirty or forty minutes' ride by rail. The farm should be so located that the owner can visit it often and at all seasons without tedious journeys, otherwise he is liable to lose interest and quit the business.

The nearer the farm is to the railroad station the better, and the less expense the owner is put to in hauling supplies. This is an important factor. For every mile the cost of hauling increases expenses hundreds of dollars, according to the size of the plant, and this soon runs into thousands.

The farm that is within ten or fifteen minutes' walk of the depot is admirably located. The owner, his friends, or visitors, can reach such a farm without a tiresome drive. Too many of our large stock farms are almost inaccessible.

\section{SOIL.}

In locating a stock farm at any particular point, if there is any choice of soil I would prefer it to be sandy or gravelly. The muddy season will be shorter and the grass will come earlier and stay later. Rolling, but not hilly, land has my preference.

WATER.

If possible there should be spring water on the 


\section{BREEDING THE TROTTER}

farm. It is the best water for man or beast to drink, and for both is the most pleasant and healthful.

\section{SIZE OF FARM.}

Now as to the size of the farm, that will depend on the amount of stock. If I were a millionaire I would never want over forty brood-mares and would prefer twenty. Twenty brood-mares will raise enough colts to keep a trainer busy. If you start on twenty mares, by the time your oldest foals are four years old you should have sixtyeight or seventy colts to keep your trainers occupied.

After deciding on the number of brood-mares you wish to start with it will become necessary to determine how many acres of land will be required to support each mare.

\section{ACRES OF LAND PER HEAD.}

In New York State your mare will live on grass for about six months. Two acres of pasturage should keep her, and colt by side, for the season.

During the winter months she will eat about fifteen pounds of hay per day, for six months, or about twenty-seven hundred pounds in all. In New York State one acre of land will raise this much hay or more each season.

If you wish to raise your own oats, you will have to allow the mare more ground. During the six winter months she will be fed about six quarts of oats a day (in addition to bran, wheat, etc., as set 


\section{BREEDING THE TROTTER}

forth in chapter five), or about thirty-five bushels for the season. This will require, in New York State, seven-tenths of an acre of land.

The straw from this land will provide enough bedding for your mare during the winter if your men are not wasteful.

Sooner or later the colts will come on and you will need more land. We will suppose that you keep all the colts until they are two years old. This will give you the pleasure of breaking and driving them and developing their speed if they have any. In the long run you will make a larger net profit selling your colts as two-year-olds than at any other age.

Now, to determine how much land will be needed to support the colts. The weanlings should have eight pounds of hay per day during the winter months or seven hundred pounds for the season. One quarter of an acre of land will keep the weanling in hay every season. When the yearlings come on they will eat almost as much hay as aged horses. The weanling will eat seven quarts of oats per day or forty bushels during the winter. Four-fifths of an acre of ground will raise enough oats for the weanling. The yearlings will eat the same amount during the breaking season and following winter. One and three-fifths acres will raise the oats needed for this purpose. After your oldest foals are yearlings, in order to be prepared to support your mare, her weanling and her yearling up to the spring of its two-year-old form, you must have 


\section{BREEDING THE TROTTER}

seven and one-half acres of land for each mare you started with, figured as follows :

Two acres in pasturage for mare; one acre in hay for mare; seven-tenths acre in oats for the mare; one-fourth acre in hay for the weanling; one acre in hay for the yearling; four-fifths acres of oats for the weanling; one and three-fifths acres of oats for the yearling.

Of course if you keep your colts after the spring of their two-year-old form you will need more land, but the above figures give you a basis to work on.

\section{THE TRACK.}

After the farm is purchased the plot should be selected on which to lay out either a mile or a halfmile track. If possible this should be located somewhere within sight of the public highway. It is a good advertisement for the farm, besides giving it a "ready-for-business" appearance. With the track so located visitors will not have to go to a distant part of the farm to see the horses work.

I prefer that the track be laid out on low ground if convenient. By doing this you get away from the high winds, the soil : usually soft and spongy, and the track does not get hard.

\section{RULES FOR LAYING OUT TRACKS.}

For reference, the rules for laying out tracks are here inserted :

To lay out a half-mile track, lay off two straight sides, six hundred feet each (parallel) and four 


\section{BREEDING THE TROTTER}

hundred and fifty-two feet four and three-eighths inches apart, connected at each end with a perfect semi-circle (radius two hundred and twentysix feet, two and three-sixteenths inches). Place the fence exactly upon a line so formed (which is the inside of the track), and the track will measure exactly half a mile three feet from the inside fence, to be placed according to the width of the track desired. Thirteen acres will be required for a half-mile track thirty feet wide, fifteen acres for a half-mile track sixty feet wide.

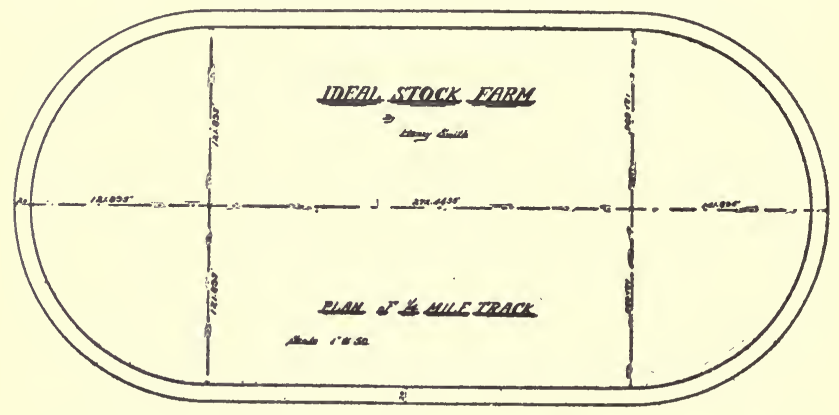

If not convenient to obtain an engineer to run the curve, it can be done as follows: Place a stake midway between the parallel straight lines at each end; take a wire with the loop at the end, loose enough to turn upon the stake, and measure upon this wire two hundred and thirty-six feet two and three sixteenthis inches (the radius of the curve), which from the centre stake will exactly reach the ends of the straight lines; then describe a semi-circle, beginning at the end of one side, 
putting down a stake every twelve feet, if this is the length of the fence panels desired.

To lay out a full mile track, select a level field of forty-two acres; draw through the center of it a straight line of four hundred and forty yards (a quarter of a mile). On each side of this line, and an exact distance of one hundred and forty yards two inches from it, draw parallel lines of equal length, so that the space between the two outer lines will be two hundred and eighty yards, four inches.

This being done, a stake should be driven at each end of the centre line; a cord should be fastened thereto. Extend the cord at right angles for one hundred and forty yards two inches, until it touches the end of the outer line, and then describe with the extreme end of the cord an outer curve or semi-circle between the ends of the two outer lines. There will be a continuous outer line, being exactly a mile (one thousand seven hundred and sixty yards) in length, and requiring an enclosure of forty-six acres of ground. From this outer line or track, set the fence of the course three feet in on the straight sides and curves. In this way an exact mile (as near as may be) is preserved for the actual foot track of all the horses. The first distance post is sixty yards from the judges' stand, the second is two hundred and forty yards, and the stand is sixty yards before entering the turn. The track should be graded around the turn like the track of a railroad or circus, the outer portion highest, so that a horse can extend himself at full speed. 


\section{BREEDING THE TROTTER}

THE CINDER TRACK.

A cinder track should be built inside of the main track, about three-eighths of a mile in circumference, with turns well thrown up. The track should be from fifteen to twenty feet wide and fenced on both sides. This makes a miniature track for leading and breaking colts and jogging in muddy weather when you cannot get onto your main track.

\section{PADDOCKS.}

In dividing your farm and in fencing remember to have plenty of paddocks from one to five acresdifferent sizes for different purposes.

Most farms have a large pasture-field for their brood-mares. I prefer dividing them into lots or pasture-fields of not over ten acres. If there is no shade in the pastures then trees should be set out in order to afford the mares protection from sun, storms and flies. In some of the broodmare pastures you will want small feeding paddocks for the colts, as mentioned in chapter five.

To lay out the farm in the most convenient manner, a road should be built through the center so that the owner, his family, his friends or visitors, can drive about the farm and see all the horses without wasting a lot of time driving through the fields.

FENCING.

As to fencing, never allow any barbed wire on the place. A board fence, five feet high, is the 


\section{BREEDING THE TROTTER}

best. I prefer sixteen-foot boards with posts set eight feet apart and three and a half feet in the ground. The fence should be capped with a sixinch board. The posts should be of cedar, chestnut or second-growth oak, which I fancy in the order named. A fence properly built will last twenty-five years. There should be good, strong gates connecting the lots.

\section{STABLES.}

When the time comes to build stables you will probably first build your main barn. Later, if you have a large number of colts to train, it will be necessary to build a training barn near the track. When it comes time to build this barn locate it where visitors are least likely to visit it and bother your men.

\section{MAIN BARN.}

The main barn on the largest farms should contain from thirty to thirty-six stalls. Sixteen stalls are enough for one training barn to contain.

In the main barn there should be a hallway, twenty feet wide, of yellow clay that will pack solid and clean. This is the most sanitary flooring. The barn should be light, airy and well ventilated. If possible, it should be lighted by electricity, with gas as second choice. If this cannot be done lanterns will have to be used. Establish a rule on the farm that no lanterns shall be carried about unless absolutely necessary. Enforce this rule as a precaution against fire. 


\section{BREEDING THE TROTTER}

Ailow no smoking or lighting of matches in the barn. The evening feeding should be done before dark so that it will not be necessary to use lanterns.

The stalls should be of different sizes, for instance, twelve by fourteen, twelve by twelve, ten by twelve, while a few eight by twelve stalls may be built for weanlings.

Everything should be arranged as conveniently as possible. The grain and bran bins should be so placed overhead that the feed will not have to be carried long distances. Water hydrants should be so located that water will not have to be carried any further away than three stalls. This makes it easier for the men, is time saved, that means money and affords increased fire protection.

The main barn should contain an office or waiting room for the owner and visitors, and adjoining working office where the records may be kept.

I present herewith plans of what I consider an ideal main barn for a stock farm, except that I would prefer it from four to six feet higher, in order to have more room for hay.

As to building material, that depends upon how much architectural beauty is desired. I prefer a wooden barn to one of stone or brick because it is drier.

\section{WATER IN PADDOCKS.}

I have previously mentioned the importance of good water. There should be running water, 


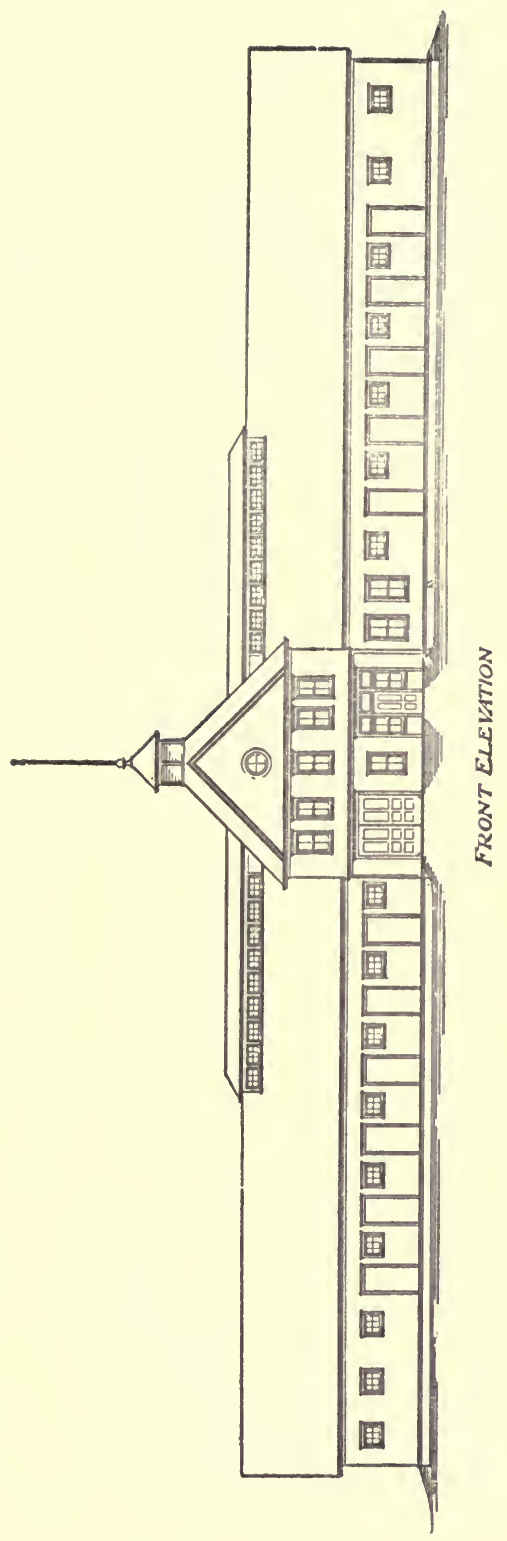




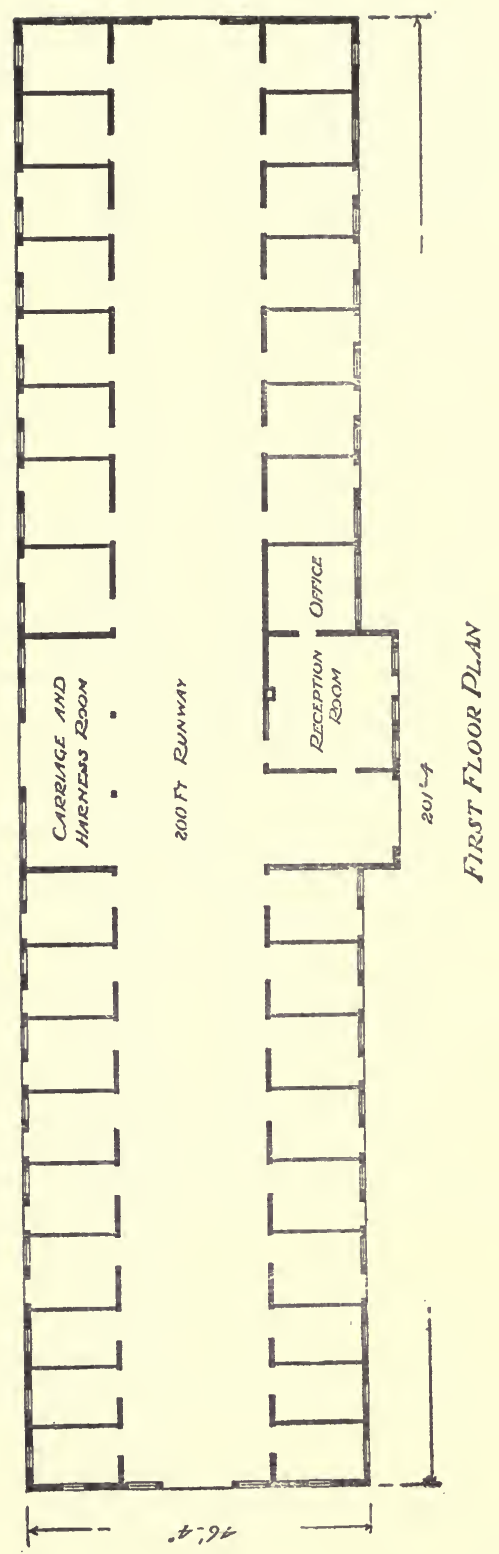




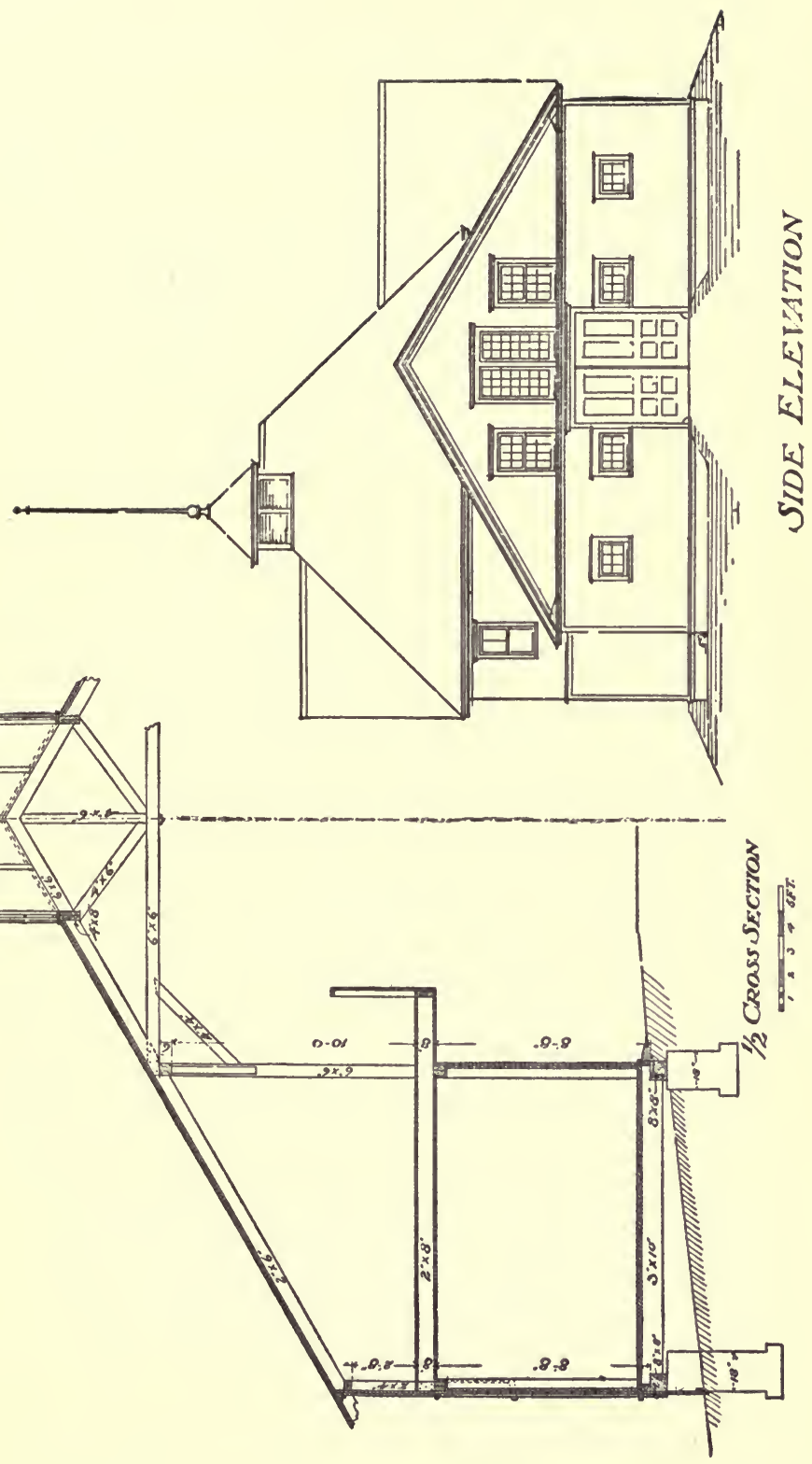




\section{BREEDING THE TROTTER}

spring water if possible, in all lots and paddocks.

The troughs should be eight to twelve feet long and about sixteen inches deep. A large trough is better than a small one, because it does not become heated so quickly in summer. Pine wood makes the best troughs. The tops should be covered with tin, zinc, or galvanized iron, so that the horses will not eat the wood. The troughs should be well painted. They will look neater and last longer.

\section{BROOD-MARE SHEDS.}

We now come to the brood-mare barn. No matter how much money I might have, and even if able to build an expensive brood-mare barn, I would build sheds and winter the mares that way. With this arrangement the mare gets out at all times during the winter and takes her natural exercise. On account of this exercise she will have stronger and straighter foals than otherwise and the mare is less liable to be injured as she sometimes is when passing through stall doors. During the last fifteen years at Village Farm the mares were wintered in sheds and we were very successful with them. One spring there were one hundred and two brood-mares on the farm, many of them outside mares left to be wintered. Out of this number one hundred and one had foals. This success was in no small degree due to the care they received at the hands of Michael and Joseph Fisher, now of Snydersville, N. Y. When mares are kept in sheds it makes less work 


\section{BREEDING THE TROTTER}

for the brood-mare men. One winter at Village Farm one man looked after seventy-eight mares.

The brood-mare shed should vary in length according to the number of mares to be housed. Allow ten feet to each mare. The shed should, ordinarily, open to the east, thus the mares will get full benefit of the morning sun and be protected from the prevailing winds. Local weather conditions might alter this plan and the stable open preferably to the south or southwest. A manger should be built the entire length of the shed. It should be twenty-four inches wide at the bottom, forty inches wide at top, thirty-six inches high. The manger should be made of plank, built tight to hold grain, and should be raised about eighteen inches from the ground. On each side of the posts supporting the front of the shed should be nailed a triangular piece of plank, four feet high and twelve inches wide, the base of the triangle resting on the ground. This keeps the mares away from the posts and there is less danger of their injuring their hips.

On the south end of the shed ten box stalls, fourteen by fourteen, should be built. These may be used either in foaling or for sick mares, which need immediate attention, or for cross mares.

In front of the shed should be a yard extending three hundred feet to the fence. Of course there will be a trough in the yard so mares can drink whenever they desire. 


\section{BREEDING THE TROTTER}

\section{THE FARM SUPERINTENDENT.}

Now, unless you are a practical horseman, or even if you once were a horseman and your knowledge of horses has been lying dormant for years while you were accumulating a share of the world's goods, the next thing for you to do will be to select your farm superintendent.

You will be besieged with applications for the position and you may gain the mistaken idea that a competent superintendent is easy to secure. The contrary is the case, which you will see by studying the superintendent's requirements, as set forth in detail in the chapter on "Management of Stock Farms."

A farm that has been laid out as directed will come close to being an ideal one. Naturally, there are minor details which can best be left to the owner's good judgment. 


\section{Chapter Four}

\section{THE STALLION}

Purchasing a Premier-Over-developed Sires.-Concrete Examples. - Almont Jr.-Almonarch.- Natural Speed.Blood Lines. - The Stallion's Sire - The Stallion's Dam.The Stallion's Individuality. - My Ideal Stallion. - Trotter vs. Pacer. - Shall the Stallion be Raced? - The Stud Season.Care of Stallion.-Feeding.-Covering the Mare.-The Breeding Pen.- Trial Sheet and Stud Book.

FTER having selected a site for your stock
farm, purchased the land, laid out the to appear before the world as a breeder. You will be warmly welcomed, for horsemen are loyal to one another. The turf press, to encourage you and perhaps in anticipation of your becoming one of their advertising patrons, will say nice things about you. Everything will look rosy, but your troubles have just begun.

\section{PURCHASING A PREMIER.}

After engaging your superintendent, if you are to have one, the next thing to do is to purchase a stallion to head your stud.

You will have many advisers anxious to assist you in making your selection. If the advice comes from experienced horsemen, give it heed, but do not hesitate to exercise your own judg- 
ment, for you are now at a very critical point in your career as a breeder.

If you make a mistake in selecting your stallion and his produce fail to fulfil your expectations, it will mean a loss of time and money, and be a matter of constant regret. If you do make a mistake in your stallion dispose of him as soon as you discover it, rather than hang on, hoping against hope, and finally becoming so disappointed as to cause you to give up in disgust.

\section{OVER-DEVELOPED SIRES.}

Above all things, do not join that mad scramble of young breeders anxious to secure a stallion that has been prominently before the public as a racing machine for several seasons. Such racing has sapped his vitality and has taken from him something nature cannot replace. It is sometimes advisable to race a stallion one year so that the public may decide whether or not he is game, good-gaited and has speed to transmit. The stallion should not be raced hard during this one season. Two or three good races are sufficient.

Before continuing my advice on the selection of the stallion, let me say that my views against severely campaigned stallions as stock horses are very decided and have been gained through actual experience.

\section{CONCRETE EXAMPLES-ALMONT JR.}

The year following Almont Jr.'s retirement from the turf, after being almost drilled to death, 


\section{BREEDING THE TROTTER}

he got only forty per cent of his mares with foal. The following season the percentage was sixty and the next year seventy per cent, and in time he became a sure foal getter, which he had been previous to his hard racing campaign. Later, when his produce came on, it did not surprise me to find that his best performers were sired before his severe training and racing season, although he attracted the best mares after his reputation as a race-horse was established. The good performers that were sired after his retirement were foaled several years after the severe campaign of $\mathrm{I} 88 \mathrm{I}$. The following is the list of Almont Jr.'s fastest performers gotten before I88I, with the year indicated in which the dam of each was covered, viz., Belle Hamlin (2.I $23 / 4$ ), I 878 ; Globe (2.I43/4), I 880 ; Maud T. (2.191/4), I 876 and Justina (2.20), (2.I3 to pole), I878. The following is the list of the fastest performers gotten by Almont Jr. after I88 I : Wardwell (2.15), I882; Ovid (3) (2.151/2), I 888 ; Glendennis (2.I $71 / 4)$, I 885 ; Play Boy (2.I 81/2), I884, and Lucretia (2.20), I884.

\section{ALMONARCH.}

I noticed the same thing in connection with Almonarch $(2.243 / 4)$. His season of 1883 on the Grand Circuit was a severe one, and most of his races were long-drawn-out affairs. In 1885 I had him in charge and he was a well worn-out stallion. He was bred to forty-two mares and got but fifteen foals. The following season he stood on the farm of J. D. Yeomans, East Aurora, N, Y, and I 


\section{BREEDING THE TROTTER}

watched the outcome closely. He was bred to fifty odd mares and got about thirty foals. In I 887 he was bred to sixty-two mares and got about forty-five foals. After that time, with rest and care, he proved as sure as the average stallion. Previous to his severe campaign he had been a very sure foal getter. The dam of Topsey (2.091/2), Almonarch's fastest trotter, was covered twelve years after his retirement. Homora, the dam of Fantasy (2.06), and Satory, the dam of Mandolin (2.I6) and grandam of Dare Devil (2.09), were both gotten in I88I, before the severe campaign. The register gives Satory as foaled in I884. This is incorrect, she was foaled in 1882 . Her dam, Mollie O, produced Golconda, by Mambrino King, in 1884 .

Almont Jr. and Almonarch are two good examples of the deteriorating effect a severe campaign has on a stallion for from three to five years afterwards. I know of a number of other stallions which could be cited as examples, but the reader may draw his own conclusions. Mention could be made of many hard-raced stallions to which breeders flocked, after those horses had made arduous Grand Circuit campaigns, that have not proved successful sires, or did not, until many seasons after their retirement from the turf. Of course there are exceptions to all rules and once in a while you will run across a fast trotter gotten by an over-developed sire soon after his retirement from the turf. Such a trotter is often found to be from a mare of great vitality or was 


\section{BREEDING THE TROTTER}

sired by a sluggish horse which would not, of his own accord, race to his limit and would thus save himself some.

The experience gained from watching the produce of Almont Jr. and Almonarch after their severe campaigns was of great interest to Mr. C. J. Hamlin. After studying the matter he became so prejudiced against developed sires (by that he meant those raced excessively) that he never hesitated to express his views in print, as has been noted in a previous chapter.

I have wandered somewhat from my subject, but I consider this phase of the breeding problem important. It is something to consider in selecting your premier stallion.

\section{NATURAL SPEED.}

Do not understand me to mean that because I do not fancy over-developed sires I do not want speed in a stallion. I want all the natural speed I can get, the more the better, for if a stallion does not have natural speed he cannot transmit it to his progeny. As previously stated, in order to satisfy the public I do not object to a stallion's speed being developed up to a certain point.

\section{BLOOD LINES.}

Having decided whether or not you want a developed sire you must give some attention to the blood lines of the different stallions which you have in mind. 


\section{BREEDING THE TROTTER}

I would not presume to limit you to any particular blood line for there are many successful strains.

\section{THE STALLION'S SIRE.}

I prefer the sire of a stallion to be a horse known to possess great natural speed and descended from a line of stallions known to possess great natural speed. If the sire of the horse which you are considering was raced severely and campaigned to death, I advise you to make sure his son was gotten either before his severe campaigns or from three to five years after his retirement from the turf. The sire of your stallion, if old enough, should be a successful producer of speed, and in all events descended from a line of successful producers of speed. By a successful speed-producing sire I do not mean a horse that has sired a large number in the 2.30 list with but a small percentage of good race-horses, nor a sire that has sired just one or two fast performers. A truly successful sire is one that gets a fair proportion of speed from every crop of colts. The best way to compare sires is by the amount of money their produce win at the races. The time is bound to come when more attention will be given to statistics in this direction and less attention will be paid to the number of a horse's 2.30 or 2.20 performers. The sire of your stallion should be a beautiful horse and the sire of beautiful horses. The farther back the stallion's paternal ancestors have combined beauty and speed the better. 


\section{BREEDING THE TROTTER}

If you find a stallion that fulfils requirements on the sire's side you must turn to his dam.

\section{THE STALLION'S DAM.}

The stallion's dam should be a beautiful show mare known to possess great natural speed. The farther back her direct maternal ancestors fulfil the same requirements, the better. I do not object to a mare that has been raced enough to demonstrate to the public that she has speed, and thus benefit her sire and dam; in fact, I prefer it. However, my objections to over-developed dams are as deep rooted as my objections to overdeveloped sires.

The dam of your stallion should be as nearly a perfect individual as possible. If choosing for myself I would want her to be like my ideal broodmare which I describe in the following chapter. If the dam of the stallion under consideration is old enough, her produce should have shown speed. If the stallion is from a young and untried mare I should prefer him to be her first or second foal. In the long run these are a mare's best foals. This subject is treated more in detail in the next chapter. The previous remarks as to the pedigree of the sire of your stallion can be applied to the pedigree of his dam.

\section{THE STALLION'S INDIVIDUALITY.}

If from your original list of available stallions you have found one that fulfils the pedigree requirements you must pass on to his individuality. 


\section{BREEDING THE TROTTER}

As to size I prefer a stallion about I 5.2, but, all other things being satisfactory, his size might range anywhere from I5.I to 16 hands. The majority of the most successful sires stand about I5.2 hands. Only a small percentage of the I6hand stallions become great sires. There are too many blanks at that height. A comparison in the human race is the weight of the greatest men, more of them weighing one hundred and fifty pounds than two hundred pounds.

The stallion should have a beautiful masculine look in all his actions; an impressive, clean-cut head and a long neck, with great width between expressive eyes. The eyes I prefer to be hazelcolored. He should be full-chested, well-muscled and carry a beautiful waterspout tail at all times. In color of coat I prefer a seal brown. There are fewer blanks in that color. The next colors in order of preference are dark chestnut (not sorrel), bay and black.

I prefer as little white marking as possible, although there are many good horses with white legs. I do not object to a star and hind ankles white. Many people object to a great deal of white about a horse because such animals are hard to mate. Others object to white hoofs, but I consider that nonsense. I do not think white hoofs are any more brittle or thin-shelled than black ones. You find such hoofs of both colors.

The stallion should have plenty of substance and be a horse of quality. He should have good bone, the very best of legs and feet and perfect 


\section{BREEDING THE TROTTER}

hocks. I insist on strong hocks for they are usually a horse's weakest point. There are three things my ideal stallion must possess : good looks, good eyes, and good hocks.

As to action the stallion must have plenty of it, a nice round stroke, but he must not be choppy gaited. The greatest trouble with many trotters is, they have not action enough in front to get out of the way of their hind feet. There is something impressive about a horse with an even, unchangeable stride.

The stallion should have plenty of natural speed, so that he may be hitched at any time, go out for a brush and show within a notch or two of his speed without making any fuss about it or asking to be excused.

\section{MY IDEAL STALLION.}

My requirements may be very exacting, but if they are satisfied the horse will be nearly perfect. The horse which in my experience came nearest filling the bill was Prince Regent (2.161/2 to high wheels). He was a son of Mambrino King and the first foal of Estabella, the dam of Heir-at-Law $\left(2.05 \% \frac{3}{4}\right)$, etc. Prince Regent died in the spring of his seven-year-old form, just previous to commencing his stud season. Sixtyfour mares had been booked to him that year at five hundred dollars. He sired twenty-three foals, of which nine have standard records averaging 2.16, including Bright Regent (2.061/4), Emily (2.II), etc. 


\section{BREEDING THE TROTTER}

Had he lived I think Prince Regent would have been one of the greatest sires the world has ever known. Village Farm refused offers of fifty thousand dollars for him on two different occasions. .

\section{TROTTER VS. PACER.}

It will be noticed that in speaking of the stallion to head a newly established farm I have mentioned only a trotter because where a man wishes to purchase but one stallion I would advise buying a trotter. You can secure better paying patronage with a trotting stallion and you will get enough pacers from him. So many breeders give you that knowing smile when you speak of breeding to a pacing stallion. The good trotters are harder to get, and they are better liked by wealthy patrons, who support the breeding industry.

SHALL THE STALLION BE RACED?

After purchasing the stallion you must decide whether or not to race him. I have given my reasons for not wishing a horse to be raced excessively and said that it is advisable sometimes to race the stallion one season in order that the public may have a chance to judge of his gameness and speed. If you are to race the stallion, place him in the hands of a competent trainer. Do not try to economize at this point and give him to a cheaper, but less experienced, man, who may injure your horse for life. Do not race the horse too hard, even in the one season you are to cam- 


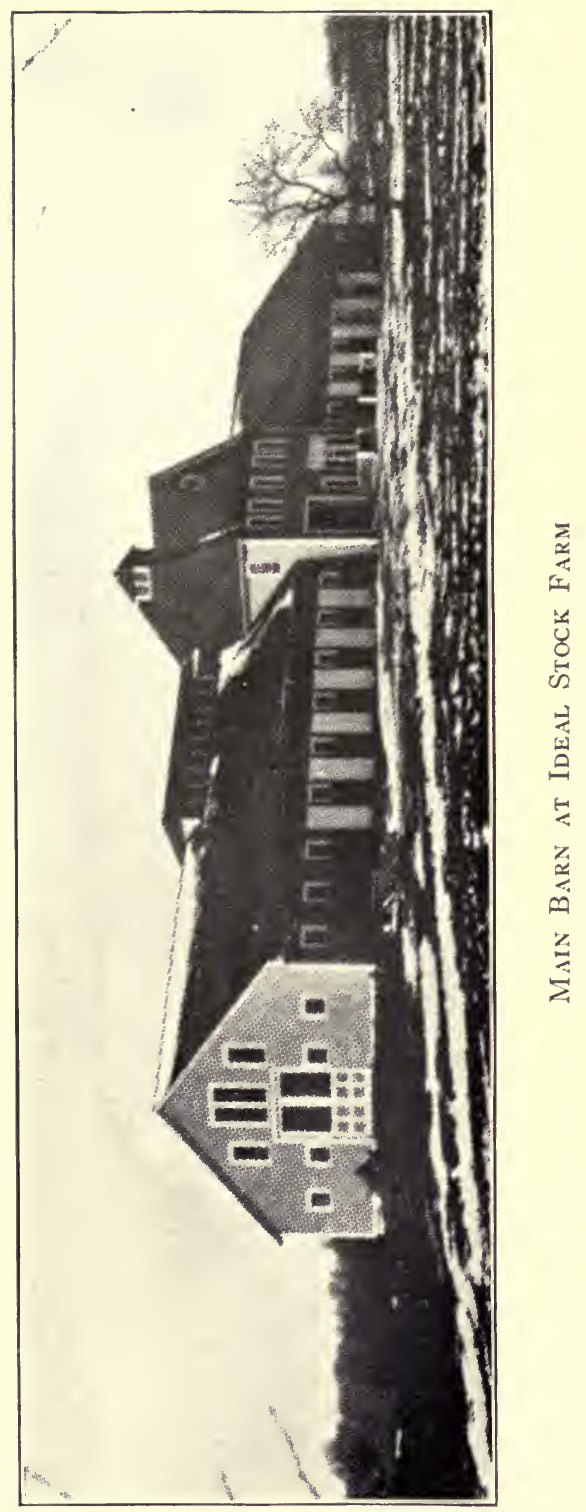





\section{BREEDING THE TROTTER}

paign him. Three or four good races are preferable to a season of ins and outs. You can escape a possible chance of racing-out your horse by giving him a time record, but this opens an opportunity for the "knockers" to claim he is not game.

\section{THE STUD SEASON.}

We have now arrived at the stud season. If you have selected a good stallion there will be several outside brood-mare owners anxious to breed their mares to your horse and you should try to interest more. Many stallions pay for themselves in their first stud season. Remember that you are in the same position as a merchant with goods to sell and do not therefore be afraid to advertise judiciously. Always patronize a few of your local papers, including nearby horse papers, according to the good they can do you, and by all means advertise in at least one or two turf journals of national reputation. This keeps your horse before the general public, and will not only secure you enough extra mares to pay for your advertising but will augment the reputation of your stallion and increase the selling price of his colts, when they come on, and that is one of his best advertisements. Work every legitimate scheme to interest brood-mare owners, but do not "knock" the rival stallions. Enter every mare you breed in the futurities. Enter in all if you think you can afford it, if not, divide the entries among them. Ask your brood-mare patrons to 


\section{BREEDING THE TROTTER}

enter their mares. The more mares in foal to your stallion that appear in the futurity entry books, the more advertising the horse receives. A futurity entry materially increases the value of the foal and the more high-priced colts by your horse that are sold, the quicker he reaches the top. Nothing helps a young stallion more than to have it known that you are breeding some of your best mares to him. You might as well find out from the first crop of foals whether your stallion is a success or not.

\section{CARE OF STALLION.}

In preparing the stallion for the stud season he should be jogged every day except Sunday, when he should be walked for half an hour and grazed when there is grass. The horse should be jogged early, before eight o'clock, so that he will be ready for visitors.

My method of jogging stallions is to jog them four miles on Monday, eight on Tuesday, four on Wednesday, eight on Thursday, four on Friday, and eight on Saturday. This was the practice at Village Farm, where the stallions lived to a hale old age.

I prefer that most of the time the stallion be jogged on the road, taking a different route on different days. Twice a week he should be jogged on the track. Let him brush through the stretch, say a quarter in thirty-four or thirty-five seconds, but never urge or force him to his limit. Stallions like the brushing and delight in it. 


\section{BREEDING THE TROTTER}

FEEDING.

Great care should be taken in feeding all animals, particularly stallions, which are more sensitive than mares or geldings. Horses should be fed very regularly. Feeding time should not vary ten minutes from a stated hour. The stomach is a sensitive organ and soon becomes educated to expect food at certain hours. If that expectation is regularly gratified the animal thrives better. My method of feeding horses is : morning feed at 5.45; noon feed at I I.45, and night feed at 5.30 in winter, 5.45 in summer.

The amount of food to give a stallion, except during the stud season, is about three quarts of oats in the morning, two quarts of crushed oats and two quarts of bran at noon; three quarts of boiled oats, one quart of bran and one tablespoon of oil meal at night. The stallion should have from fifteen to eighteen pounds of hay each day the year round. He should be given a light feed of hay (say five pounds) in the morning, the balance in the evening.

After the stud season commences, about March I, I add two quarts of boiled barley to the evening feed. The barley strengthens the stallion in flesh and semen and makes him a surer foal getter. During a heavy stud season mix a half dozen fresh, raw eggs with the evening feed.

The stallion should be watered before feeding. Let him drink all he wants. Water him after feeding also. 


\section{BREEDING THE TROT'TER}

COVERING THE MARE.

We now come to the actual act of breeding. I advise that the stallion visit the mare after four o'clock in the afternoon, or even after six. It is quieter then, and neither mare nor stallion is so liable to become uneasy and excited.

The stallion should be led to the breeding pen as quietly as possible, to avoid nervousness. Everything should be ready. Do not keep him waiting. I would advise hobbling the mare on all occasions in order to protect the horse from fright and accident. If the stallion is slow to cover he should be treated as set forth in chapter eleven. Treatment for masturbating is also given in the same chapter.

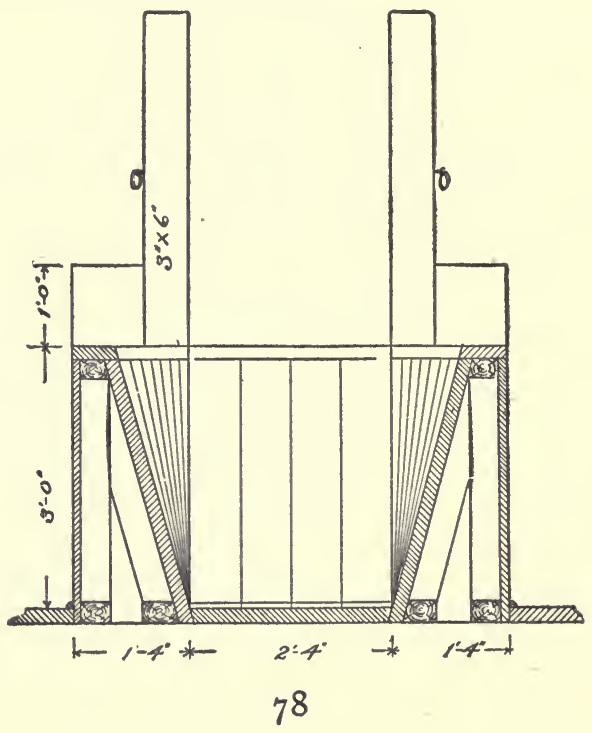



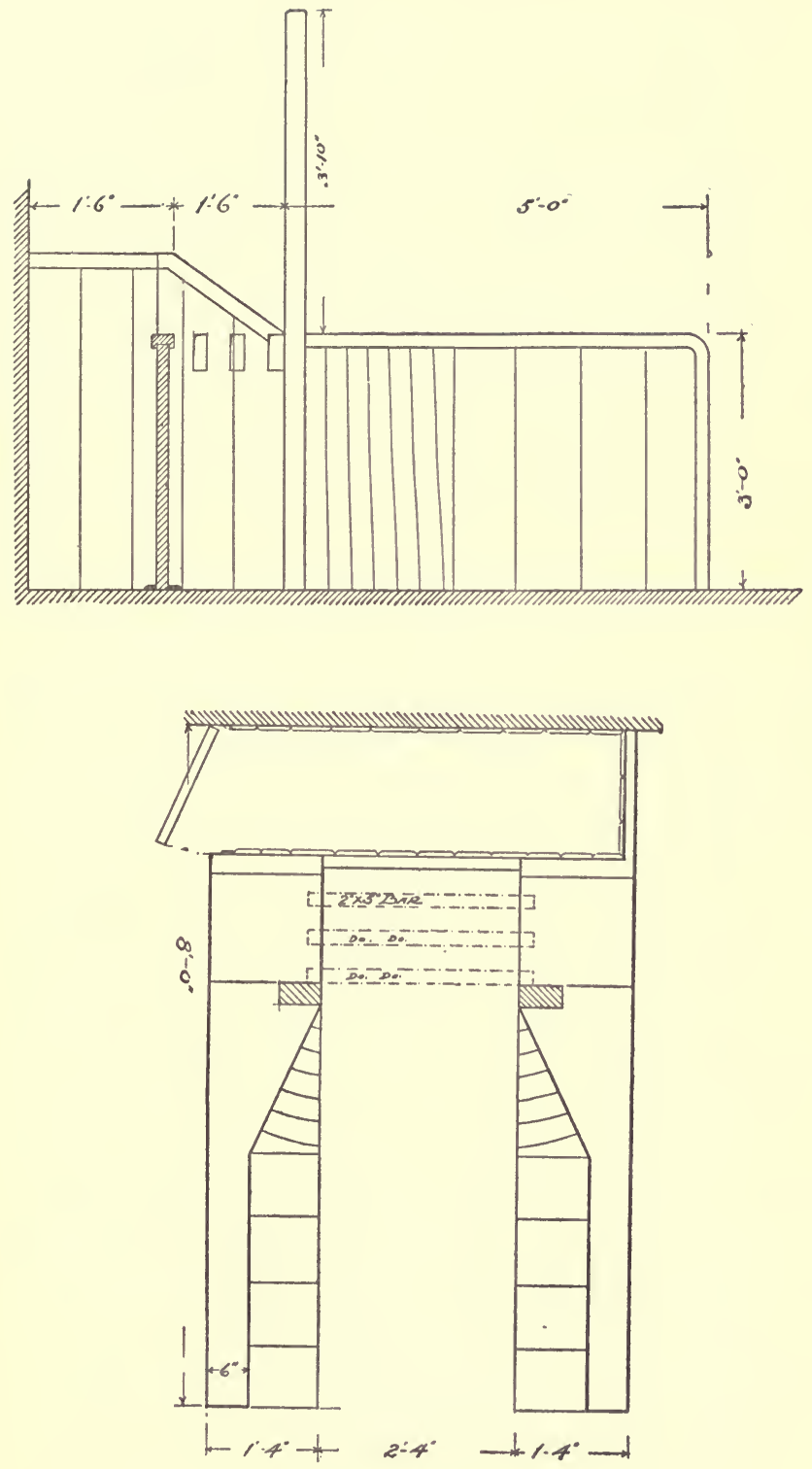


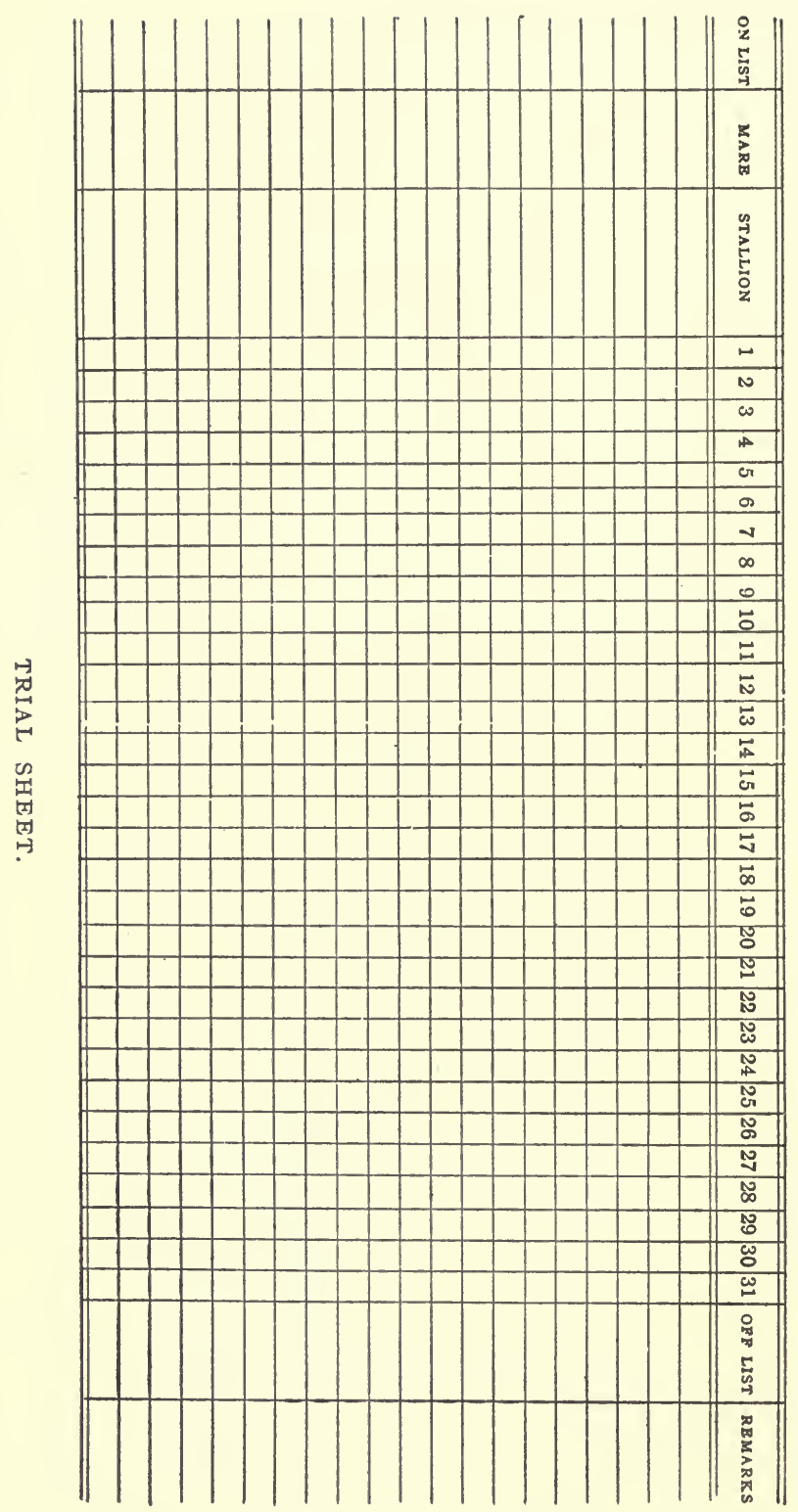




\section{BREEDING THE TROTTER}

\section{THE BREEDING PEN.}

Plans are presented herewith for what I consider an ideal breeding pen and one which allows the colt to be kept in front of its dam while she is being served. The colt's pen should be padded. By the use of bars in front of the mare the pen can be shortened or lengthened, according to her size. The inside of pen is one foot four inches wider at top than bottom.

\section{TRIAL SHEET AND STUD BOOK.}

Great care should be taken in transcribing the records of services. You should keep a trial sheet and a stud book. On preceding page is reproduced the form I prefer for a trial sheet.

Enter every mare on the farm on the trial sheet and opposite each the name of the stallion to which she is to be bred. After the first service compute the next trial day, as explained in the following chapter, and enter it on the sheet, indicating the number of days that will have intervened since the service. For instance, if your mare was bred on March I, in column nineteen you should enter the word March, and the number eighteen to indicate that on March Ig the mare is to be tried, which will be eighteen days after being bred. If she refuses, then under column twenty-two you should enter the word March and the figure 2 I to indicate that on March 22 the mare is to be tried, which will be twenty-one 


\section{BREEDING THE TROTTER}

days after being bred, and so on till the mare proves with foal.

I prefer the following form of a stud book :

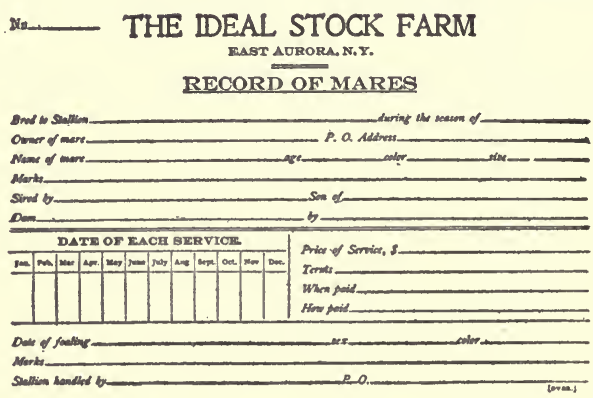

If the mare is an outsider furnish the owner with a duplicate of the above form, properly filled out, on the back of which is the following form :

\section{IMPORTANT}

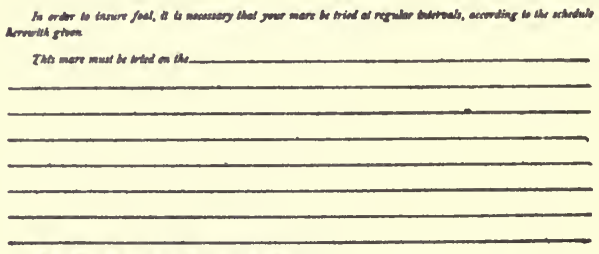

Bring thie with you overy tima you bring the mark.

2E SURE TO PRESERVE THIS CERTITIEATE. 


\section{Chapter Five}

\section{THE BROOD-MARE}

Best Way to Purchase Mares.-The Ideal Brood-Mare.Pedigree.-Care.-Preparing for the Foal.-Care of Mare and Colt after Foaling.-Breeding the Mare.-Care of Mare and Colt in the Pasture.-Weaning the Colt.-Mare on Winter Diet.- Age at which to Breed.-Developed Mares.-Inbreeding.-Selecting a Mate.-First Impressions.-Importance of Natural Speed.

$\mathrm{H}^{\prime}$

AVING founded your stock farm and purchased your stallion, let us now consider the purchase of brood-mares.

As soon as it becomes known that you are in the market for mares you will be besieged with letters from brood-mare owners in such numbers that you may be led to the erroneous conclusion that all brood-mare owners are anxious to sell. If you "follow up " each letter you will lose much time and spend a considerable but useless amount in railroad fares, for it is inconceivable that every mare offered will suit you.

\section{BEST WAY TO PURCHASE MARES.}

In many respects the best way to purchase your brood-mares is at auction. By purchasing at auction you secure the mares at the public valuation; you get them all at once, and are not put to the expense nor risk of shipping the mares to your 
farm from all parts of the country. If you conclude to buy your mares at auction watch the sale announcements closely, especially dispersal announcements of farms going out of existence, for their best mares, not the culls alone, will be offered. It is always advisable, if you are interested in a particular consignment, to visit the farm about two weeks before the sale and look the mares over carefully. If you wait till a mare enters the sale ring you may, in the excitement of bidding, buy something you would not have purchased had you given her careful inspection.

If you examine the mare at the farm you will probably have an opportunity to see some of her produce, the kind of gaited colts they are, the stallion she breeds best from, and will discover whether or not she is a regular breeder and a good brood-mare.

With these preliminary remarks as to the manner of purchasing mares, I will pass to a consideration of the sort of mares most likely to prove successful as a producer of speed.

\section{THE IDEAL BROOD-MARE.}

My ideal brood-mare should stand from $I_{5}$ to I 5.3 hands; should have a clean-cut head, fine ears, and expressive and intelligent protruding eyes (not dull nor sunken), which indicate kindness and will-power,-ideal traits in a brood-mare. The neck and throttle should be clean-cut. I prefer a neck of medium length, neither too long nor too short. The shoulders should not be straight, 
but oblique and heavily muscled. The legs should be flat and fluted, skin not too thick, and feet good. The mare should stand perfectly straight both in front and behind. She should have a deep chest. Her back should be short; her barrel roomy and well ribbed; her quarters beautiful, smooth and round, with heavy muscles running well down to the hock. As in the stallion, it is important that the mare have the best possible hock, with no sign of coarseness. An ideal hind leg is one along the back of which a straight edge could be laid so as to bring the hock, pastern and point of ankle in the same straight line. The mare should carry the same beautiful tail advocated in the previous chapter. In general conformation the mare should be full but neither too heavy nor too light.

\section{PEDIGREE.}

As to her pedigree, the remarks on the stallion's blood lines are applicable here. It might be added, however, that a mare that is a member of what is known as a "brood-mare family" that is, a mare with a direct line of productive maternal ancestors, stands a better chance than any other of becoming a successful producer herself.

\section{CARE.}

After securing your mares you should see that great pains are taken to care for them properly while on their way to your farm and after their 


\section{BREEDING THE TROTTER}

arrival. The better health the brood-mare enjoys the better foal she will produce. She should be kept in the best possible condition the year round. By that I do not mean that she should carry a lot of flesh, because a fleshy mare is liable to cramp her foal and it will come small, crooked and weak. There is a happy medium. I prefer to have the mare a trifle thin than too fleshy.

The care of a brood-mare is not a subject that can be treated at random. We must start at some period of her existence and follow her through a year of the attention she requires. It would be natural, perhaps, to start with the act of mating her with the stallion and follow her through a year till she foals. However, I intend to treat the mare from a standpoint slightly different. So many mares are purchased when already in foal that I shall take up the mare just previous to the time of foaling and speak of the care she and the colt should receive up to the time the foal is weaned. At this point the weanling will be dropped and its further care treated in another chapter. I will continue with the mare, however, during the winter up to the point when she is again ready to foal. In the proper place mention will also be made of the correct time, after the mare has foaled (nine days), to breed her again. I will also outline the method of trying mares in practice at Village Farm. After these practical points have been covered I will devote a little attention to some of the general theories of breeding. 


\section{BREEDING THE TROTTER}

PREPARING FOR THE FOAL.

When the time approaches for the brood-mare to produce her foal a box stall sixteen feet square should be bedded down for her, with the bedding a little higher around the edges of the stall than elsewhere. The sides of the stall should be perfectly smooth. There should be no hay rack, while the feed box should be detachable and taken out after each meal. As the day of foaling approaches the mare should be fed moderately.

The mare should be taken up and placed in a stall at about ten months and twenty-five days after being bred.

The period of gestation varies. As a rule old mares carry their foals longer than young mares. One mare on the Village Farm carried her foal twelve months and fifteen days. The period of gestation often varies in families and is a characteristic thereof. Estabella, and most of her descendants under my observation, produced at just eleven months. The average period is computed by various authorities at from eleven months and ten days to eleven months and twenty days.

About forty-eight hours before foaling, the mare's udder will fill up, wax will form on the nipples and it will be plainly noticed that the pelvis has relaxed. When the mare reaches this condition an attendant should remain with her, in order to render any assistance the mare may require in foaling and to help the colt to its feet 


\section{BREEDING THE TROTTER}

so that it may suckle if it be too weak to do so unaided.

CARE OF MARE AND COLT AFTER FOALING.

Shortly after the colt arrives it should suckle or if too weak should be assisted to do so, for the first nourishment will strengthen the colt very much. After the colt is once able to stand on its feet alone and suckle the next thing is to make sure that its bowels are working regularly. If you find they are constipated you will have to make an injection of warm water and sweet oil, proportions one ounce of the sweet oil to about one quart of water.

After foaling, the "after birth" should be placed in a basket kept purposely for this use, carried at least ten rods away from all stables, sprinkled with quicklime and buried.

In case of abortion the mare should be removed to a separate stable distant from other mares. Her hind parts and tail should be washed with soap and a solution of two gallons of warm water, two ounces of creoline and one-quarter ounce of carbolic acid. The aborted foal should be buried with quicklime. Be very careful when this is done. A careless employee at Village Farm once buried aborted twins in a manure pile and before his carelessness was discovered some forty odd mares had lost their foals.

In the morning after foaling, for this generally takes place at night, the stable should be thoroughly cleaned and disinfected with creoline or carbolic acid. The bedding should be removed 


\section{BREEDING THE TROTTER}

and fresh bedding laid down after sprinkling the floor with air-slaked lime. From this time, and for the next three weeks, the stall and bedding should be kept scrupulously clean, lest the colt have navel trouble. Navel trouble is caused by the colt coming in contact with the filthy straw in struggling about to get up. If the colt is affected you will notice, when it is a few days old, that it acts dull and is sore and stiffened in certain parts, such as knees, hips, or hocks. On examination you will find there is a leakage from the navel cord. In this event the colt should be treated at once, as set forth in chapter eleven.

Within twenty-four hours after the mare drops her foal, and before she is allowed to come in contact with other mares, her tail and all under parts should be thoroughly washed with a solution of warm water and creoline or carbolic acid.

When the colt is from seven to nine days old it may be troubled with scours or dysentery caused by the mare coming in heat. If this occurs keep both mare and colt as quiet as possible. Give the mare Humphrey's Specific AA until after the twelfth day and reduce her grain at least one-half. Give the foal Humphrey's Specific FF, also blackberry cordial, recipe and directions for use of which will be found in chapter eleven. The same condition may be noticed when the mare comes in season at thirty days, but by this time the colt should be strong enough to go through the period without any ill effects. If the trouble should become chronic, however, take the mare from the 


\section{BREEDING THE TROTTER}

pasture and keep her in a cool, quiet place and cut off her grain and feed her nice hay or grass from four to seven days till the colt's bowels are normal.

As soon as the colt is strong enough, and if the weather is good, the mare and foal should be turned out in a paddock from one to two hours in the morning and between three and five o'clock in the afternoon.

\section{BREEDING THE MARE.}

If the mare and foal have had no mishaps the mare should be bred again on the ninth day after foaling.

Take the mare to the breeding barn and find out by the aid of a teaser if she be in heat. Do not let the teaser annoy or excite her. If she is ready to breed let the stallion cover her. Keep both mare and stallion as quiet as possible, avoiding all excitement. Plans for a breeding pen, to hold mare and colt, were given in chapter four.

It is better to have a place for the colt in the breeding pen in front of the mare. The colt is quieter than if kept alone or held by a man and the mare is quieter if she sees the colt in front of her.

After the mare has been bred her next trial days are in succession, eighteen days after foaling, twenty-one days after foaling, twenty-five days after, thirty days after, thirty-three days after, thirty-seven days after, and forty two days after foaling. After this she should be tried on Tues- 


\section{BREEDING THE TROTTER}

day and Friday or Saturday of each week till ten or twelve weeks have passed since breeding. The trials from the eighteenth to the thirty-third days after foaling are important ones. If the mare stands these trials it is safe to say that she is with foal. If the mare comes in season on any of these trial days she should be re-bred and the process of trying repeated.

In case you have any trouble in getting the mare with foal and if it is feared that she may be barren she should be treated as mentioned in chapter eleven.

\section{CARE OF MARE AND COLT IN PASTURE.}

We will now return to the mare and her young colt. As soon as the weather is fit and the nights warm the mare and the colt should be turned into pasture. If the mare does not thrive that way she should be taken up at ten o'clock each morning and fed two quarts of crushed oats mixed with two quarts of bran. She should also be given a small quantity of alfalfa or green corn. About three o'clock the mare should have a feed of from two to four quarts of the mixture already mentioned, without the green stuff. About five o'clock she should be turned back into the pasture for the evening.

Too many mares should not be kept in one pasture. As mentioned in chapter three it is advisable to divide them among ten-acre pasture lots rather than allow all of them to run together.

Towards the middle of the summer the colts 


\section{BREEDING THE TROTTER}

will require additional nourishment to what they receive from their dams. As mentioned in chapter three, feeding paddocks will be necessary for the colts. They should be located in as high a spot as possible. The paddocks should be thirty-two feet long and sixteen feet wide. The pasture fence will form one side of the paddock. To form the other three sides set in posts eight feet apart and along the top of the posts (about fortysix inches from the ground) nail boards eight inches wide, one and one-half inches thick, and sixteen feet long. This will allow the colt to walk under the fence and yet will exclude the mares.

In the centre of the paddock should be built a trough twelve inches wide, six inches deep and about twelve feet long, raised about four inches from the ground so that air can pass under. The troughs should be lined with zinc. This will enable the attendant to keep the troughs clean and sweet and free from musty feed.

The colts should be fed once or twice a day, according to your own judgment, but do not feed any more at one time than the colts will eat up clean. I prefer a mixed feed of the following proportions : oats, two bushels; wheat, one bushel; corn, one-half bushel; bran, fifty pounds ; oil meal, twenty pounds.

By oil meal I do not mean oil cake but ground flax-seed meal. This feed should be thoroughly mixed. If the colts should leave any feed, throw that away or feed it to the pigs, and clean the trough before feeding again. 


\section{BREEDING THE TROTTER}

Be sure to salt the mares and colts, in fact all horses on the farm, once or twice a week.

\section{WEANING THE COLT.}

We may now pass over a month or two, during which the mare and foal will ordinarily be doing well on pasture. Weaning time approaches. When the colt is five months old it should be weaned.

The mare should be taken to the brood-mare shed and the colt to some stable so far away that it cannot hear its mother, and vice versa. The colt should be placed in a stall with a detachable feed box and without a manger. It will naturally be uneasy when first taken from its mother and every effort should be made to keep it from fretting, otherwise it will lose flesh.

I advise weaning the colt in the morning. The same afternoon, between four and five o'clock, the colt should be allowed to suckle for about thirty minutes. For the next three days it should be allowed to suckle twice a day, in the morning between six and eight, and in the afternoon as already mentioned. After the third day it should only be taken to the mare in the afternoon. This should be continued for four to six days, after which the mare should be milked once or twice a day until she has thoroughly dried up. If there is fever or inflammation in the udder feed bran mashes, see that the mare gets plenty of exercise and give her Humphrey's Specific AA three or four times a day. In some cases hot applications may be necessary. 


\section{BREEDING THE TROTTER}

After the colt is weaned the mare should be turned into pasture again and remain there until time to take the mares up for the winter, which in some seasons will not be till November $\mathrm{I}$ or $\mathrm{I} 5$. If the mare does not thrive well on pasture after the colt is weaned take her up and feed as directed for winter feeding.

As soon as the colt is weaned it should be fed for the first month five times a day as much of the mixture it ate in the feeding paddock as it will clean up at one meal.

\section{MARE ON WINTER DIET.}

When the mare is finally taken up she should be put on a winter diet. Feed her morning and evening three quarts of a mixture composed of two-thirds crushed oats and one-third winter wheat bran. Give her all the hay she will eat. The hay should be clean and not musty. I prefer hay that is half timothy and half clover. She should also be fed at noon a pint of winter wheat with which has been mixed a pint of cotton-seed meal. This is done as a preventive of abortion.

I have attempted to give directions for a mare's care from a time in the spring just previous to foaling till she is on winter diet and is being carried along carefully with the expectation of her foaling again.

AGE AT WHICH TO BREED DEVELOPED MARES.

Before leaving the brood-mare, mention should be made of certain practices of breeding which are 


\section{BREEDING THE TROTTER}

important to consider. One of them is the age at which the mare should first be bred. At this point, if you have a young mare, it will be necessary for you to decide whether or not you wish to race her.

A filly intended for breeding purposes should be broken, trained and her speed developed like a filly intended for racing purposes. If at the age of two or three years she shows speed, is nicely gaited and comes up to your ideal of a brood-mare, it is not necessary to train her longer or to race her in order to endow her with the ability to transmit speed to her progeny. Extended development will not help her colts one particle. A mare inherits a certain amount of speed ability from her parents. She should be developed enough to find out what ability she herself has in that line. If she has no speed ability she will transmit none.

As in the case of stallions it is sometimes advisable to race a mare one season to show the public she has speed and to help her sire and dam, but her racing career should be limited to one season, made as easy for her as possible, after which she should be retired to the brood-mare ranks.

A mare intended for a race mare should not be bred first for the reason that few mares pack together again after foaling. With such mares a hot day and a hard race will develop certain weaknesses that place them at a disadvantage against other horses. A few of our fast performers have taken their records after producing a foal. Emily (2.II) was one of these. If a mare is not to be raced 


\section{BREEDING THE TROTTIR}

I prefer breeding her as a three-year-old or fouryear-old.

\section{INBREEDING.}

A subject of interest to many brood-mare owners is that of inbreeding. It has been said that inbreeding concentrates the vices and weakens the individual. This, in my judgment, is not true if a careful selection of individuals is made.

For example, I once knew a lawyer named James Miller, in whom considerable sporting blood flowed. On returning from a visit to England he brought me a setting of game chicken's eggs which he had secured from a nobleman friend of his. I bred these fowls in and in for sixteen years. They always bred true to feather although not always to size. At the end of sixteen years I had as good a lot of fowls as from the first hatching. I was always careful, however, to mate only the very best individuals.

The American trotter is an example of a race founded by inbreeding. An inbreeding of Messenger blood produced Rysdyk's Hambletonian and Mambrino Chief, founders of our two principal trotting families. The trotter of to-day is the result of inbreeding these two strains with outcrosses to Pilot Jr., thoroughbred, Clay and Morgan.

I do not agree with a foreign authority that the American trotter is too highly inbred. The trotting family has reached its present perfection through inbreeding and would have been still 


\section{BREEDING THE TROTTER}

farther advanced but for the set-back during the Civil War period.

\section{SELECTING A MATE.}

Naturally, every breeder has a preference for certain lines of blood. I am somewhat partial to the "best son of a best son" theory. On pedigree alone I would prefer to cross a mare to a horse descended from Hambletonian through his best sons, George Wilkes and Electioneer, than through any other sons although other sons were successful, such as Happy Medium, Egbert, Strathmore, Aberdeen, Dictator, Harold and Alexander's Abdallah. The latter horse I consider the best son of his sire for his opportunities. So many trotters have come from his few descendants that he himself must have had the requirements of a sensational sire and would doubtless have proved one but for his untimely death.

The average brood-mare owner does not study pedigrees closely enough. The most comprehensive treatment of this subject is S. W. Parlin's book, "The American Trotter," which should be in every brood-mare owner's hands.

When you come to select a mate for your mare do not rush to the stallion most prominent before the public until you are sure he will make a good cross on your mare. Do not judge a stallion by the number he has in the 2.30 list, but judge him by the number of good, successful race-horses he has sired. As an example of crossing two strains of blood let us suppose that you have on your 


\section{BREEDING THE TROTTER}

farm two good stallions, the best sons of their respective sires. We will call one Primo, the other Ideal. It is your desire to establish a family from these two horses. Take your best daughter of Ideal from a well-bred dam. If she is also the best daughter of her dam, so much the better. Breed her to Primo. We will suppose that you secure from this union a beautiful filly with extreme speed, although the chances are it will be a colt, for males generally come when you are looking for the opposite sex. The filly has so many good qualities you are determined to go back to the Ideal blood so you breed this filly to Ideal. If a filly results from this mating she should be bred to some good out-cross. If this is a filly you can breed to Primo again. We once had at Village Farm a filly (The Silent One), by Chimes, dam Silent Rose, by Mambrino King, grandam Beattie Chimes, by Chimes.

\section{FIRST IMPRESSIONS.}

Almost as important to brood-mare owners as inbreeding is the subject of first impressions. I have very often found that a mare's first foal is her best. Without attempting to discuss the matter statistically or scientifically I may say that the majority of veterinarians and doctors with whom I have conversed on the subject believe that the impression of a mare's first mating is stronger than any other; that, therefore, a mare's first foal is likely to be her best one, and that the first impression has a more or less lasting effect on the 
mare and her subsequent foals. If this be true a brood-mare owner should be careful to breed his virgin mare to the best stallion he can select. One veterinarian has said that, all other things being equal, he would choose the mare which had been first covered by the better stallion. It is agreed that the impression is a nervous and not a physical one. I believe one reason a mare's first foal is likely to be better than her others is because she is then very likely to be in better physical condition than at any other period of her existence. The better health the mare and stallion enjoy when they are mated the healthier and stronger the foal, and the higher type horse it will become. The same principle is true with reference to the other divisions of the animal kingdom.

The first foal of Estabella, one of my favorite brood-mares, was Prince Regent, which I think would have been one of the greatest sires the trotting world ever saw. He died in March, I89I, as a six-year-old, just before the stud season. Sixtyfour mares had been booked to him at five hundred dollars. He was a very fast horse and took his record of 2.I61/2, beating Pamlico (2.10) after a stud season. Prince Regent was an equine king and an impressive individual, either at rest or while walking, jogging or racing.

\section{IMPORTANCE OF NATURAL SPEED.}

In connection with my observations on breeding mares I might say that in my experience I have found that the great matrons almost invariably 


\section{BREEDING THE TROTTER}

have a great deal of natural speed, and could show it in the paddock if frightened.

Mr. C. J. Hamlin used to delight in seeing Estabella trot in the paddock. His favorite method of inducing horses to show their speed in the paddock was to step behind them and open and shut a large umbrella with as much noise and flourish as possible.

I remember that Miss Russell, the dam of Maud S. (2.083/4) and Nutwood (2.18 $\left.\frac{1}{4}\right)$, was a great lot trotter. Mr. Hamlin tried to purchase her at one time but was unsuccessful. He offered ten thousand dollars for a two-year-old full sister of Maud S. and eight thousand dollars for the full sister a year younger.

In closing this chapter I might say that I do not agree with some of the old-time authorities who claimed that the brood-mare was merely a shell in which to raise colts. I consider her part in the production of trotters fully as important as that of the stallion. 


\section{Chapter Six}

\section{THE WEANLING AND YEARLING}

Halter Breaking.-Breaking to Bit.-Beside a Lead Pony. -Ground-Breaking.-Hooking to Cart.-Shoeing.-Developing Muscles and Speed.-"Dr. Green."-A Futurity Candidate.-Feeding.-The Yearling.

NE of the greatest pieasures of a trottinghorse breeder comes when the time arrives to break the weanling and continues through the period of its first speed development, for in this way and in this way only can the breeder determine his success or failure.

It will be remembered that in the previous chapter I spoke of the care which the foal should receive from birth up to that point when it is no longer dependent on his dam and is called a weanling.

This chapter will treat of its care and attention from the time that it is first halter-broken until it is technically a yearling.

HALTER-BREAKING.

After the colt has been entirely removed from the influence of its mother it should be halterbroken.

Prepare for the colt a good, strong, five-ring leather halter and put it on carefully. The halter 


\section{BREEDING THE TROTTER}

should not fit too tightly nor too loosely and should be kept on the colt till time to harnessbreak it.

After the halter has been placed on the colt's head snap a strong leather halter strap into the lower ring of the halter. This strap should be one and one-quarter inches wide and two and onehalf feet long. Leave this hanging to the halter so that you can enter the stall at any time and take hold of the colt without frightening it. As the weanling walks around the stall, and when nibbling at the hay, it will step on the halter strap from time to time and find that it cannot raise its head. In this way the colt soon learns that the halter is an instrument of restraint. When the halter has remained on the colt for about a week the youngster will be about two-thirds halterbroken. Its education in this direction may then be completed by leading it from the stall. Ordinarily you will find the colt willing to go anywhere you lead it.

Some men halter-break colts in the open without preliminary wearing of the halter in the stall, but I do not approve of this. I have seen too many colts frightened and injured by rearing away from the halter, to the use of which they have not become accustomed.

If you have a large main barn, with a wide hallway, the best place to lead a colt, after it has worn a halter in its stall for a week, is the hallway of the barn. The attendant should lead the colt up and down the hallway a great many times. When 


\section{BREEDING THE TROTTER}

the colt does this quietly it may be led around a smooth paddock. In time the colt will follow its attendant to any place.

The weanling, at all times, should be petted and treated kindly. It should be groomed carefully each day and its hair straightened out. This will give it a healthy coat, make it feel good and assist its growth.

\section{BREAKING TO BIT.}

When the colt is six months old procure a bridle that fits well and place it on the colt in the stall, as was done with the halter. Use a snaffle bit and see that it fits properly, otherwise it will worry and aggravate the colt. The bit will vary in length from three to three and one-half inches. Keep the bridle on the colt about an hour and a half, both morning and afternoon.

When it becomes accustomed to the bit in the stall the colt is ready for the colt breaker.

\section{BESIDE THE LEAD PONY.}

The colt should first be led to halter on a walk, by a competent man, beside a saddle pony. Half a mile is long enough for the first lesson. This should be repeated daily for about a week or till the colt becomes accustomed to the pony. When this work commences the colt should be turned out about an hour every morning if the weather is fine.

As soon as leading begins the colt should be properly fitted with a pair of light shin boots, as 
protection against injuries which are liable to produce splints and which have laid up and even retired a great many colts. When the colt is turned out I advise putting shin and quarter boots on for protection. The quarter boots used in the paddock should be kept for this purpose only and a different pair used in training.

The following week the colt may be led along on a slow jog and for a short distance some place in the half-mile let the colt move along nearly as fast as it will go. Be sure to keep the colt on a trot and its head straight with the body.

If by this time the colt is leading nicely and shows promise of speed I would advise letting up on the leading for a while. It is not well to force the colt too strenuously.

GROUND-BREAKING.

By this time the colt will be approaching seven months of age and it should then be broken to harness.

Procure a harness that will fit properly and keep it on the colt in the stall from thirty minutes to an hour each day till the youngster becomes accustomed to the strange straps. After that the colt should be driven along the barn hallway or in a smooth paddock till he is thoroughly ground broken and responds to words of command, the most important of which is "whoa." It is equally important that the colt be taught to stand still, particularly after it is hitched. It lessens the pleasure of ownership when you stop 


\section{BREEDING THE TROTTER}

in the road to talk to a friend to find your horse so restless that you have to drive on and postpone conversation till another time. The colt should be taught to back and to turn either to right or to left with as much ease as when going forward. A great many of our race-horses, improperly broken in youth, will turn only in one direction.

After the colt is thoroughly ground-broken procure two light round poles twelve or fourteen feet long and slip them through the shaft holders as though they were shafts of a cart. Rub these poles along the sides and quarters of the colt until it becomes accustomed to them and shows no fear nor excitement. The colt is now ready to hook up.

\section{HOOKING TO CART.}

I do not approve of heavy breaking carts. I advise hooking the colt to a light cart from which one can descend quickly. Take a groom along for the first few times, as his assistance will be needed in case of emergency.

Do not keep the colt hooked up more than thirty or forty minutes a day nor drive it more than a mile a day.

Drive it this way every day for ten or twelve days, by which time the colt should be nicely broken.

\section{SHOEING.}

The colt is now ready to be shod. If the soil is gravelly shoes may become necessary before the colt is thoroughly broken. As to shoeing you 


\section{BREEDING THE TROTTER}

must use your own judgment or consult an experienced trainer or a competent blacksmith; different colts will require different shoes. The naturalgaited trotter will require light shoes; doublegaited colts, shoes that are a little heavier. Some colts will show considerable speed without shoes. Fantasy, when two years old, trotted a quarter in thirty-five seconds without them.

\section{DEVELOPING MUSCLES AND SPEED.}

After the colt is shod if it is doing nicely it can be brushed for a sixteenth or a quarter of a mile each day. By this time it will probably need a pair of quarter boots for protection.

The colt should never be asked to do all it can. Let it keep a little reserve speed. This will encourage the youngster, and it will take hold more cheerfully, and will improve as its education progresses.

When the colt is eight months old go back to leading in addition to the other work. Have the colt led three or four times a week and driven two or three times.

When January $\mathbf{I}$ of the year following that of its foaling arrives the colt will technically become a yearling.

THE YEARLING.

By the time the colt technically becomes a yearling its muscles and speed will be well under way of development. This development should be continued until the middle of May. 


\section{BREEDING THE TROTTER}

\section{METHOD OF DEVELOPING.}

Most of the work given the colt should be beside a lead pony. This will develop its speed more quickly than when hitched to cart and without the attending fatigue. The yearling should be driven to cart some, as indicated, in order to "muscle it up " and make it capable of pulling the weight it will have to draw in later years.

\section{“DR. GREEN."}

Now spring has come and the grass is green and the colt should be turned out to graze for from fifteen to thirty days. "Dr. Green" is the best veterinarian I know of-makes the best "speed elixir" for a colt. After the vacation is over the colt should be taken up and led and driven alternately till the first of September. The colt should be turned into a paddock two hours each afternoon. If the colt is sluggish cut down on its work and let it run out longer each day.

\section{A FUTURITY CANDIDATE.}

If the colt looks like a futurity candidate by September I, I would advise that leading be stopped and all work after that be to harness.

As the nights become cool, say during September and October, the colt will improve rapidly, in fact probably so much it will surprise you. Do not overdo the training, for the colt, above all other things, should never be over-trained.

I would advise you to let up on the colt during 


\section{BREEDING THE TROTTER}

November and December, allowing it to get its exercise in the paddocks.

FEEDING.

A nice feed for yearlings, as well as two-yearolds, is prepared as follows. Boil the required amount of oats and let them steam about an hour, and then mix with them about one-eighth their quantity of good winter wheat-bran and about a tablespoonful of linseed meal to each horse. 


\section{Chapter Seven}

\section{THE TWO-YEAR-OLD AND OLDER}

Winter Work.-Spring Work.-Summer Work.-Turning Over to a Trainer. - Use of Bandages and Washes.-Packing of Feet.-Aged Horses.

$7 \mathrm{HE}$ care of the two-year-olds and colts of older ages is so nearly alike that, except where noted, the advice herein can be applied to all ages.

WINTER WORK.

We left the colt in December of its yearling form. In January of its two-year-old form take it up and jog it carefully.

If, during the winter, sleighing is good, jog to sleigh and, without warming it up too much, let it brush along, say a quarter of a mile. The youngster will enjoy this and the practice will materially develop its muscles and speed.

During the early winter of its two-year-old form you should have your mind made up as to whether the colt is a " colt trotter" or whether it should be prepared for the market. If you decide it will not pay to train the colt any longer the best thing to do is to sell, in which event I refer you to the following chapter on preparing for the sales and the show rings. If, on the other hand, you think 


\section{BREEDING THE TROTTER}

the colt will make a good race-horse as a five-yearold, turn it out till the fall of the year it is coming four years old, when it should be taken up again and turned over to a trainer. During this period the colt should be well looked after and not neglected.

\section{SPRING WORK.}

To return to the two-year-old, carry the colt along with jog work till about March I when the roads will break up and spring arrive. I would advise giving the colt a nice long jog about four times a week.

I would let up on the colt the first of March and turn it out in the paddock for about a month. See that it is well looked after. After the vacation I advise taking the colt up and jogging it for from three to four weeks, preparatory to track work.

Late in April or early in May the weather will be fine, the road and track in good condition, and spring - a beautiful time of the year-is with us. The colt will really ask to go, will want to go, and the impatient trainer, after the tedious winter, is usually anxious to let it go. This is the time when the impatience of horse and driver should be restrained. Go slow with the colt and keep it well within itself. The colt may be worked on the track with short brushes at speed. During the latter part of May or early in June the colt may be driven very slow miles, allowing it to step through the stretch at the last end. 


\section{BREEDING THE TROTTER}

I do not advise repeating the colt before June i 5 or 20 . I would then begin to repeat it slow miles, with the last half the faster and with a brush at the end, but never drive the colt to its limit.

\section{SUMMER WORK.}

About July I the colt is, or should be, in nice, strong condition, with hardened and well-seasoned legs. It is now ready for work a little more severe and for faster repeats. If the colt is speedy and is making speed each successive repeat should be faster, dropping from two to four seconds every work-out.

By August the owner and trainer should be able to judge from the speed shown in the last quarters or halves of work-out miles whether they have a colt good enough to win a portion of the money offered in the futurities.

If the colt as a two-year-old is not good enough it should be turned out about September $\mathrm{I}$ and carried over another year. Take off its shoes and rasp down its feet before turning it out. The colt should be taken in and fed each day as usual and may be kept out over night if the weather is good. After running out a month the colt should be taken up and jogged the balance of the fall. This is a good time to work on its feet and legs if they are the least bit sore or off in any way.

TURNING OVER TO A TRAINER.

If the owner thinks his colt will do for the futurities he should turn his candidate over to the 


\section{BREEDING THE TROTTER}

best driver of colts he can afford, if he has not already done so. Many fast colts have been spoiled by cheap trainers who were thought well of by their employers, because they were nice fellows and good dressers. After the experienced trainer gets the colt it is useless to advise as to its training. No person can lay down rules that will fit all cases and the writer does not intend to try the experiment.

\section{USE OF BANDAGES AND WASHES.}

Of course I have opinions on certain points in training colts, which apply to all cases. For instance, I am opposed to the constant use of bandages unless absolutely necessary. I do not believe in washes, unless just after a race. If the groom would spend as much time rubbing the legs as he does in applying liniments and lotions the horse would be much better off.

\section{PACKING OF FEET.}

I attach considerable importance to the proper packing of horse's feet and have obtained the best results from blue clay. If this be too expensive or hard to get use linseed meal and bran, proportions two-thirds meal to one-third bran, mixed with warm water. The very worst possible packing, but one now seldom used, is cow manure.

The programme as outlined in this chapter is the one used in developing all the Village Farm horses. Many of them afterwards became champions and raced and stayed sound for years. 


\section{BREEDING THE TROTTER}

\section{AGED HORSES.}

I will give no advice on the care of aged racehorses because that is a matter which should be left to the horse's trainer. Aged horses will be carried through the winter with jog work very much the same as two-year-olds and three-yearolds except that they should be jogged longer distances, say from four to seven miles, as mentioned in connection with stallions. Right here I might advise especial care being given a horse in its fouryear-old form. Very few horses are at their best then, perhaps partly because of shedding more teeth at that age than at any other time. One of the most important things in caring for a horse is to see that its teeth are well looked after. A competent man should examine all of your horses once a year, either in December or January.

The colt that was not thought fast enough to start in the futurities may, when it reaches five years, be fast enough to race in stakes or classes, in which event it may be expected to show considerable promise in its four-year-old form and should be given special preparation. This preparation, if correctly given, should leave the horse clean and sound. It will have had considerable fast work, even up to full miles, but it must not be trained to death, and should have a lot of fast miles left in it to use later on to get the money with.

It is significant that only a small proportion of the horses that have been trained with a view of giving them fast trials in the fall previous to their prospective Grand Circuit campaign have reached 


\section{BREEDING THE TROTTER}

the races. It would have been much better to have given them many miles a little slower so that they would have been well muscled up for the stiff preparation of the spring. Such a course lessens the number of cripples that have to be shipped home, much to the disgust of the owners, trainers and friends of both. No horse should be worked excessively during the winter. It keeps him keyed up too long. Remember, however, that long jogs, while they muscle up a horse, do not develop its speed; only brush work does that, so the proper combination of both is necessary.

While speaking of horse racing I might mention a fact that is not emphasized enough. Many horses are prepared for races in which it is not thought they can win, but in which it is expected they can easily win second or third money. As a matter of fact the second or third horses often have a harder time winning and have more of their vitality sapped than the winner. Usually the winner goes no faster than it is forced, whereas the horse finishing second has probably throughout the mile been struggling either to defeat the first horse or to withstand the rush of the third. Then, again, a horse that wins can often be saved a little at different points in the mile whereas the majority of the horses behind are constantly struggling to better their places.

Just a closing paragraph of advice to the owner of a horse in training. Never ask your trainer to show you as fast a mile with your horse as he can go. He may need that mile in a race sometime. 


\section{Chapter Eight}

\section{PREPARING FOR THE SALES AND THE SHOW RINGS}

Avoid Over-Production.-The Best Age at Which to Sell.Preparing for Sales.-Culls.-Show Horses.-Preparing for Shows.-Incidentals.

F course it is next to impossible for any breeder to retain every colt he raises. In time the largest farm will become over stocked. It is necessary, therefore, for the breeder to sell a certain number of colts each year. This may be done either by private sale or at public auction. Most will prefer the latter method because the market is already provided and each horse is sold for what the public, and not one man, thinks it is worth.

THE BEST AGE AT WHICH TO SELL.

It has already been mentioned that the best age at which to sell horses is either in the fall before they are two years old or in the spring after they become that age. This assertion is made after an extended experience in selling colts at all ages. The average two-year-old can be sold at a maxi- 


\section{BREEDING THE TROTTER}

mum price for a minimum expense. Colts at this age not only appeal to the professional horsernen, anxious to secure futurity prospects, but also to the amateurs who like to try their hands at developing speed, particularly young business men who wish to fuss around horses as a recreation after office hours.

\section{PREPARING FOR SALES.}

In conditioning colts for sales they cannot be too well broken. It somewhat enhances the value of a colt to be broken to double harness, but that is not difficult because a colt well broken to single harness will drive double.

The colt should be in the best possible physical condition.

I advise by all means to give the sale colt its preliminary exercise beside a lead pony, in which manner also it should be shown in the ring. The best-bred and best-looking colt in the world will not bring its full value in the auction ring if it cannot show a promise of speed commensurate with its breeding and individuality. A colt will show more speed in the sale ring beside a pony than in any other way.

When the colt is ready to be sold it should be shown by an experienced and competent man. A green colt and a green exhibitor make a bad combination which often results in a colt bringing only half its value. The sale ring is no place to curtail expenses. 


\section{BREEDING THE TROTTER}

CULLS.

Almost every farm has a few "culls." I would not advise sending them to a public auction. It hurts the sale business by lowering averages, and it hurts your farm's reputation, also the reputation of the blood lines you are propagating. Culls can usually be disposed of to advantage among the farmers of your neighborhood, who will use them as general-purpose horses.

\section{SHOW HORSES.}

Now, as to show horses, if you have followed out the advice as to combining beauty and speed you will have some show horses with which you should take pride in demonstrating your success to the world.

\section{PREPARING FOR SHOWS.}

The show horse should have still better attention than the sale horse. He should be thoroughly broken, with the best of manners in stable and ring, should be in the finest possible condition, in fact, be as near perfection as it is possible for you to make him. One of the important things to teach a show horse is, to stick to a pure gait at all times, regardless of short turns, bad footing and the excitement around the ringside.

Your horses should be shown by the best man that you can afford to engage. 


\section{BREEDING THE TROTTER}

INCIDENTALS.

Considerable attention should be paid to the fittings. Have the best of harness, leading rigs and good, competent grooms, all dressed alike in whatever colors you select.

I think all exhibitors in the show ring should be placed on an equal footing and all be made to show in one way. The best way to show a horse in the ring is beside a saddle pony. It gives the best satisfaction to exhibitor, association, judges and public.

Whatever you do, do not go to the show ring unprepared, for you will come away dissatisfied and will probably lay blame on the association and judges which you yourself should shoulder.

Take your medicine like a gentleman. Sooner or later you will win ribbons enough to make you forget all your troubles. 


\section{Chapter Nine}

\section{MANAGEMENT OF A STOCK FARM}

Business Principles.-The Superintendent.-The Trainer. -Grooms.-Sources of Revenue.-Advertising and Catalogues.-Breeding Records.-Causes of Failures.-Sources of Waste.

7 HIS chapter will be written for the benefit of the gentleman who has founded a stock farm of considerable size, although the advice and suggestions may be put to practice by him who breeds on a smaller scale.

I will suppose that the reader is the owner of a farm laid out as directed in chapter three. Considerable money, doubtless, has been spent on the establishment.

\section{BUSINESS PRINCIPLES.}

Even if it has been founded for pleasure alone, the farm should be conducted on business principles and, if possible, made to pay expenses. When one comes out before the trotting world as a breeder, he is entering a field which contains some of the smartest and shrewdest business men in the country. In fact, if some horsemen who follow the business professionally had devoted a like amount of attention to commercial pursuits they would have made fortunes for themselves. 


\section{BREEDING THE TROTTER}

THE SUPERINTENDENT.

If you have founded a large farm or are about to do so, the first thing for you to do is to secure your superintendent. He will be hard to select, although, when it becomes known that you intend embarking in the breeding business, you will hear from many who on their own letter paper look to be entirely competent.

The superintendent should be competent to take full charge of the property and be the sole manager thereof, except that he should be expected to report to the proprietor once or twice a week and be guided in important details by the latter's suggestions.

Right here a word to superintendents: Do not make a great, long, tiresome report to the proprietor, but condense things so that the details will not bother him. At the same time, nothing of importance should ever be kept from him.

The superintendent should have a thorough and practical knowledge of all details pertaining to the raising of stock and be able to handle things in a business-like manner. Among other details, the superintendent will be expected to oversee the breeding of mares, assisting mares to foal, breaking and training colts, and developing speed. He should also have a practical knowledge of farming in order to know that the department which should be in charge of a head fa is running properly. The "kid-gloved" super- 


\section{BREEDING THE TROTTER}

intendent, or the one continually running to town, will not prove very successful on a large stock farm.

The superintendent, in addition to understanding about the breeding of mares, should know how to keep breeding records, forms of which were given in chapter four.

The superintendent should make a thorough inspection of the farm once a day, twice is better, and see that everything is being done right and that every animal is properly cared for and watered and fed regularly.

The superintendent should be the handiest allaround man on the farm and he who is the most saccessful will be the first up in the morning and the last to leave the stables at night.

A thorough knowledge of brood-mares is indispensable to the superintendent, especially when a mare needs assistance in foaling hours before a veterinarian can arrive. Some large farms have a veterinarian in their employ, but if the superintendent is of the right sort this large item of expense may be cancelled.

The superintendent should understand enough about the development of speed to be able to break and train colts till they are old enough to be turned over to a trainer. Every colt, if carefully handled, will be turned over to the trainer, sound, clean-limbed and otherwise uninjured.

The superintendent's duties, while arduous, offer the interested man much satisfaction in viewing the results of his handiwork. 


\section{BREEDING THE TROTTER}

It is hardly necessary to say I do not think any superintendent can run a farm by sitting in the parlor of his house or in his farm office, or in running about the country.

The superintendent's first duty on taking charge of a stock farm is to see that he has as efficient a corps of workers under him as it is possible for him to secure, according to local conditions.

It will be unnecessary to outline in detail the duties of a superintendent. A competent man will understand that for himself, and it is to be supposed that the owner has chosen an ideal man for the ideal farm outlined.

I might mention here that the owner need not be surprised to receive letters from the employees at the farm, "knocking" the busy superintendent. That seems to be a favorite method with incompetent men whom the superintendent has to chastise. If such men fear to write the proprietor they will try to reach his ear while on a visit to the farm and will unwind a long yarn in regard to a supposed mismanagement of the farm. Such things will naturally cause the owner to worry and he will wonder whether or not he has the right man in the right place. He will find, in most cases, the "knockers" are dissatisfied employees. The majority of farm proprietors are business men enough to be able to tell if the farm is being rightly managed, without consulting the grooms.

A farm about which everything is kept neat, 


\section{BREEDING THE TROTTER}

clean and tidy is usually a well-managed one. It does not need an expert to decide whether the stock is in good shape, whether the colts are acting right or whether they are being properly trained and developed.

The monthly statement will show whether or not the superintendent is trying to make a business success of the venture.

The superintendent should be held responsible for the details of breaking and developing the colts and when fall comes he and the colt trainers should be able to turn some promising material over to the speed department, without resorting to excuses.

The competent superintendent does not need to use such excuses as, "the track wasn't good," " there was a great deal of rainy weather," "your family of horses is not the right kind to produce speed," etc.

As before mentioned, the superintendent should at all times consult the proprietor and take pleasure in showing him all the stock at all times, keeping nothing away from him.

The proprietor should, in return, if he has selected the right man, never hesitate to seek advice from his superintendent, rather than from the many outsiders, some of them personal friends, always willing to offer it. The proprietor should at all times evince an interest in his stock. It is not very encouraging for a superintendent and other employees to work on a farm where their efforts do not interest the proprietor. 
The bank account should be jealously guarded by the superintendent, who should make every effort to show that he is interested in keeping expenses down without being penurious. There is such a thing as being too economical on a farm which is expected to turn out a great stable of successful race-horses to help pay the running expenses of the farm.

Never be afraid to pay a competent man, be he superintendent, trainer, colt-breeder or groom, a good fair salary. Such a man is cheaper to the proprietor than an incompetent man who will work for little or nothing.

\section{THE TRAINER.}

When the training department outgrows the superintendent, it will be necessary to place it in charge of a trainer, the selection of which is an important step, particularly since the reputation of the farm depends on him to a considerable degree.

In this connection I am going to quote portions of a letter of advice I once wrote a trainer. It explains itself.

"Your kind letter received and at your request I will give you my views. Yes, I fully agree with you that your colts have done remarkably well in their work, a great deal better than I expected, but that is one of the reasons you should be careful. . . . I have a deep interest in you and am anxious to see you at the top of the ladder. You have mastered the profession in training young 


\section{BREEDING THE TROTTER}

horses. In my mind you are one of the best developers of speed that there is in this country. . . . I think you may be hurrying the preparation and making too much speed in a short time.

Now, my boy, above all things, keep them sound. Look them over every morning after you have worked them and if you see the least little thing, I should certainly stop and go a little slower. . . . You have as good material, in my opinion, as there is in this country or any other country. You have everything to work with, or if not, you had better get it. You have your own help and if you have not good help you had better get it. . . . I wish to call your attention to the fact that the Farm now hinges on you. You will either go down as not smart enough to develop and get a stable of horses ready for the Grand Circuit or you will be on the top of the heap in - . . . If you accomplish what I have mapped out in my mind, you will be one of the most prominent trainers in America, and the Farm will be one of the most prominent stock farms in the country. If you fail I need not tell you the rest. There are more reporters anxious to write about failures, free of expense, than there are to write a boost, unless paid for it. Now, all you have to do is-plan far enough ahead and work early and late to accomplish your ends."

After engaging a trainer, which will probably be on a one, two, three, or five year contract, salary payable monthly, it is up to the proprietor to 


\section{BREEDING THE TROTTER}

give the trainer every opportunity to develop the speed of his colts. See that he is amply provided with sulkies, carts, harness, boots and other equipment.

\section{GROOMS.}

Good grooms are a necessity on a farm and their worth is now recognized more than ever, for they are receiving larger salaries to-day than ever before, to my knowledge. Grooms deserve a great deal of credit. They have a pretty hard life and some receive small pay for the responsibility resting upon them. Many business men who would not trust their clerks to carry ten thousand dollars unless guarded by a detective will place a ten thousand dollar horse in charge of an incompetent man because he is cheap.

The groom should take pride enough in himself and the impression the farm makes on visitors to appear as neat as possible about the stables. He should never leave his horses when they need attention. He should no more think of running to town to a saloon or playing cards or shooting dice than would the cashier of a bank. If a groom takes no pride in appearance on the farm, he should at least do so on the race-track. Nothing gives a stable of horses on a race-track a cleaner appearance than well-dressed, gentlemanly-looking grooms. Every man on a stock farm should be up at five o'clock in order to have the morning feeding completed by breakfast time, after which the work of the day will require the attention of all. 


\section{BREEDING THE TROTTER}

\section{SOURCES OF REVENUE.}

The two chief sources of revenue on a stock farm are the racing stable and the stallions. The success of the former depends on so many contingencies that the latter generally prove the surest means of income.

Unless the stallions are being reserved for private use, it will be the superintendent's duty to use every effort to attract public patronage to them.

\section{ADVERTISING AND CATALOGUES.}

If your stallions are worth advertising at all they are worth advertising well, and space should be contracted for in the principal turf papers. It is generally advisable to issue yearly catalogues of your stock to mail to prospective patrons and purchasers. A tastily arranged catalogue, statistically correct, is a great advertisement for a stock farm and will receive the support of the turf press because it makes it easy for the writers to look up the breeding of your stock when occasion requires.

BREEDING RECORDS.

To make the breeding department a success it is imperative that the records be properly kept and in such a manner that, in case the superintendent is absent through illness, any other competent man may refer to the records and run things till the superintendent's return. Blank forms for a trial sheet, breeding certificates, etc., were given in chapter four. 


\section{BREEDING THE TROTTER}

System is as necessary on a stock farm as in an office or a bank, perhaps more so.

\section{CAUSES OF FAILURES.}

If the proprietor has selected the right stock and has employed the right trainer, he will in a few years be listed with the prominent farms of the country. If not, he had better sell out and start over again, rather than continue with a failure.

If you need any excuse for selling, one of the following well-worn ones may do: "My health is not good. I must give up my farm." " I contemplate taking a trip to Europe." "My business is such I cannot afford to give up so much time to the details of a stock farm," etc.

Stock-farm failures are generally due to extravagant methods, or a failure to select the right stallion or the right brood-mares.

\section{SOURCES OF WASTE.}

Among the sources of waste on a stock farm are feed and bedding. These items are especially large in the stable at the races and the trainer should economize whenever possible.

Feed for the farm should be purchased in large quantities at a time of year when markets are lowest. On large farms where not enough oats are raised to supply stock, it should be bought by carloads; bran the same way; other food stuff in proportion.

Bedding runs into money very quickly and 


\section{BREEDING THE TROTTER}

grooms should be instructed to avoid waste. It should be well shaken up after removing from the stalls and when dried may be used again. The balance will be deposited in the manure pile. Manure piles should be kept tidy and some distance from the barn. Every day or two, or at least not longer than once a week, the manure should be carted to the fields.

After the bedding has been removed from the stalls, they should be swept up clean and well aired beside being disinfected with some good disinfectant. My choice is slaked lime, next choice Sanitas. Such treatment will keep the stalls in sanitary condition, will kill the ammonia and make the barn smell sweet. The stalls should be disinfected once a week, and in the spring and fall, if weather is damp, twice a week, or oftener if necessary. 


\section{Chapter Ten}

\section{CARE OF THE FEET AND TEETH}

Care of Feet.- Young Colts.-Corns.-The Perfect Hoof.Ring-Bone.-After the Races.-Thrush.-Care of the Teeth.

$\sim \mathrm{WO}$ of the important details in connection with the management of a stock farm are the care of the horse's feet and teeth. The subject is so important in my estimation, that it is worthy of a separate chapter.

The old remark, "No foot, no horse," is a very true one and applies to every horse on the farm.

\section{CARE OF FEET.}

The stallion should be shod every thirty days in order to keep his feet level and the heels wide enough to prevent contraction.

The brood-mares should be gone over carefully every April and their feet trimmed, leveled and rounded up. This should be done again in August and in December.

The feet of the colts and horses in training should be regularly cared for as necessity demands.

YOUNG COLTS.

If the feet of young colts are not properly looked after it will be found that in ninety-eight per cent of them the inside quarters of the front feet are narrower than the outside; and in ninety 


\section{BREEDING THE TROTTER}

per cent the outside quarters of the hind feet will be narrower than the inside. I think the reason for this is because of the position young foals take in sucking, which retards the circulation of the blood on the inside of the front feet and on the outside of the hind feet.

The foal's feet should be leveled when it is from ten to fifteen days old. The hoof will be soft and tender and may be trimmed with a jackknife. This treatment should be continued till the colt is about four months old, when the inside and outside quarters should be of the same width. This will prevent corns.

CORNS.

It is a mistaken idea that unshod colts never have corns. I have often seen them with corns and with contracted heels.

Imperfect feet are often a peculiarity of certain families. Some families are predisposed to high heels, others to low.

If the feet of the colts received closer attention we would have fewer knee-knockers and horses that toe out or toe in. I would rather have one colt that toes in than ten that toe out. Personally, I have very little use for horses that toe out and would not select for a matron a mare that toed out, no matter how well bred she might be.

THE PERFECT HOOF.

The front of a colt's hoof should stand at an angle of forty-five degrees to the ground, or if not, 


\section{BREEDING THE TROTTER}

the hoof should be so trimmed or shod that it will have that angle.

$$
\text { RING-BONE. }
$$

I might say here that ring-bone in colts is very often caused by keeping them standing in stalls heavily bedded. The colt's ankles are tender and the continual walking around in the deep straw causes the disorder.

\section{AFTER THE RACES}

If you have a training stable, after the horses return from the races in the fall a competent blacksmith should go over the campaigners. If there are any signs of contracted heels, the horse should be shod with springs. A cut of a spring

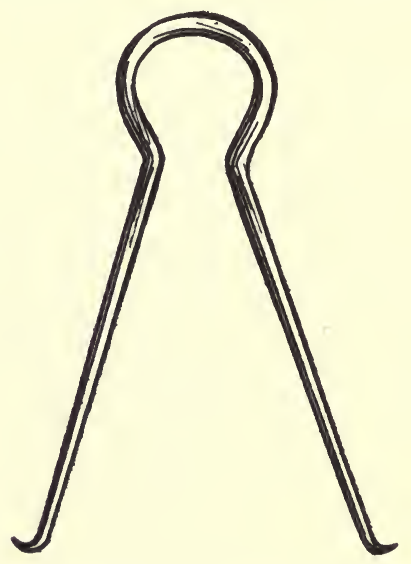

now in common use is presented herewith. The first pair was made and used at Village Farm. 


\section{BREEDING THE TROTTER}

\section{THRUSH.}

Thrush is caused by not cleaning a horse's feet properly. A colt's feet, if not cleaned daily, should at least be attended to three times a week. The brood-mare's feet should be cleaned at least once a week, twice is better.

If thrush is not cured, it will eat away the frog and the animal will probably go sore and lame, while the heels will contract.

The quickest and surest way to cure thrush is to trim away the diseased portions of the foot and pour into each side of the frog and into the center of the foot a small quantity of what is commonly called butter of antimony. One application will cure. Powdered calomel is good, but has to be applied several times.

Remember that thrush is caused by neglect and will never bother stock properly cared for.

\section{CARE OF TEETH}

Equally important as the care of the feet is the care of the teeth. A colt's teeth should be first floated with a fine file, when the colt is from five to eight months old.

When the teeth are shedding if the caps do not come off I would assist nature by using forceps, or you may call your veterinarian. Also watcl the colts when their molars are shedding, as it sometimes leaves them in bad condition, indicated by tucked-up flanks and a ruffled coat.

From the time a horse is four years old its teeth 


\section{BREEDING THE TROTTER}

should be dressed by a competent man every year. I prefer to have this done in November or in December.

All horses on the farm should be attended to. It will keep them in better health and cause them to live longer.

An important time to examine a colt's teeth is just before he is to be broken to harness. Often uneven teeth cause the colt to carry its head sideways, or they will cut its cheek and make the colt nervous and irritable. 


\section{Chapter Eleven}

\section{SOME AILMENTS AND DISORDERS}

Treatment of Barren Mares. - Sweat-box. Treatment for Pneumonia. - Distemper. - When Stallions are Dull. - Masturbation. - Navel Trouble. - Diarrhea.

TUST a word of introduction to the final chapter, wherein I will mention my methods of treating certain sicknesses, disorders, etc. I will make no attempt to write a chapter on "Every Horseman His Own Doctor," but will merely record my methods of treatment (some original) in certain cases where I have had good success.

TREATMENT OF BARREN MARES.

My treatment of barren mares has been extensive and successful, and while on Village Farm a large number of mares were shipped to me for treatment from all parts of the country.

One of my "star" cases was Lady Bunker, the dam of Guy Wilkes (2.151/4). She had been barren for seven years and had been treated by competent veterinarians in Kentucky before being shipped to me. After undergoing my treatment she was gotten in foal at the first service, and produced three foals, one of them being Welcome Bunker, the dam of Cheery Lass (2.033/4) and King Direct (2.05\%/4). Another "star" case was 


\section{BREEDING THE TROTTER}

Gleam, the dam of Rex Americus (2.1 I I $/ 4$ ). She had not produced for two years and had been given up as barren, but succumbed to first treatment.

My first step in treating a barren mare is to get her in the best possible physical condition. In order to purify the blood I give a tonic three times a day, for from two to three weeks before commencing treatment.

Mares are usually barren for two reasons: (I) because of contracted womb, the mouth of which is often nearly closed, and (2) because of leucorrhea, or what is commonly called " whites," when the womb is in a loose, flabby condition. The latter condition is hardest to treat in order to get the mare in proper condition to breed.

To determine the condition of the womb, a speculum should be used. If some one experienced in the use of the same is not at hand, the assistance of a veterinarian should be sought.

If, on examination, you find the womb closed, insert an Eureka Pregnator into the mouth of the womb, leaving it there for from twenty-four to thirty-six hours. After removing it, wash out the mare with warm distilled water, to every three pints of which one ounce of creoline has been thoroughly mixed. Breed the mare at once.

In case the womb is discovered to be loose and flabby, wait till the mare comes in season and wash out the womb in the morning with warm distilled water, to every two quarts of which has been added one drachm of sulphate of zinc. In 


\section{BREEDING THE TROTTER}

the evening wash out the womb with two quarts of water to which has been added two tablespoonfuls of a solution of permanganate-potash. Use a force pump with the wash. Continue this washing every day while the mare is in season. Then let her run eighteen or twenty-one days. When in season again, continue the washing. When she comes in season the third time examine the womb and if it is apparently in perfect condition breed the mare. If not, continue the washing till it is. I have never failed in following this method.

SWEAT-BOX TREATMENT FOR PNEUMONIA.

As a rule the first symptoms of pneumonia and pleurisy are a chill, after which the temperature (which at normal is between ninety-nine degrees and one hundred degrees) runs up to one hundred and two degrees or higher. Sometimes there is a short cough. The animal is dull, the skin is hot but the legs remain cold. Usually the animal is in such pain it grunts when turning around in the stall, or when one presses against its side back of the forearm.

If the case is taken in hand just as soon as the chill is noticed and tincture of aconite be given according to directions, the disease may be warded off. But if it progresses and fever sets in put the horse into a sweat-box.

There should be one of these on every stock farm. The sweat-box is a stall sixteen by twenty feet, and eight feet high, double sealed with tar paper, made perfectly tight. There should be a 


\section{BREEDING THE TROTTER}

ventilator in the center of the ceiling to regulate the temperature and two windows on each side of the stall which may be let down from the top. In one corner of the stall, with a heavy bar around it, place a large heavy stove, which will burn hard wood or soft coal. The floor on which the stove sits and the walls about it should be covered with zinc.

When a horse is taken with pneumonia start the sweat-box fire and run the temperature of the room up to one hundred and twenty degrees or one hundred and thirty degrees, or even one hundred and forty degrees. Lead the horse in and tie it up. Have an attendant to care for the horse and keep the fire going. The average man will not be able to remain with the horse all the time it is in the sweat-box, and it will usually be necessary to have two attendants, who will relieve each other every fifteen minutes or half an hour.

Give the horse all the cold water it will drink. In the course of half an hour the horse will commence to sweat. Wait till the sweat begins to run down his legs and drop on the floor and then scrape the horse as you would a trotter that has just finished a stiff mile on a warm summer's day. After this, open the ventilator so that the warm air will escape gradually. Let the fire die down. The attendants should rub the horse down and do him up as they would a race-horse. This treatment will take from two and one-half to three hours, when the temperature of the room should be down to about fifty-five degrees or sixty degrees. 
When the horse is ready to blanket, and before doing so, take some lung salve or antiphlogistine and apply it on each side of the horse over the lungs, or just back of the forearms. Rub the salve in thoroughly and then smooth the hair down. Also rub some of the salve around the horse's throat. After this blanket the horse. Put a good woolen sweat blanket next to the body and a body blanket and hood over this, then take the animal to a stall in which the temperature is around fifty degrees or fifty-five degrees. See that this stall is well ventilated, but without drafts, and that the horse has plenty of fresh air to breathe. Give it all the fresh cold water it will drink.

From now on give twenty drops of tincture of aconite root every four hours, according to directions, until the fever goes down, but never continue it beyond six doses and give it no oftener than once in four hours.

I have never had a case of pneumonia, taken in time, that was not cured with this treatment. In one case the horse's fever went to one hundred and seven degrees, although one hundred and four degrees is usually considered dangerous. Usually in forty-eight hours the horse's temperature will be normal, and the animal ready for use, but care should be exercised for a week or two to see that the horse is not subjected to sudden changes in temperature.

\section{DISTEMPER.}

All young horses are subject to distemper sometime during their lives, but generally between one 


\section{BREEDING THE TROTTER}

and three years of age. Distemper often breaks out in the fall of the year when the colts are running out cold nights or during rainy weather. Many colts get the disease in the spring. A horse has distemper but once in a lifetime.

The most positive first symptom of the disease, outside of a general depression, is the swelling of the glands under the jaw. This takes the form of a kernel, or tumor, which is very sensitive to the touch.

If the colts are running out take them in immediately and confine them in separate stalls as the disease is contagious. Place the sick colt in an isolated stall. Try to head off the disease, and thoroughly anoint the swollen parts with the following ointment, clipping the hair away, if necessary: lard, two pounds; tobacco, one-quarter of a pound; spirits of turpentine, one-quarter of a pint; tincture lobelia, two ounces; camphor, two ounces. After mixing the ointment place it on a slow fire and let it simmer a while. Stir it constantly. After the ointment is thoroughly mixed take it off the fire and stir till cold.

As a rule the colt's temperature will run up to from one hundred and two degrees to one hundred and four degrees. If you cannot head off the disease and the swelling increases prepare a flax-seed poultice about as hot as you can mix with bare hands and apply to under jaw with an eight-tailed bandage, as shown in cut. Change the poultice every two or three hours. When the pus of the swelling comes to a head, it will probably break 


\section{BREEDING THE TROTTER}

of its own accord. If not, use a lance to open the swelling and let pus out.

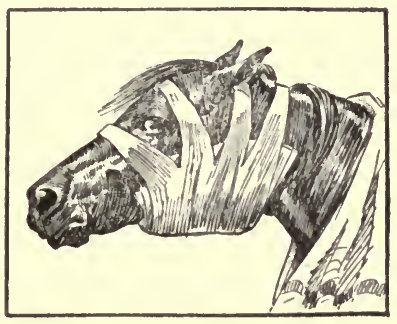

After this get the colt in good condition. During the disease and convalescence, the use of Stock Food will be found strengthening and beneficial, acting as a tonic.

Speaking of Stock Food, I wish to state that I have fed a great deal of it to horses of all ages and find it beneficial in aiding the digestion and assimilation of food and in strengthening the entire system. It gives horses brighter coats and better appetites. It makes brood-mares and stallions surer foal-getters and, in my opinion, will cause them to produce stronger foals.

WHEN STALLIONS ARE DULL.

When stallions are dull and not very anxious to cover mares, give them shorter, quicker jog work and a drachm of nux vomica and a drachm of iron, separately, once or twice a day.

\section{MASTURBATION.}

When stallions masturbate or abuse themselves give them one or two drachms of gum camphor every day. 


\section{BREEDING THE TROTTER}

NAVEL TROUBLE.

If a foal has navel trouble, lay it on its side, with two helpers to hold its head and hind legs. Take a catheter, with bulb syringe attachment, and pass it up the navel cord, injecting a solution of one-quarter ounce of creoline and two ounces of warm sterilized water. The navel channel divides, one channel running to each kidney. Insert the catheter as far as you can make an opening without forcing. Make an injection in each channel. The injection will prove healing and soothing and should be continued till the navel is healed up and closed. After making the first injection the colt should be given a half teaspoonful of sulphite (not sulphate) of soda in a little water from a rubber bottle, first four or five days till a cure is effected.

During this trouble pus is liable to form around the knees or hock or even abdomen. I do not advise lancing. Nature will remove the foreign matter.

\section{DIARRHEA.}

The blackberry cordial previously mentioned for diarrhea is made as follows:

Take one-half bushel of fresh blackberry roots, washed clean and cut up in sticks about four inches long; to this add one-quarter pound of cinnamon, one-quarter pound of cloves, onequarter pound of allspice. These spices must be whole. Put on to boil in either granite or porcelain kettles, with enough water to just cover the contents. Boil for two hours, then strain and 


\section{BREEDING THE TROTTER}

add five pounds of loaf sugar and boil to a syrup. Then add one quart of the best brandy. Bottle up in jugs or bottles. I prefer quart bottles. This should make one and one-half gallons.

The dose for colts from three days to a week old is one-half ounce three times a day, or oftener if necessary. This treatment should stop the trouble in from one to two days. Colts older than a month should have double the above dose.

I might mention that this remedy is very efficient for humans, the dose for children from six months to a year being from twenty-five drops to half a teaspoonful every three hours until relieved, then stretch the doses farther apart till well. 



\section{ALPHABETICAL INDEX}

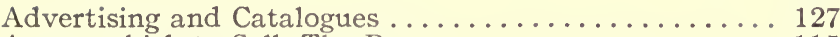

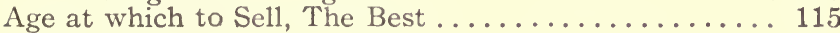

Ailments and Disorders, Some................ 135

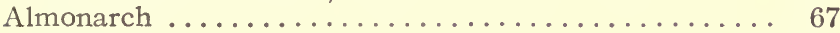

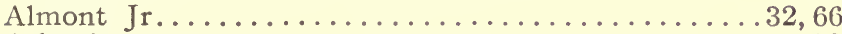

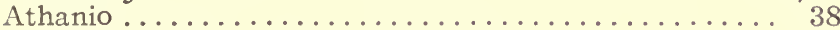

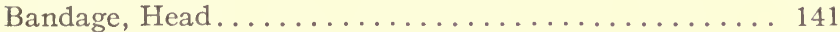

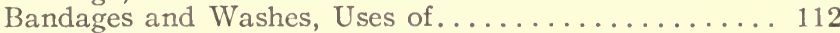

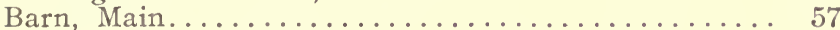

Barn, Plan of First Floor................ 60

Barn, Plan of Front Elevation.............. 59

Barn, Plan of One-Half Cross Section............ 61

Barn, Plan of Side Elevation............... 61

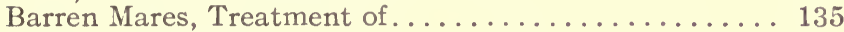

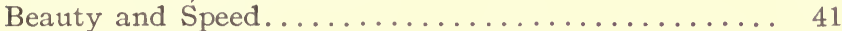

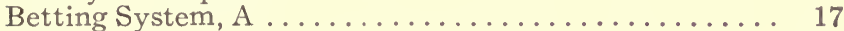

Blood Lines. . . . . . . . . . . . . . . . . . . . . . . . . 69

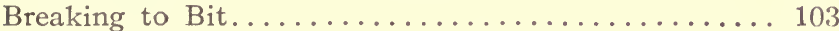

Breeding Pen.................. 78, 79, 81

Breeding Records........................ 127

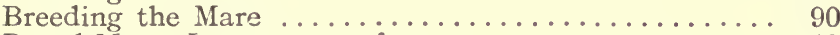

Brood-Mare, Importance of................ 40

Brood-Mare, My First.................... 3

Brood-Mares, Selecting................... 45

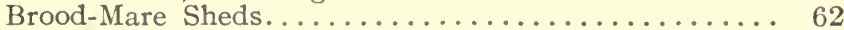

Brood-Mare, The........................ 83

Brood-Mare, Care of. ................. 85, 86

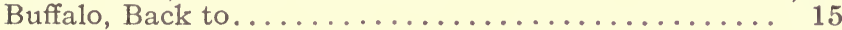

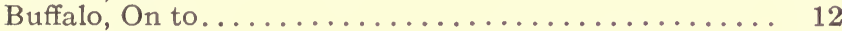

Business Principles. . . . . . . . . . . . . . . . . . . . 119

Cart, Hooking to........................ 105

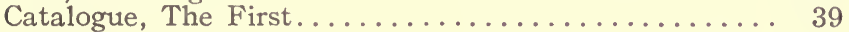

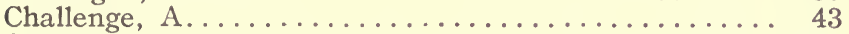

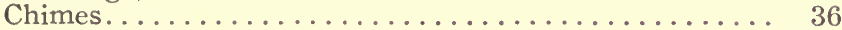

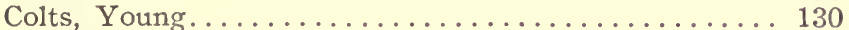

Concrete Examples-Almont Jr. .............. 66

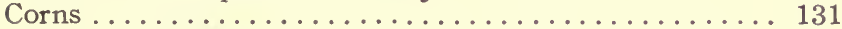

Covering the Mare......................... 78

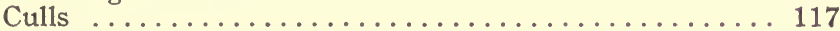

"Derricked" .......................... 13

Developed Mares, Age at which to Breed........... 94

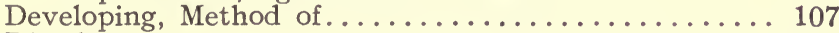

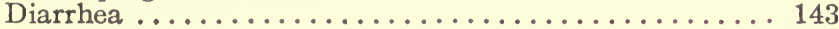




\section{ALPHABETICAL INDEX}

Page

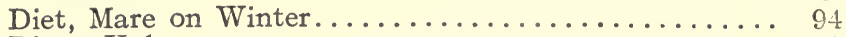

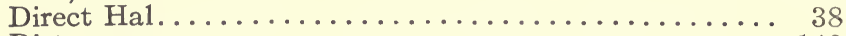

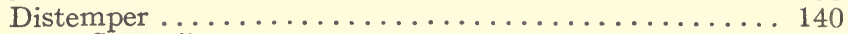

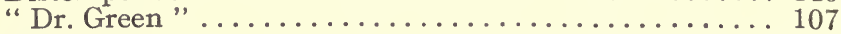

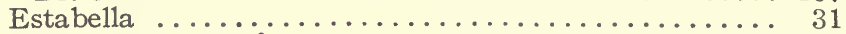

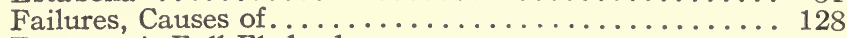

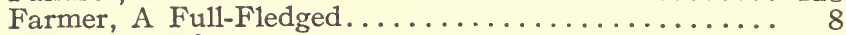

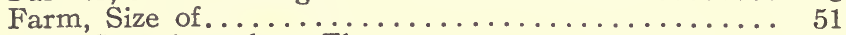

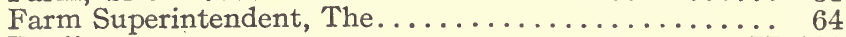

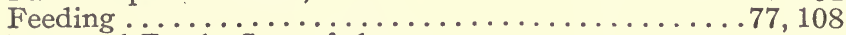

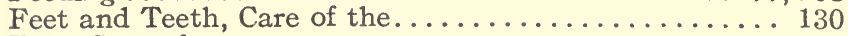

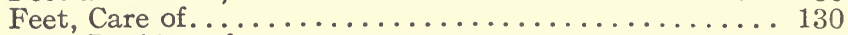

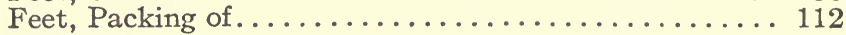

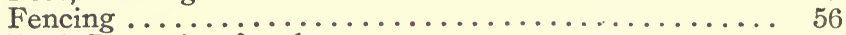

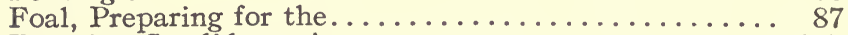

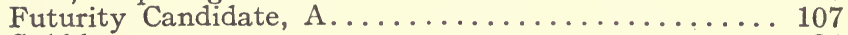

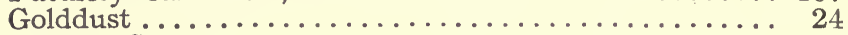

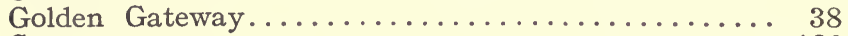

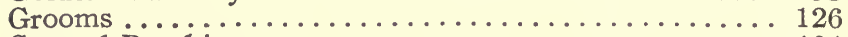

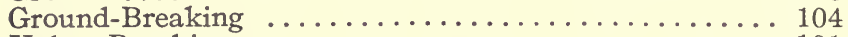

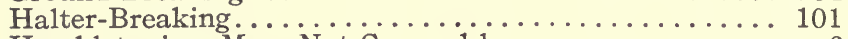

Hambletonian, Mare Not Covered by ............. 6

Hamlin, Mr., First Mare of.................. 23

Hamlin, Mr., First Team of................. 24

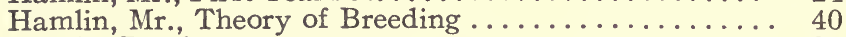

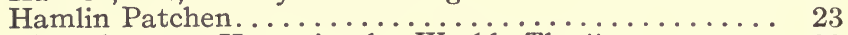

"Handsomest Horse in the World, The" ......... 33

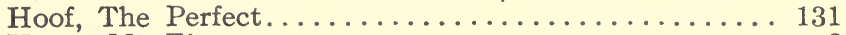

Horse, My First........................ 2

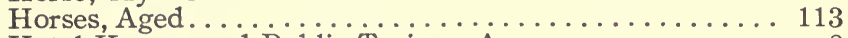

Hotel Keeper and Public Trainer, A............. 9

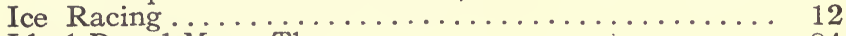

Ideal Brood-Mare, The.................... 84

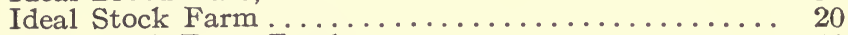

Ideal Stock Farm Track ................... 54

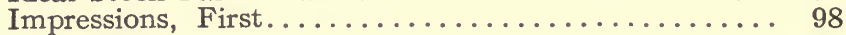

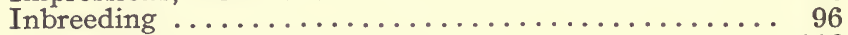

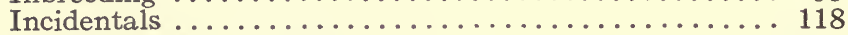

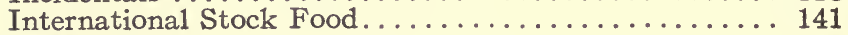

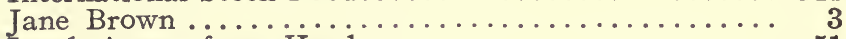

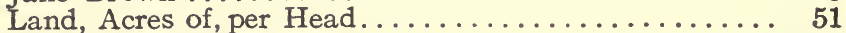

Lead Pony, Beside the.................... 103

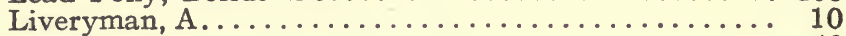

Location .......................... 49

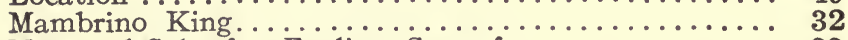

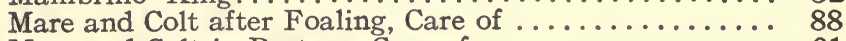

Mare and Colt in Pasture, Care of............... 91

Mares, Best Way to Purchase................ 83 


\section{ALPHABETICAL INDEX}

Page

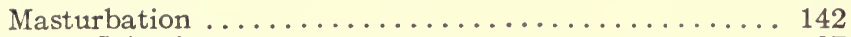

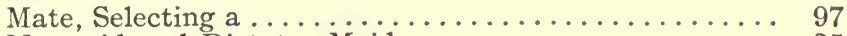

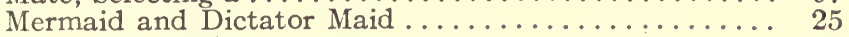

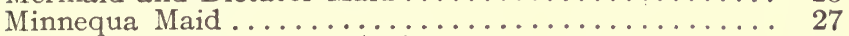

Muscles and Speed, Developing ................. 106

Natural Speed, Importance of . . . . . . . . . . . . . . 99

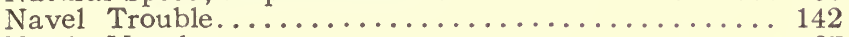

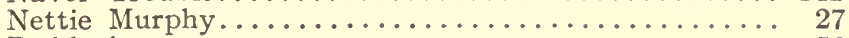

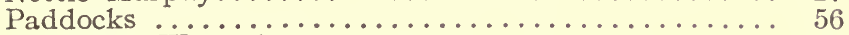

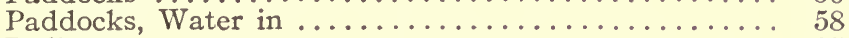

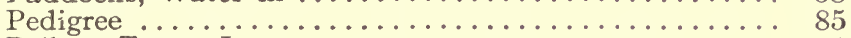

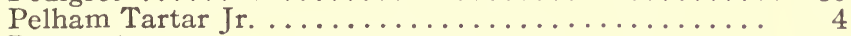

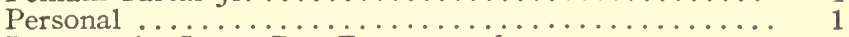

Pneumonia, Sweat-Box Treatment for. . . . . . . . . . . 137

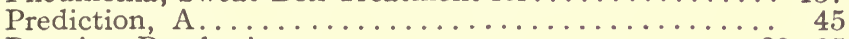

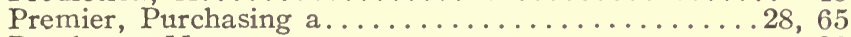

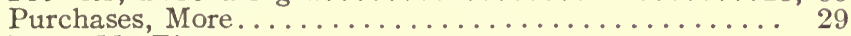

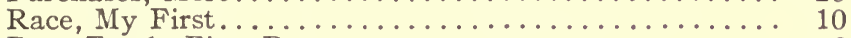

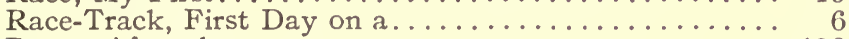

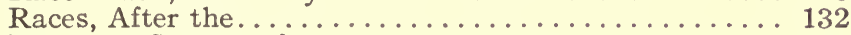

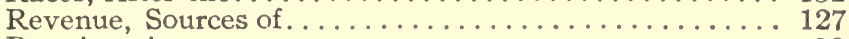

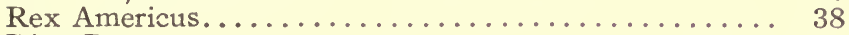

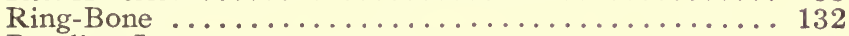

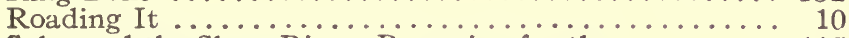

Sales and the Show Rings, Preparing for the......... 115

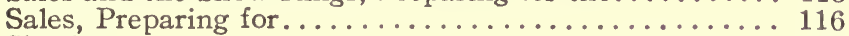

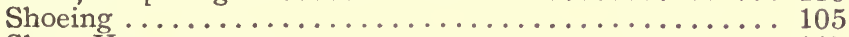

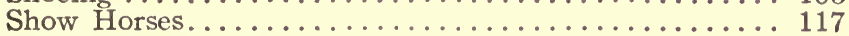

Shows, Preparing for. . . . . . . . . . . . . . . . 117

Sires, Developed.......................... 42

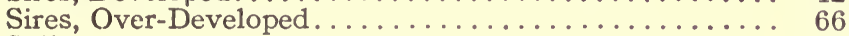

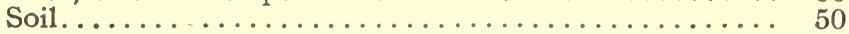

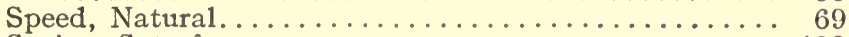

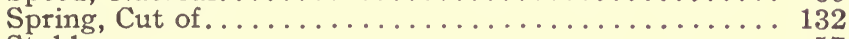

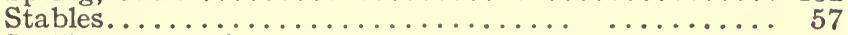

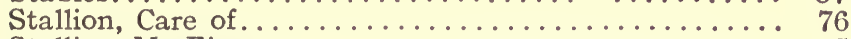

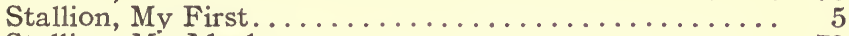

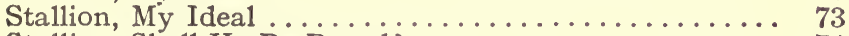

Stallion, Shall He Be Raced .................. 74

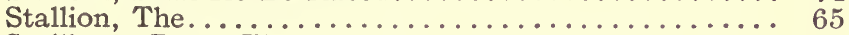

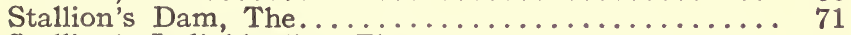

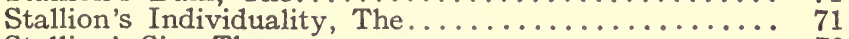

Stallion's Sire, The....................... 70

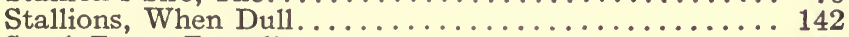

Stock Farm, Founding a.................... 49

Stock Farm, Management of a................ 119

Stud Book, Ideal Form of. . . . . . . . . . . . . 81, 82

Stud Season, The............................... 75 


\section{ALPHABETICAL INDEX}

Page

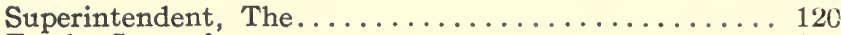

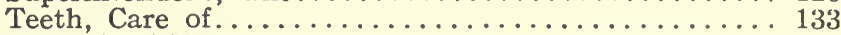

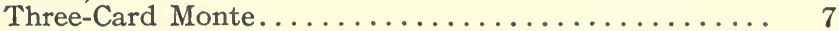

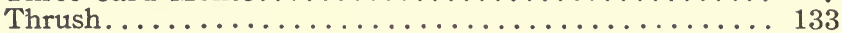

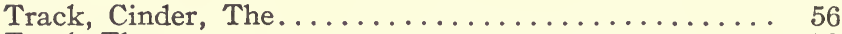

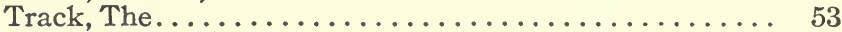

Tracks, Rules for Laying Out................ 53

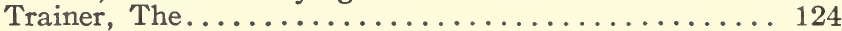

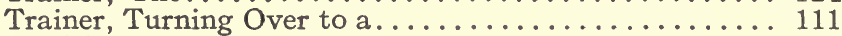

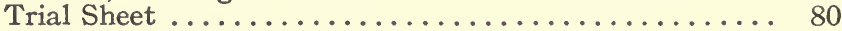

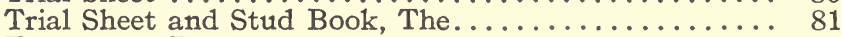

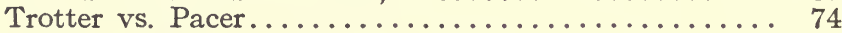

Trotting Nursery, World's Greatest.............. 21

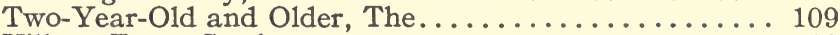

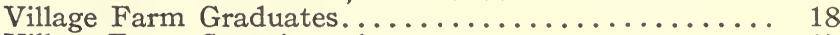

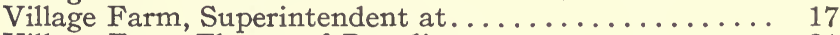

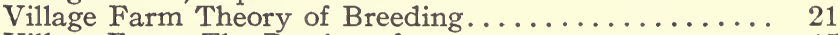

Village Farm, The Passing of ................ 45

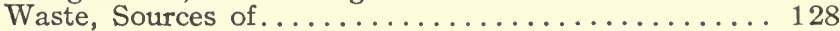

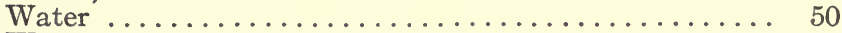

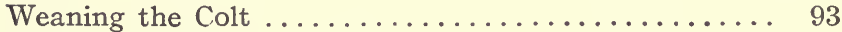

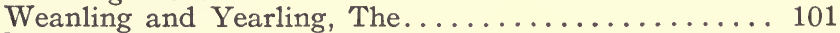

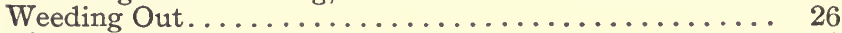

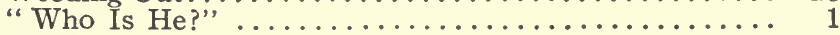

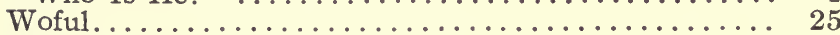

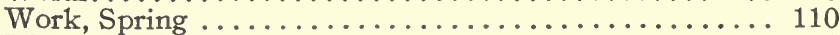

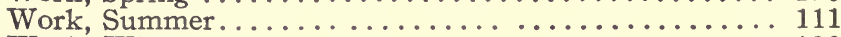

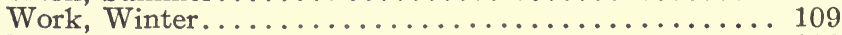

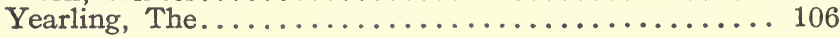

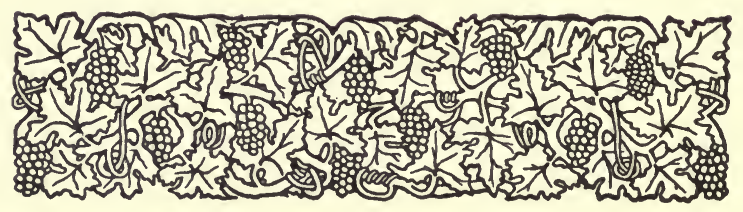





\section{THE AMERICAN TROTTER}

\section{By S. W. PARLIN}

Editor of American Horse Breeder

A volume of 320 pages treating of the origin, history and development of the trotter and pacer, with full page engravings of notable horses, past and present.

"A book that should be in the hands of every brood-mare owner."

-John Bradburn

\section{PRICE TWO DOLLARS}

Sent, postage paid, to any address in the United States or Canada.

\section{AMERICAN HORSE BREEDER} i6i High Street, Boston, Mass. 


\section{HORSE - HEALTH}

Is a dependable remedy of the highest quality for correcting disorders of the $\mathrm{Di}$ gestive, Kidney and Blood Organs. It expels stomach worms without the usual violent action of vermifuges. For the colt that does not thrive well, Horse-Health is guaranteed to give absolute satisfaction.

\begin{tabular}{|c|c|}
\hline & $\begin{array}{l}\text { MRSE } \\
\text { EALTH }\end{array}$ \\
\hline $\begin{array}{l}\text { experienced } \\
\text { successful } \\
\text { horsemen }\end{array}$ & $\begin{array}{l}\text { HORSE } \\
\text { EALTH }\end{array}$ \\
\hline $\begin{array}{l}\text { in treating } \\
\text { many of }\end{array}$ & $\begin{array}{l}\text { MORSE } \\
\text { ELTH }\end{array}$ \\
\hline $\begin{array}{l}\text { the world's } \\
\text { most }\end{array}$ & $\begin{array}{l}\text { MORSE } \\
\text { IEALTH }\end{array}$ \\
\hline valuable & HORSE \\
\hline colts and & IEALTH \\
\hline $\begin{array}{c}\text { aged } \\
\text { horses }\end{array}$ & $\begin{array}{l}\text { HORSE } \\
\text { EALTH }\end{array}$ \\
\hline
\end{tabular}

\section{Used \\ by \\ most \\ every \\ Breeding \\ Farm

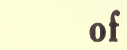

prominence

in the

United

States

Horse-Health contains absolutely no poisonous, re-active drugs and is adapted for treating either colts or aged horses.

Sold in two size boxes, $1 / 2-$ lb. 50c, 7-lb. $\$ 5.00$

Sent prepaid to all parts of the United States by

Horse-Health Co. :: Norwalk, Conn. 390 Main Avenue 


\section{THE AMERICAN HORSE BREEDER}

The newsiest, best illustrated, ablest edited horse paper published.

\section{SUBSCRIPTION PRICE}

$\$ 2.00$ per year in advance, $\$ \mathbf{\$ 1 . 0 0}$ for six months. $\$ 3.00$ per year, $\$ 1.50$ for six months, to Canada.

\section{SAMPLE COPIES}

Sent on application. Address

\section{AMERICAN HORSE BREEDER i6i High Street, Boston, Mass.}




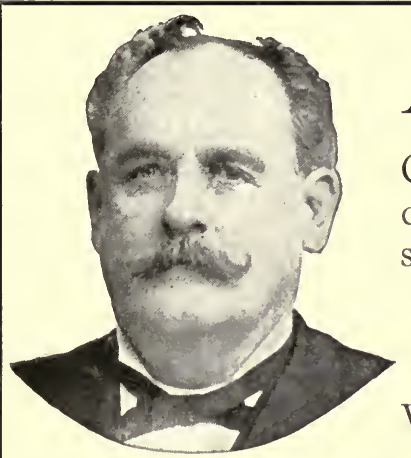

\section{Any Horse}

Can be improved in condition, health and spirits if given

\section{Dr. A. C. Daniels' Renovator Powders}

Vim, Strength, Health

The horse going sore forward in one heat can make good in the next two if his feet have Dr. Daniels' Liniment and hot water - it's a wonder.

Worms in the horse are bad, both for the owner and the horse.

Daniels' Worm Killer fixes the worms.

Dr. Daniels' Colic Drops has cured Horse Colic for Thirty Years.

It's a sure thing - warranted.

Daniels' Distemper Remedy. The lifesaver from colds, coughs, fever, distemper and lung troubles.

These famous remedies can be had in almost any country on earth and most any drug store in any town.

Information DR. A. C. DANIELS, Inc. I72 Milk Street, Boston, Mass. 






\section{DAY USE}

RETURN TO DESK FROM WHICH BORROWED

的

\section{CIRCULATION DEPARTMENT}

This book is due on the last date stamped below, or on the date to which renewed. Renewed books are subject to immediate recall.

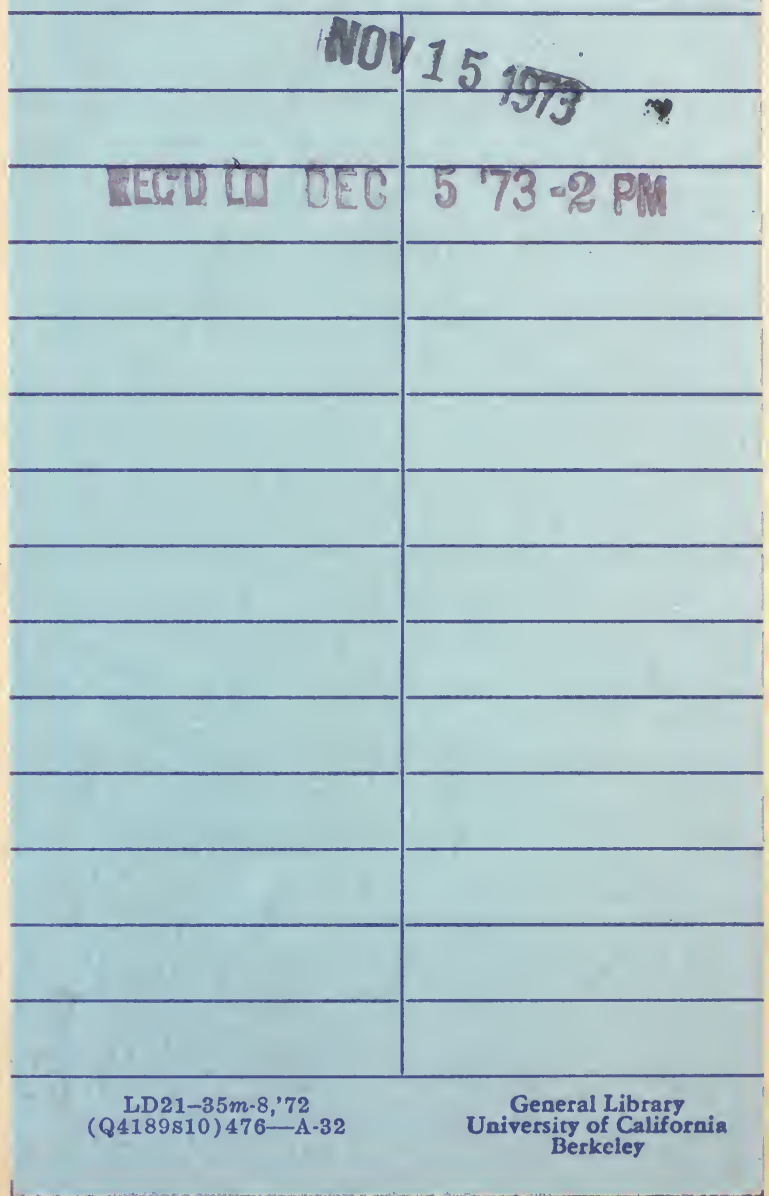



